


\section{EFFECTS OF RESIDENTIAL WASTEWATER-TREATMENT}

SYSTEMS ON GROUND-WATER QUALITY IN

WEST-CENTRAL JEFFERSON COUNTY, COLORADO

By Dennis C. Hall and Donald E. Hillier,

U.S. Geological Survey, and

Edward Nickum and William G. Dorrance,

Jefferson County Health Department

U.S. GEOLOGICAL SURVEY

Water-Resources Investigations

Open-File Report 81-73

Prepared in cooperation with the

JEFFERSON COUNTY HEALTH DEPARTMENT

Lakewood, Colorado

1931 
UNITED STATES DEPARTMENT OF THE INTERIOR

JAMES G. WATT, Secretary

GEOLOGICAL SURVEY

Doyle G. Frederick, Acting Director

For additional information

write to

Colorado District Chief

U.S. Geological Survey, MS 415

Box 25046, Denver Federal Center

Lakewood, C0 80225 
Abstract- Page

Introduction-

Approach-_.

Acknowl edgments-

Geohydrologic setting-- 4

Indicators of ground-water quality- 7

Dissolved solids-_at 7

Chloride, nitrite, and nitrate-1 7

Detergents- 8

Bacteria-nas 8

Ground-water quality-

Ground-water quality in the three communities-- 9

Marshdale-1

Herzman Mesa-cos 9

Evergreen Meadows-- 11

Comparison of ground-water quality in the three communities-_- 11

Estimating chemical quality of ground water in the three communities---- 11

Factors affecting ground-water quality-18

Age of community- 18

Average lot size-19 19

Slope of land surface-19

Fracture density, size, and orientation in the bedrock aquifer-.-.-. 19

Composition, permeability, and thickness of surficial material---.-- 19

Types and maintenance of residential wastewater-treatment systems--.-.-- 20

Use of fertilizers- 20

An ima ls--

Comparison between septic and aeration systems- 21

Data obtained for comparison- 21

Results of the comparison- 23

Summary-1

Selected references-

Supplemental data-1 35

\section{ILLUSTRATIONS}

Plate 1. Map showing geology and distribution of soil, bedrock, and alluvium in the vicinity of Marshdale, Herzman Mesa, and Evergreen Meadows, west-central Jefferson County, Colorado-- in pocket

2-4. Maps showing values of specific conductance, concentrations of dissolved chloride, and concentrations of dissolved nitrite plus nitrate in ground water:

2. Marshdale, west-central Jefferson County, Colorado---- In pocket

3. Herzman Mesa, west-central Jefferson County, Colorado- In pocket

4. Evergreen Meadows, west-central Jefferson County, Colorado- In pocket 


\section{CONTENTS}

Figure 1. Map showing location of study area-

2-4. Histograms showing:

2. Values of specific conductance in well water in Marshdale, Herzman Mesa, and Evergreen Meadows--.-.

3. Concentrations of dissolved chloride in well water in Marshdale, Herzman Mesa, and Evergreen Meadows--..--

4. Concentrations of dissolved nitrite plus nitrate in well water in Marshdale, Herzman Mesa, and Evergreen Meadows---

5-7. Graphs showing:

5. Relationship between concentrations of dissolved nitrite plus nitrate and dissolved chloride in well water from Marshdale, Herzman Mesa, and Evergreen Meadows---_-_---

6. Relationship between concentration of dissolved nitrite plus nitrate and specific conductance in well water from Marshdale, Herzman Mesa, and Evergreen Meadows----

7. Relationship between concentration of dissolved chloride and specific conductance in well water from Marshdale, Herzman Mesa, and Evergreen Meadows-...-.-.

8. Map showing location of septic and aeration systems where data were collected for use in comparing the two systems--.-.--

TABLES

Table 1. Summary of well data, Marshdale, Herzman Mesa, and Evergreen

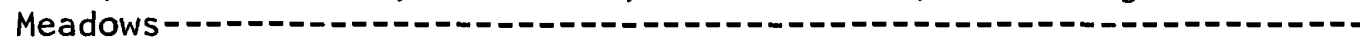

2. Summary of water-quality indicators in well water, Marshdale,
Herzman Mesa, and Evergreen Meadows-

2. Summary of water-quality indicators in well water, Marshdale,
Herzman Mesa, and Evergreen Meadows

3. Summary of chemical data used in the comparison of septic and aeration systems--...-.

4. Comparison between average concentrations of selected constituents in effluent from treatment tanks--.

5. Comparison between average concentrations of selected constituents in effluent from soil-absorption fields------

6. Analyses of selected constituents in well water-a

7. Supplemental data for sites listed in table 6-

8. Analyses of water from wells and effluent from treatment tanks and soil-absorption fields------

9. Analyses by the Jefferson County Department of Health of water from wells and effluent from treatment tanks and soil-absorption

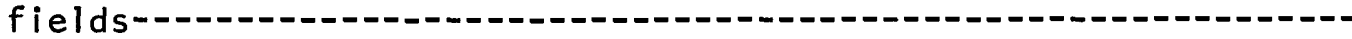

10. Supplemental data for sites where observation wells were installed in soil-absorption fields--- 


\section{METRIC CONVERSIONS}

Inch-pound units used in this report may be converted to metric units by use of the following conversion factors:

\section{Muztiply}

inch (in.)

foot $(f t)$

mile (mi)

square foot

acre

square mile $\left(\mathrm{mi}^{2}\right)$

gallon

gallon per minute
By

25.40

0.3048

1.609

0.0929

0.4047

2.590

3.785

0.06309
To obtain

millimeter

meter

kilometer square meter hectare

square kilometer

liter

liter per second 


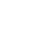




\title{
EFFECTS OF RESIDENTIAL WASTEWATER-TREATMENT SYSTEMS ON GROUND-WATER QUALITY IN WEST-CENTRAL JEFFERSON COUNTY, COLORADO
}

\author{
By Dennis C. Hall and Donald E. Hillier, U.S. Geological Survey \\ and
}

Edward Nickum and William G. Dorrance, Jefferson County Health Department

\section{ABSTRACT}

The use of residential wastewater-treatment systems in Evergreen Meadows, Marshdale, and Herzman Mesa has degraded ground-water quality to some extent in each community. Age of community; average lot size; slope of land surface; composition, permeability, and thickness of surficial material; density, size, and orientation of bedrock fractures; maintenance of wastewater-treatment systems; and presence of animals are factors possibly contributing to the degradation of ground-water quality.

Ground water in Evergreen Meadows, the youngest community and the community with the largest average lot size, is the least degraded and most suitable for use as a drinking-water supply. Ground water in Marshdale, the oldest community and the community with the smallest average lot size, is degraded to the degree that disinfection of the water to avoid bacterial contamination may be warranted in parts of the community. Ground water in Herzman Mesa is the most degraded and least suitable for use as a drinking-water supply. Bacterial contamination and excessive concentrations of dissolved nitrite plus nitrate are the major waterquality problems. Disinfection of the water to eliminate bacteria may be warranted in the community.

When compared with effluent from aeration-treatment tanks, effluent from septic-treatment tanks is characterized by greater biochemical oxygen demand and greater concentrations of detergents. When compared with effluent from septictreatment tanks, effluent from aeration-treatment tanks is characterized by greater concentrations of dissolved oxygen, nitrite, nitrate, sulfate, and dissolved solids.

Changes in the effluent in the aerobic soil-absorption fields associated with the two systems were: Biochemical oxygen demand and concentrations of detergents and sulfate decreased in both systems; concentrations of dissolved oxygen and nitrite increased in septic systems and decreased in aeration systems; concentrations of nitrate increased in both systems; and concentrations of dissolved solids remained about the same in septic systems and increased in aeration systems. 


\section{INTRODUCTION}

Increasing residential development and the resulting increase in the number of wells drilled for domestic water supplies and in the number of residential waste-treatment systems installed to dispose of domestic wastes are causing significant changes in the hydrology of the fractured crystalline-rock aquifer in west-central Jefferson County (fig. 1). In 1971, the U.S. Geological Survey began a 6-year, two-phase investigation of west-central Jefferson County to determine the effects of the increased development on the quality and quantity of water in the fractured crystalline-rock aquifer.

The first phase of the investigation, done in cooperation with the Jefferson County Planning Commission and the Colorado Geological Survey, was conducted to determine water availability, general water quality, and factors controlling water quality. Results of the first phase of the investigation (Hofstra and Hall, 1975a and 1975b) showed that the disposal of domestic wastes is causing degradation of ground-water quality and that radiochemicals in the water may pose a health risk.

In 1975, the U.S. Geological Survey, in cooperation with the Jefferson County Health Department, began the second phase of the investigation. One of the objectives of the second phase was to determine the effects of residential wastewatertreatment systems on ground-water quality by: (1) Comparing the ground-water quality in three communities that use residential wastewater-treatment systems, and (2) comparing the quality of wastewater effluent from septic-treatment and aeration-treatment systems. This report presents the results of this aspect of the second phase of the investigation.

The results of other aspects of the second phase of the investigation are presented in a report by Hall and Johnson (1979). Topics discussed in their report include: (1) The chemical and bacterial quality of water in the fractured crystalline-rock aquifer, (2) concentrations of trace elements and radiochemicals in ground water, (3) seasonal variations in ground-water quality, (4) the presence or absence of degradation in chemical quality during a 2-year period in extensively developed areas, and (5) the pattern and extent of fluctuation in water levels.

\section{Approach}

The effects on water quality of residential wastewater-treatment systems were determined by comparing ground-water quality in representative areas (about $0.25 \mathrm{mi}^{2}$ ) of three communities: Marshdale, Herzman Mesa, and Evergreen Meadows (fig. 1). These communities have similar geohydrologic settings and types of wastewater-treatment systems. Major differences between the representative areas were average lot size (1.2 acres in Marshdale, 1.9 acres in Herzman Mesa, and 3.5 acres in Evergreen Meadows) and age of the communities (Marshdale was subdivided in 1923, Herzman Mesa in 1946, and Evergreen Meadows in 1969). 


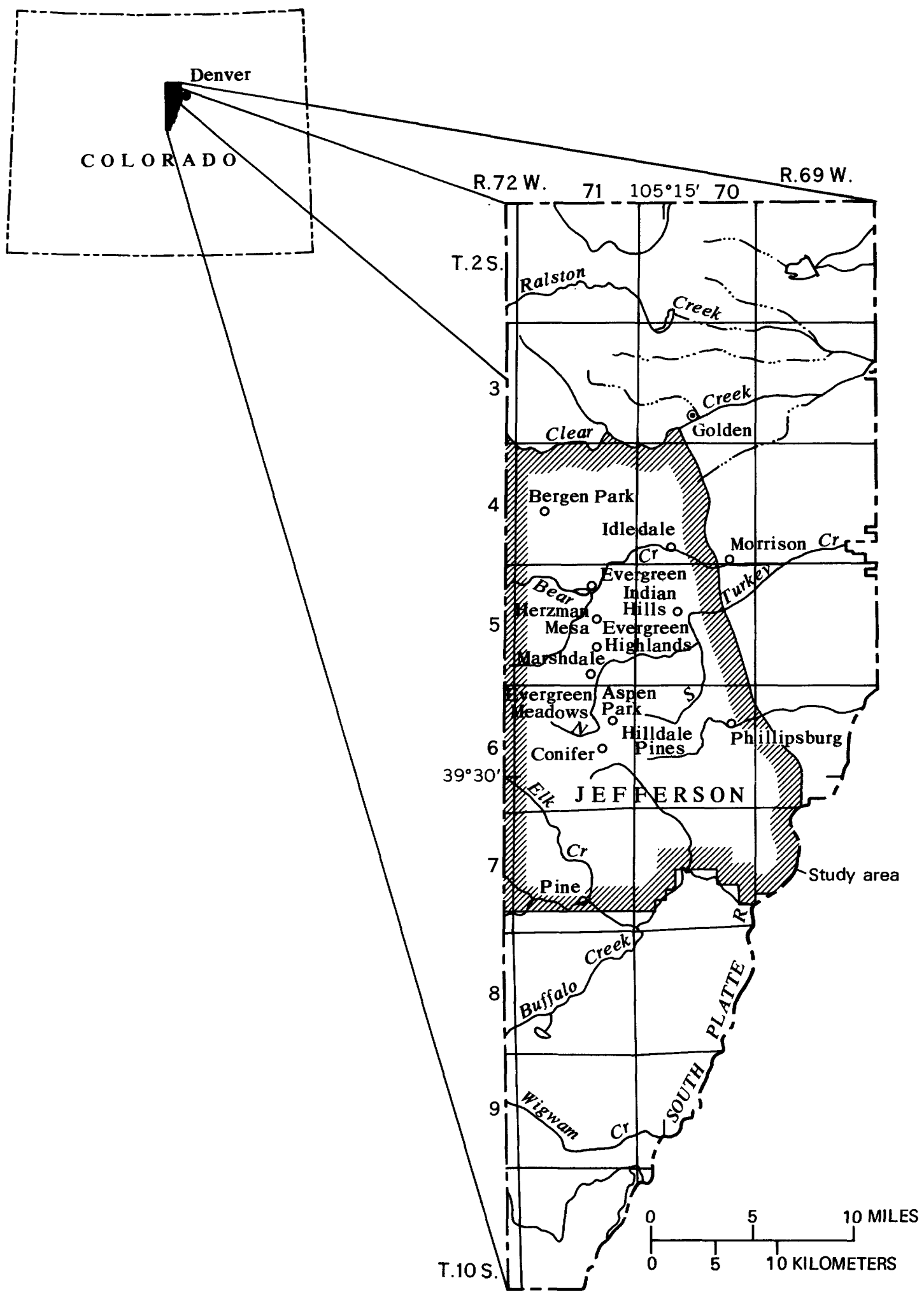

Figure 1.-- Location of study area. 
Samples for water-quality analyses were collected from about 30 wells in each of the three communities. The samples were analyzed for: Dissolved chloride, dissolved nitrite, dissolved nitrate, detergents, coliform bacteria, and fecalcoliform bacteria. For some samples, dissolved nitrite plus nitrate was determined rather than the individual constituents. In addition, the specific conductance of the water was measured at the time the water samples were collected.

Comparisons between residential wastewater-treatment systems were made using eight septic-treatment systems, two or three in each community, and seven aeration-treatment systems. Because few aeration systems had been installed in the three communities (only one, in Evergreen Meadows, was sampled in the three communities), aeration systems in other parts of west-central Jefferson County were used--Bergen Park (one system), Evergreen Highlands (one system), and Hilldale Pines (four systems) (fig. 1). At the site of each system, a test well was installed in the soil-absorption field and samples for water-quality analyses were collected from the test well, treatment tank, and the water-supply well. Most samples were analyzed for specific conductance and major chemical constituents. Selected samples were analyzed for bacteria, biochemical and chemical oxygen demand, detergents, dissolved oxygen, oil and grease, and turbidity.

Well-water samples were obtained from inside or outside faucets and placed in sterile containers, after water was discharged for a few minutes. Treatment-tank samples were dipped from the tank at the exit pipe and placed in sterile containers. Test-well samples were dipped from the wells in soil-absorption fields and placed in clean sample bottles.

\section{Acknowledgments}

Appreciation is extended to the landowners who permitted water samples to be collected and who allowed the installation of test wells on their property. Carl J. Johnson, Dan W. Tipton, and Richard A. Bell of the Jefferson County Health Department assisted in the planning and data-collection phases of the investigation. Well records were obtained from the files of the Colorado Department of Natural Resources, Division of Water Resources, Office of the State Engineer.

\section{GEOHYDROLOGIC SETTING}

Marshdale, Herzman Mesa, and Evergreen Meadows are located within a mountainous, $8-\mathrm{mi}^{2}$ area between Evergreen and Conifer in west-central Jefferson County (fig. 1) about $15 \mathrm{mi}$ southwest of Denver, Colo. The average altitude of the area is about $7,800 \mathrm{ft}$. The bedrock underlying the communities is migmatite that includes mostly gneiss and schist (Bryant, 1974) (pl. 1). Soil and weathered rock overlie the bedrock in most areas; however, alluvial deposits occur in stream valleys.

Most homeowners, who are permanent residents, obtain their water supplies from wells completed in the bedrock where it is fractured. A few domestic wells are completed in the alluvial deposits. Household wastes are usually treated in septic tanks and disposed of through leach fields installed in the soil and weathered bedrock or in the alluvial deposits. 
Unconsolidated surficial material is usually less than $10 \mathrm{ft}$ thick, and soil is poorly developed. Alluvial deposits found along stream valleys also are usually less than $10 \mathrm{ft}$ thick. Bedrock consists of nonporous granitic and metamorphic rocks. Water is present in and moves through fractures in the bedrock. The frequency of occurrence and width of the fractures decreases with depth. Recharge to the aquifer is from precipitation. The hydrologic surface generally follows the topographic surface. This generalization has been verified by preliminary potentiometric-surface maps constructed from well-drillers' records.

The altitude of Marshdale ranges from about 7,800 to $8,000 \mathrm{ft}$ and the average slope of the land surface is 17 percent, the greatest for the three communities. The distribution of soil, bedrock, and alluvium is shown on plate 1 . About 60 percent of the community is underlain by soil with subordinate rock (SR on pl. 1), about 35 percent by mostly rock (MR on pl. 1), and about 5 percent by alluvial soil (AL on $\mathrm{pl} .1$ ).

Drillers' records are available for 27 wells in Marshdale; the records are summarized in table 1 . Well depth and depth to water generally are greatest while well yield and thickness of surficial material (depth to bedrock) generally are least when compared with the other communities.

The altitude of Herzman Mesa ranges from about 7,600 to $7,800 \mathrm{ft}$ and the average slope of the land surface is 12 percent, which is less than that of Marshdale but greater than that of Evergreen Meadows. The distribution of soil, bedrock, and alluvium is shown on plate 1 . About 75 percent of the community is underlain by mostly soil (MS on $\mathrm{pl} .1$ ) and about 25 percent by soil with subordinate rock (SR on $\mathrm{pl}, 1$ ).

Drillers' records are available for 23 wells in Herzman Mesa and are summarized in table 1. Thickness of surficial material generally is greatest while well depth generally is least when compared with the other communities. Well yield generally is greater than in Marshdale but less than in Evergreen Meadows. Depth to water generally is greater than in Evergreen Meadows but less than in Marshdale.

The altitude of Evergreen Meadows ranges from about 7,800 to $8,000 \mathrm{ft}$ and the average slope of the land surface is 10 percent, the least for the three communities. The distribution of soil, bedrock, and alluvium is shown on plate 1 . About 85 percent of the community is underlain by mostly soil (MS on pl. 1) and about 15 percent by alluvial soil (AL on pl. 1).

Drillers' records are available for 18 wells in Evergreen Meadows and are summarized in table 1 . Well yield generally is greatest while depth to water generally is least when compared with the other communities. Well depth generally is greater than in Herzman Mesa but less than in Marshdale. Thickness of surficial material generally is greater than in Marshdale but less than in Herzman Mesa. 


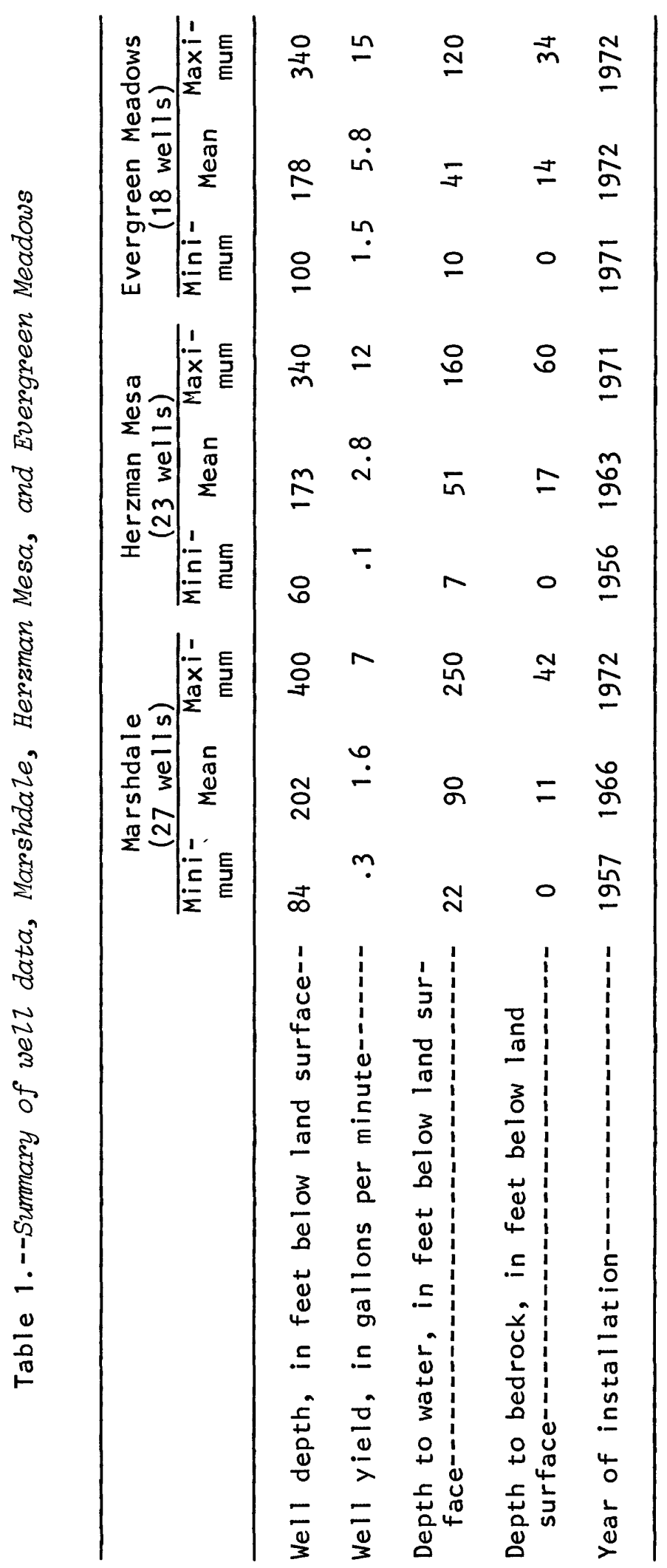




\section{INDICATORS OF GROUND-WATER QUALITY}

The presence in ground water of chemical and bacterial constituents that are major components of effluent from residential wastewater-treatment systems is an indication of the relative efficiency of the systems. Concentrations of dissolved solids (calculated from specific conductance), dissolved chloride, dissolved nitrite, dissolved nitrate, detergents, and coliform and fecal-coliform bacteria were the indicators used in this study.

\section{Dissolved Solids}

Degradation of water by effluent from residential wastewater-treatment systems commonly is indicated by increased concentrations of dissolved solids in the water. Results of studies in areas with geohydrologic settings similar to west-central Jefferson County (Klein, Goddard, and Livingston, 1978--Park and Teller Counties; Hall and others, 1979--Boulder County) and results of a previous study in Jefferson County (Hofstra and Hall, 1975a) indicate that ground water rarely will contain more than several hundred milligrams per liter of dissolved solids unless the water has been degraded by effluent from wastewater-treatment systems. Hofstra and Hall (1975a) determined that the dissolved-solids concentration in ground water in the study area may be estimated by multiplying specific conductance by 0.7 . Using this relationship, water with a specific conductance greater than 715 micromhos per centimeter at $25^{\circ}$ Celsius will probably contain more than $500 \mathrm{mg} / \mathrm{L}$ (milligrams per liter) of dissolved solids, which is the recommended standard for drinking water established by the U.S. Environmental Protection Agency (1977). Dissolved-solids concentrations greater than $500 \mathrm{mg} / \mathrm{L}$ may impart an unpleasant taste to the water but will ordinarily have no serious physiological effect on humans (McKee and Wolf, 1971).

\section{Chloride, Nitrite, and Nitrate}

Chloride, nitrite, and nitrate occur naturally in ground water in the area; however, natural concentrations of these constituents in ground water are relatively small. Large concentrations of these constituents in ground water indicate possible contamination of water supplies by human or animal wastes.

Chloride is chemically stable and generally remains in a soluble form both in effluent from wastewater-treatment systems and in ground water. In addition to being an indicator of contamination, concentrations of dissolved chloride exceeding the recommended standard of $250 \mathrm{mg} / \mathrm{L}$ for drinking water (U.S. Environmental Protection Agency, 1977) may impart a salty taste to the water (McKee and Wolf, 1971).

The contribution of nitrite and nitrate to ground water from aquifer materials is limited, except possibly from organic-rich shales (Goldberg, 1971), which are not found in the study area (Bryant, 1974). The contribution of nitrite and nitrate to ground water from commercial fertilizers probably is insignificant in the study area because there are few lawns and no large agricultural areas. 
Infiltrating wastewater is considered a major source of nitrite and nitrate in

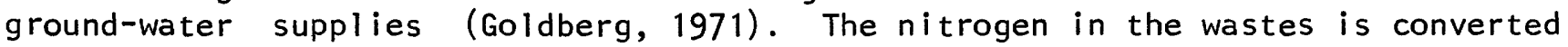
to nitrite and nitrate in the presence of oxygen and certain bacteria. Nitrite generally does not occur in large concentrations because it is oxidized to form nitrate. Concentrations of dissolved nitrate exceeding the mandatory standard of $10 \mathrm{mg} / \mathrm{L}$ for drinking water (Colorado Department of Health, 1977) may cause methemoglobinemia (blue-baby disease) in newborn infants who drink the water or who are breast fed by mothers who drink the water (McKee and Wolf, 1971). Although the mandatory standard of $10 \mathrm{mg} / \mathrm{L}$ is for dissolved nitrate only, concentrations of both dissolved nitrite and nitrate were determined because both can cause the same health problems.

\section{Detergents}

The presence of detergents (methylene blue active substances or MBAS) in ground water is a positive indication of contamination by domestic wastes because detergents do not occur naturally in water. Excessive concentrations of detergents may cause water to foam and may impart an unpleasant taste to the water (McKee and Wolf, 1971). The recommended standard for detergents in drinking water is $0.5 \mathrm{mg} / \mathrm{L}$ (U.S. Environmental Protection Agency, 1977).

\section{Bacteria}

The presence of coliform bacteria in ground water may indicate either fecal or nonfecal contamination of the water. Fecal-coliform bacteria, which occur most commonly in the intestines of humans and animals or in soils contaminated by human and animal wastes, in ground water indicate recent contamination by human or animal wastes. Drinking water containing fecal-coliform bacteria is considered a health hazard because pathogenic bacteria and viruses may be associated with these bacteria (McKee and Wolf, 1971).

Drinking-water standards for bacteria (Colorado Department of Health, 1977; U.S. Environmental Protection Agency, 1976b) are based on multiple tests of municipal supplies, but the Jefferson County Health Department routinely advises that samples containing more than 1 coliform bacterium per 100 milliliters may be unsafe, and that the presence of any fecal-coliform bacterium is unacceptable. When bacteria are present in a water supply, disinfection using chlorine usually is recommended or required by public-health officials. A single disinfection of the well may eliminate the bacteria, but in wells where continual contamination is occurring, installation of a chlorinator or some other type of disinfection system may be needed. In addition, inspection of the well is appropriate to verify that proper grouting and a sanitary seal are preventing contamination by surface runoff at the well site. 


\title{
Ground-Water Quality in the Three Communities
}

\author{
Marshdale
}

On the basis of specific-conductance values and chemical-constituent concentrations in water from 29 wells in the $0.25-\mathrm{mi}^{2}$ area of Marshdale, chemical concentrations increased downgradient to the southwest ( $p 1.2)$. The most degraded ground water occurs along State Highway 73. The pattern of increasing chemical concentrations generally reflects the movement of water in the aquifer, concentrations being least at the higher altitudes and greatest at the lower altitudes.

Although ground water in the area contains increased concentrations of bacterial and chemical indicators, the summary of water-quality data (table 2) indicates that there are few water-quality problems severe enough to affect the suitability of the water for use as a drinking-water supply. The maximum dissolved-solids concentration, based on specific conductance, was about $300 \mathrm{mg} / \mathrm{L}$. Concentrations of dissolved chloride, dissolved nitrite plus nitrate, and detergents were all less than drinking-water standards. Bacterial contamination is the most serious problem in the area. Coliform bacteria were present in water from wells 202 and 235 (see pl. 2 for well locations), and both coliform and fecalcoliform bacteria were present in water from well 225. Because these wells are located more than $1,000 \mathrm{ft}$ from each other interspersed with many wells without coliform bacteria, it is evident that the bacterial contamination is a localized rather than a widespread problem. Only well 225 is located in the area where water-quality degradation is greatest. Disinfection of the water should eliminate the bacterial-contamination problems.

\section{Herzman Mesa}

On the basis of specific-conductance values and chemical-constituent concentrations in water from 30 wells in the $0.25-\mathrm{mi}^{2}$ area of Herzman Mesa, water is least suitable for drinking in the north-central and northwestern parts of the area ( $\mathrm{pl}$. 3). The pattern of constituent-concentration increases is more random than in Marshdale. Altitude and direction of water movement in the aquifers do not appear to be as important in affecting the values or concentrations and distribution of constituents as they were in Marshdale.

In Herzman Mesa the maximum dissolved-solids concentration, based on specific conductance, was about $375 \mathrm{mg} / \mathrm{L}$ (table 2). Although concentrations of dissolved chloride did not exceed the drinking-water standard, concentrations of dissolved nitrite plus nitrate exceeded the Colorado drinking-water standard in water from wells 114,120 , and 124 (see pl. 3 for well locations), which are located in the north-central or northwestern parts of the area, and detergents exceeded the drinking-water standard in water from well 109. Coliform bacteria were present in water from wells 109 and 140. Again disinfection of the water should eliminate the bacterial-contamination problems. 


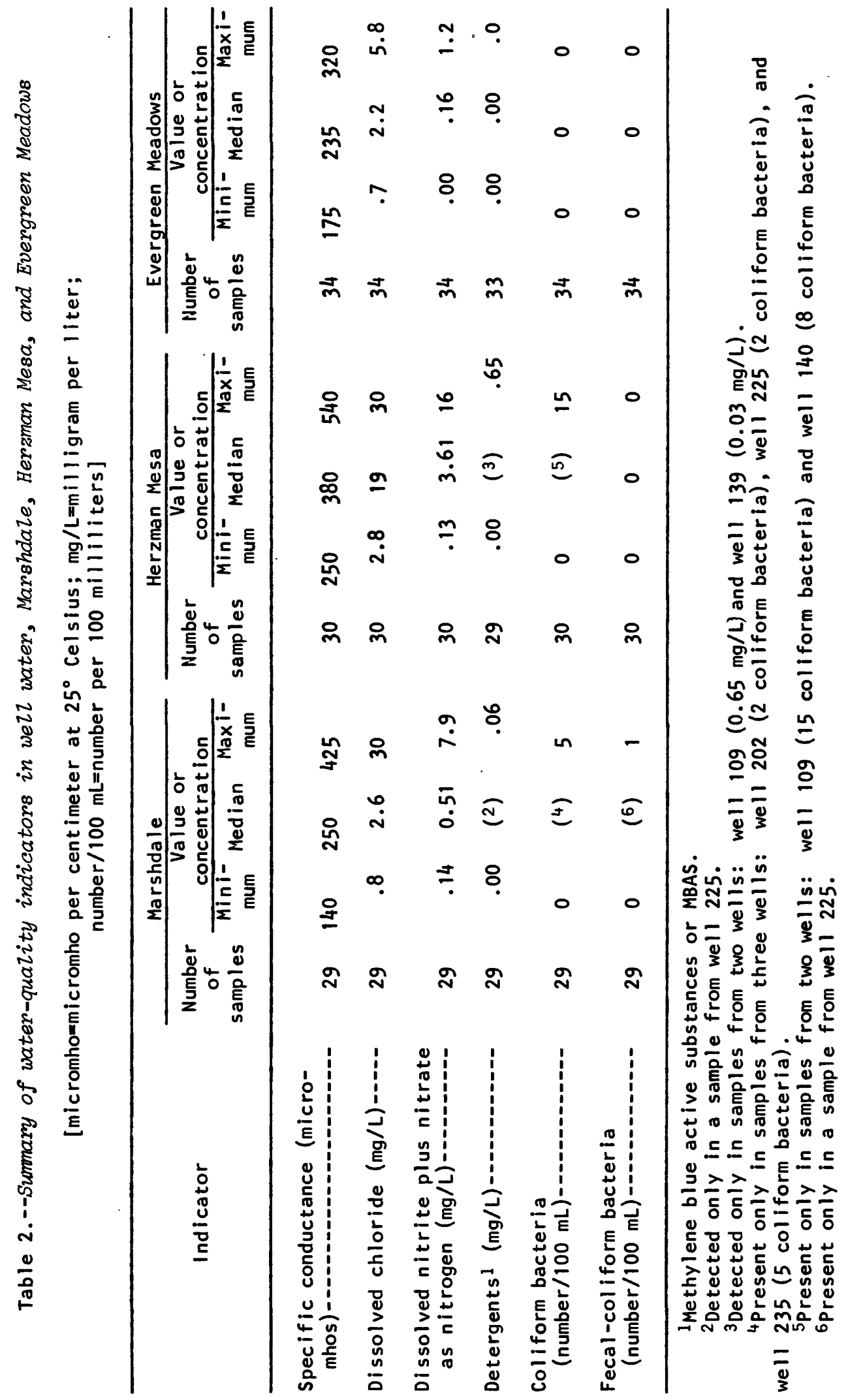




\section{Evergreen Meadows}

On the basis of specific-conductance values and chemical-constituent concentrations in water from 34 wells in the $0.25-\mathrm{mi}^{2}$ area of Evergreen Meadows, water is least suitable for drinking in the central part of the area (pl. 4). The pattern of chemical-constituent increases generally parallels the eastward-trending valley that bisects the area and reflects movement of water in the aquifer, chemical concentrations being least at the higher altitudes and greatest at the lower altitudes. The greater amount of chemical concentrations on the north slope of the valley is due to the greater housing density on this slope.

In Evergreen Meadows the maximum dissolved-solids concentration, on the basis of specific conductance, was about $225 \mathrm{mg} / \mathrm{L}$ (table 2). The concentrations of all chemical constituents were less than Colorado or U.S. Environmental Protection Agency drinking-water standards. No bacteria were present in water from any well.

\section{Comparison of Ground-Water Quality in the Three Communities}

The differences in ground-water quality in the $0.25-\mathrm{mi}^{2}$ areas of the three communities are shown graphically using specific-conductance values (fig. 2), concentrations of dissolved chloride (fig. 3), and concentrations of dissolved nitrite plus nitrate (fig. 4). Based on these data as well as bacterial data in table 2, ground water in Evergreen Meadows has the best quality and is the most suitable for use as a source of drinking-water supplies. Disinfection of the water before use probably is not warranted at this time (1979). Ground water in Marshdale may require disinfection before use as a drinking-water supply, particularly in the area immediately northeast of State Highway 73. Ground water in Herzman Mesa is the least suitable for use as a drinking-water supply, especially in the north-central and northwestern parts of the area because concentrations of dissolved nitrite plus nitrate exceeded $10 \mathrm{mg} / \mathrm{L}$ as nitrogen and fecal-coliform bacteria were present in the water. Ground water throughout Herzman Mesa may require disinfection before use as drinking water. Concentrations of dissolved nitrite plus nitrate exceeding $10 \mathrm{mg} / \mathrm{L}$ as $\mathrm{nitrogen}$ in the ground water could be a health hazard to infants (McKee and Wolf, 1971), and are an indication that inspection and cleaning of wastewater-treatment systems may be warranted. Proper regular maintenance of the entire treatment system--tank and leach field--wili aid in maintaining or improving ground-water quality in all the communities.

\section{Estimating Chemical Quality of Ground Water in the Three Communities}

The specific-conductance values and chemical- and bacterial-constituent concentrations in the $0.25-\mathrm{mi}^{2}$ parts of the communities may be indicative of waterquality conditions throughout the three communities. The chemical ground-water quality in parts of the communities that were not included in this investigation may be determined using relationships between dissolved nitrite plus nitrate and dissolved chloride (fig. 5), between dissolved nitrite plus nitrate and specific conductance (fig. 6), and between dissolved chloride and specific conductance (fig. 7). The relationships were developed using a linear least-squares method to determine the line of best fit on the basis of the data obtained during this investigation. 

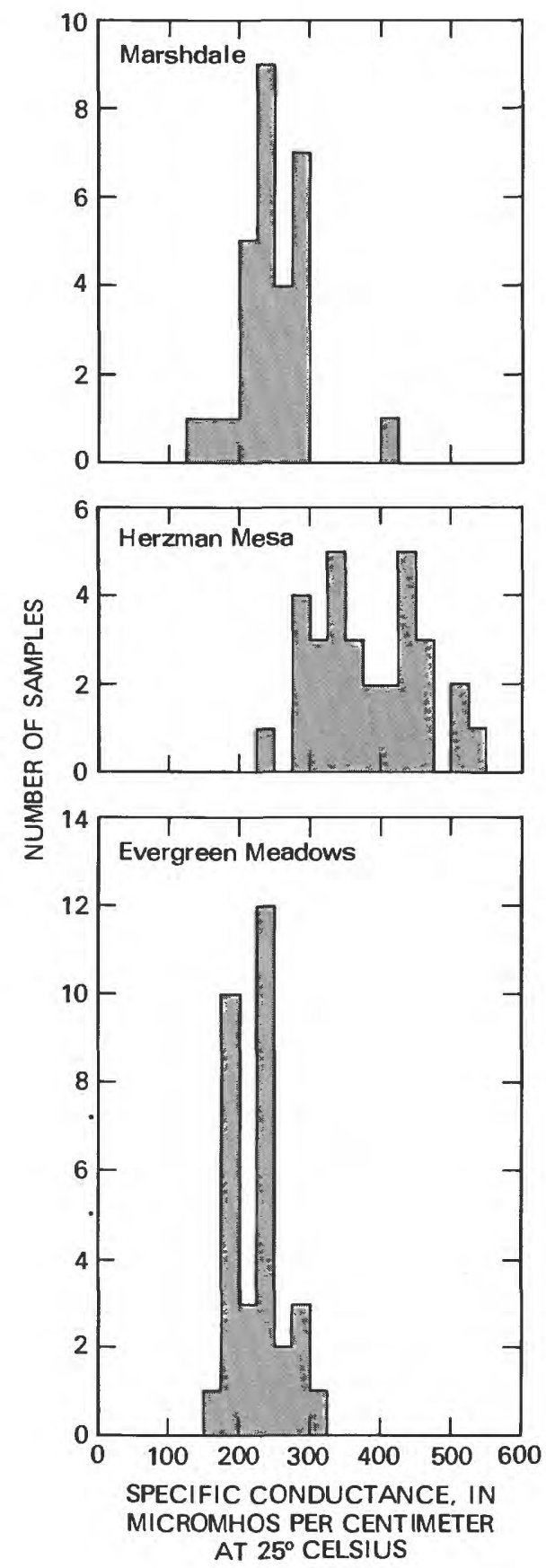

Figure 2.-- Values of specific conductance in well water in Marshdale, Herzman Mesa, and Evergreen Meadows. 

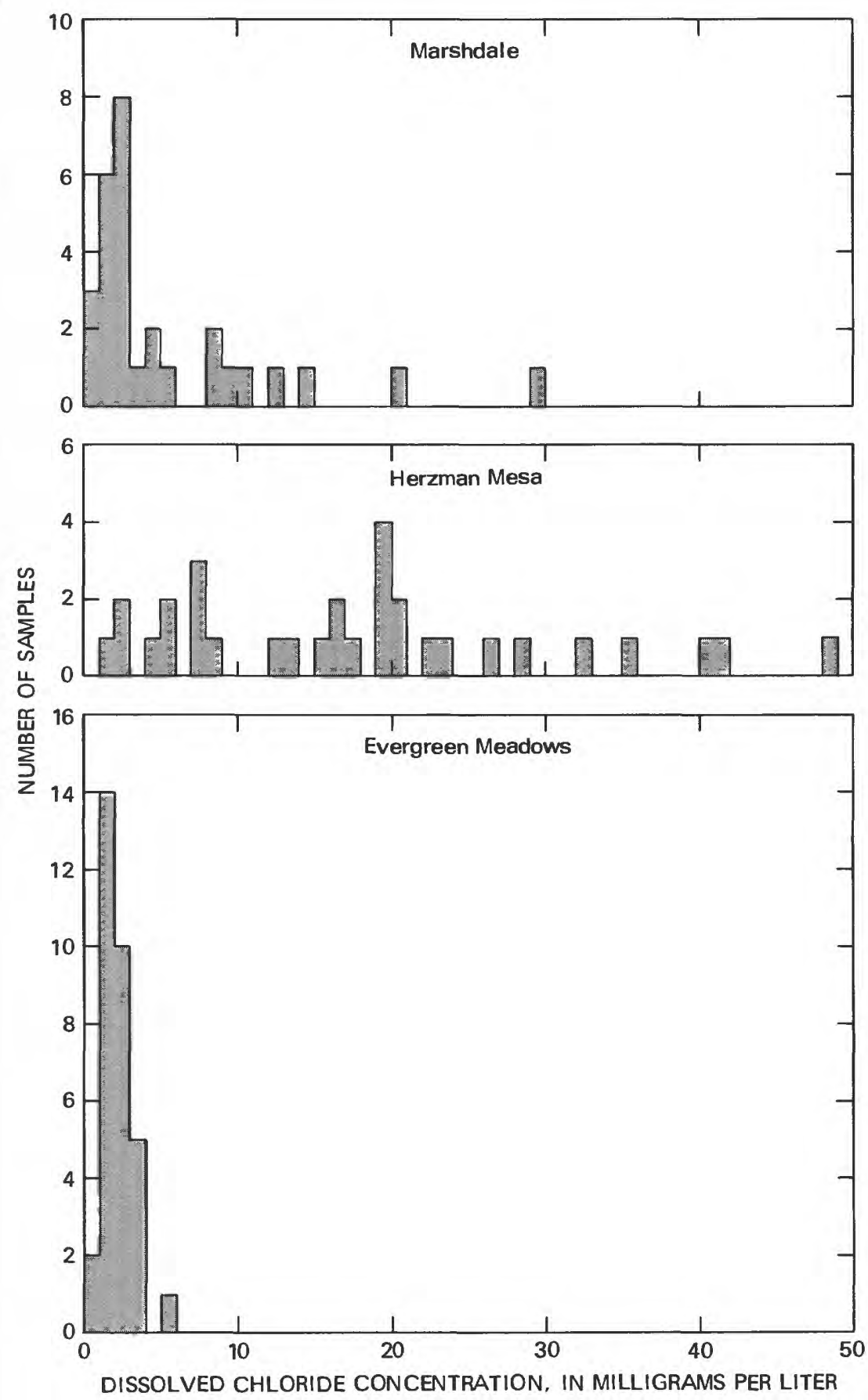

Figure 3.--Concentrations of dissolved chloride in well water in Marshdale, Herzman Mesa, and Evergreen Meadows. 

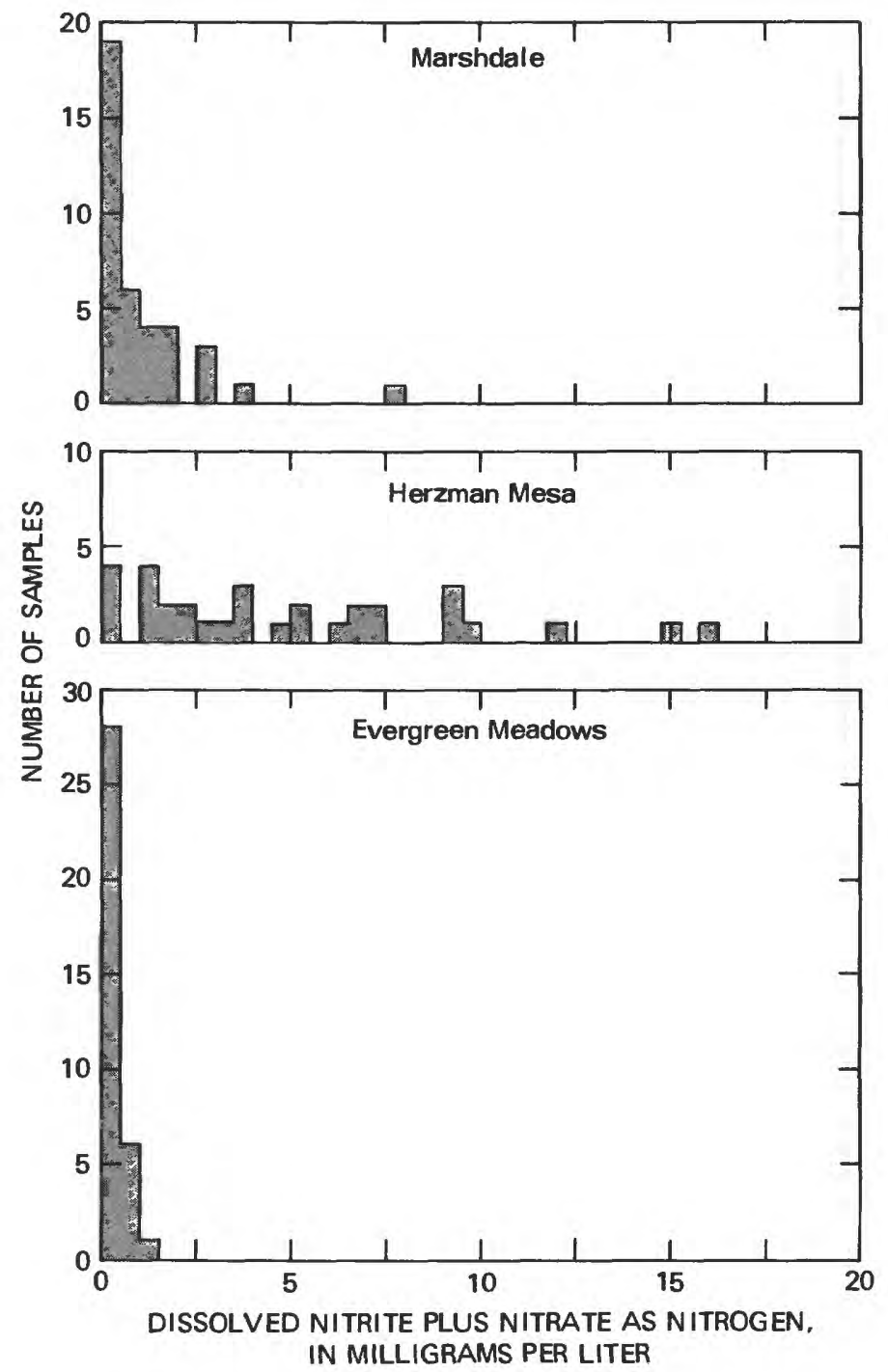

Figure 4..- Concentrations of dissolved nitrite plus nitrate in well water in Marshdale, Herzman Mesa, and Evergreen Meadows. 


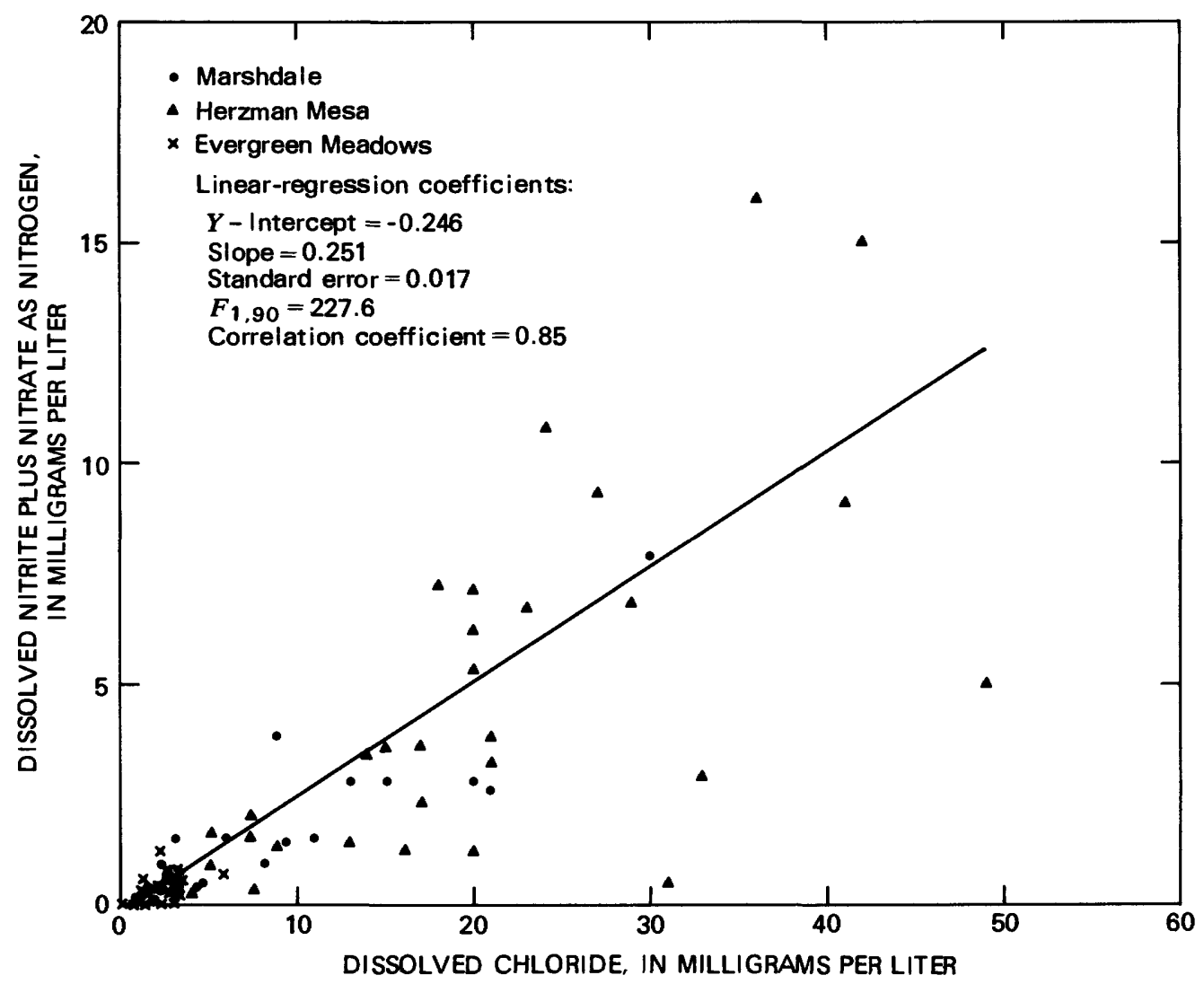

Figure 5.-- Relationship between concentrations of dissolved nitrite plus nitrate and dissolved chloride in well water from Marshdale, Herzman Mesa, and Evergreen Meadows. 


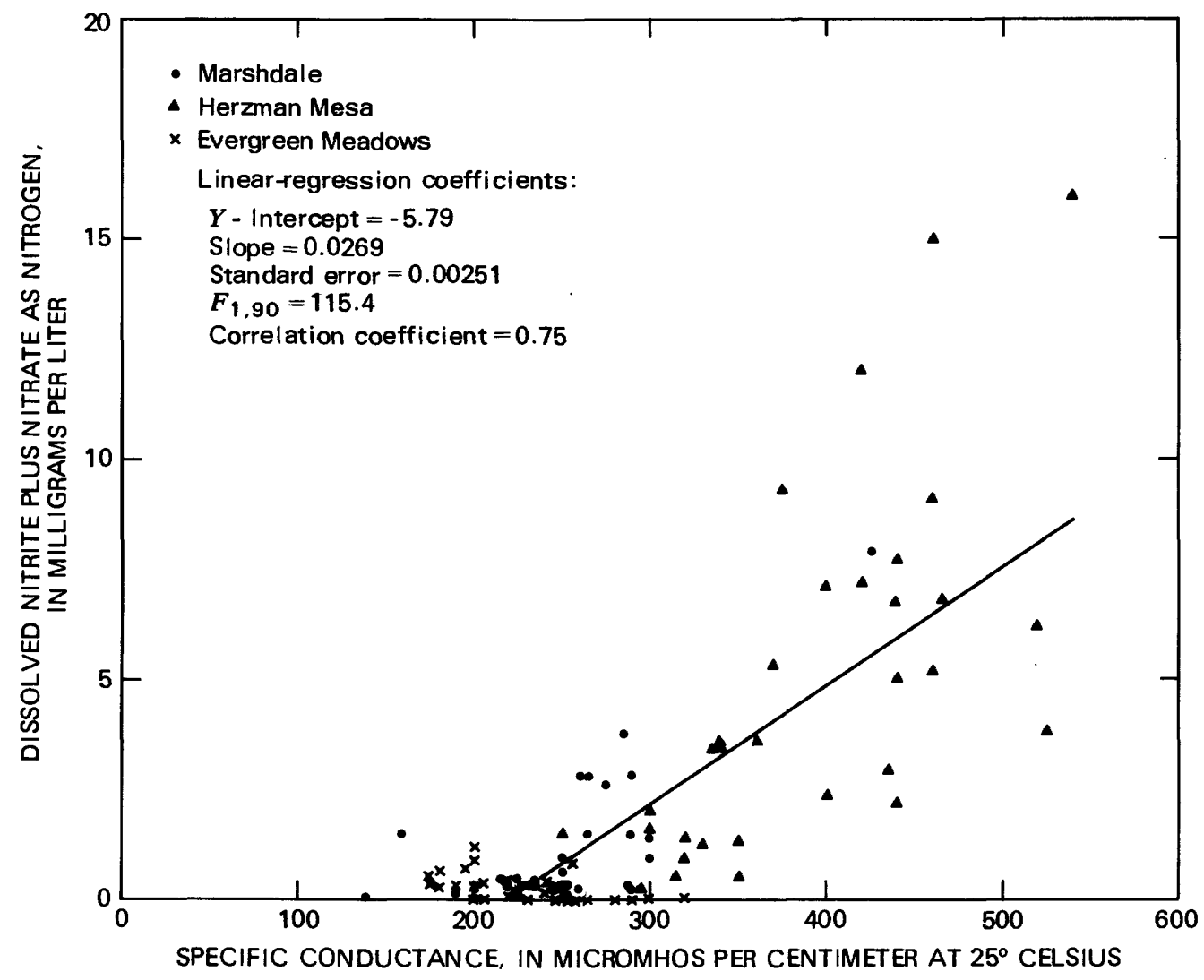

Figure 6.-- Relationship between concentration of dissolved nitrite plus nitrate and specific conductance in well water from Marshdale, Herzman Mesa, and Evergreen Meadows. 


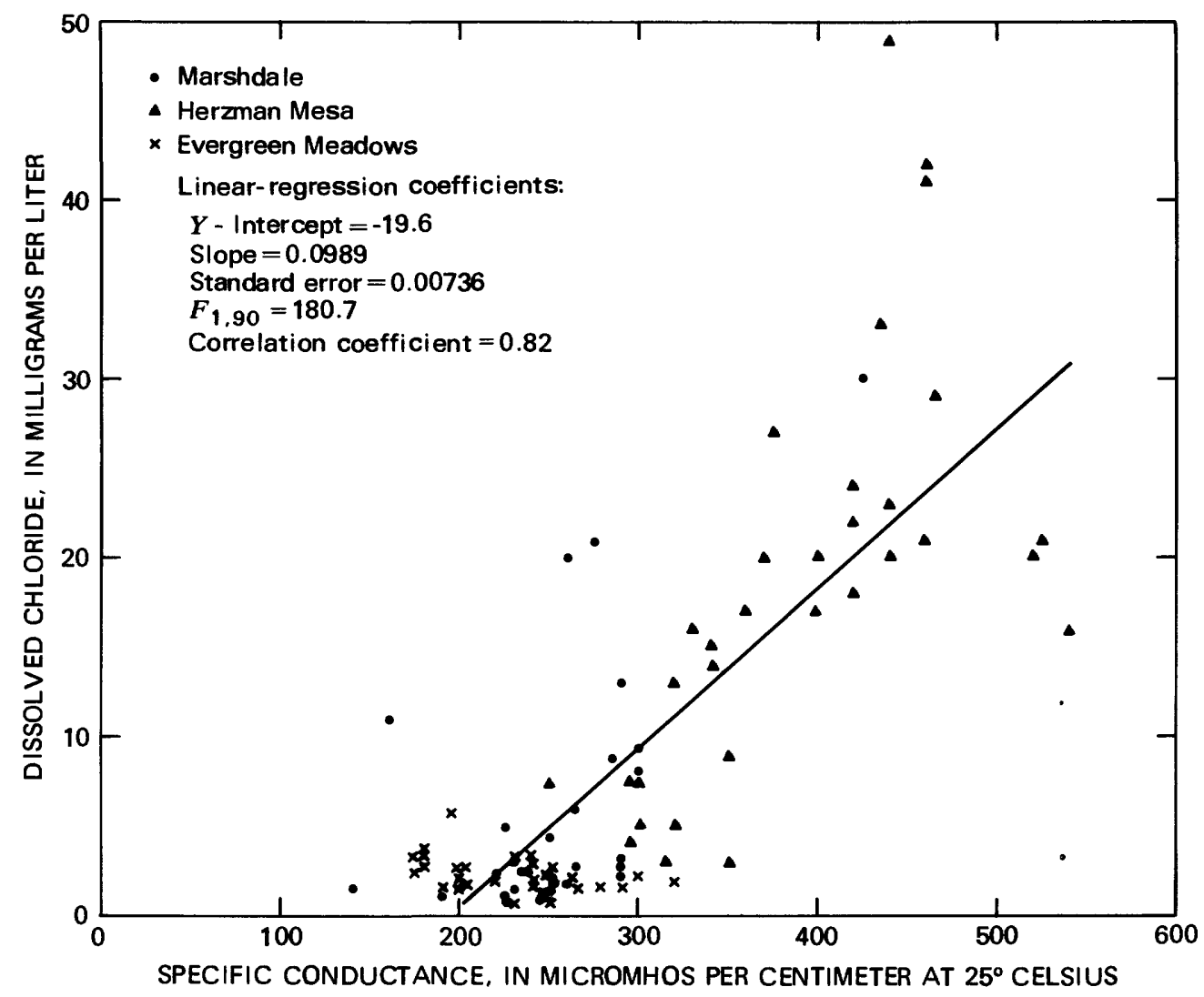

Figure 7.- Relationship between concentration of dissolved chloride and specific conductance in well water from Marshdale, Herzman Mesa, and Evergreen Meadows. 
If the concentration of dissolved chloride is known in water from a well, then, using the relationship in figure 5, an estimate of the dissolved nitrite plus nitrate in the water can be made. On the basis of the relationship in figure 5 , the concentration of dissolved nitrite plus nitrate as nitrogen probably will be greater than the Colorado drinking-water standard of $10 \mathrm{mg} / \mathrm{L}$ when the concentration of dissolved chloride is greater than $32 \mathrm{mg} / \mathrm{L}$.

If the specific conductance of well water is known, then the relationships in figures 6 and 7 may be used to estimate the concentration of dissolved nitrite plus nitrate or dissolved chloride in the water. Based on the relationship in figure 6 , the concentration of dissolved nitrite plus nitrate as nitrogen will probably be greater than $10 \mathrm{mg} / \mathrm{L}$ when specific conductance is greater than 455 micromhos.

\section{FACTORS AFFECTING GROUND-WATER QUALITY}

Factors that can affect ground-water quality in the three communities include: Age of community; average lot size; slope of land surface; fracture density, size, and orientation in the bedrock aquifer; composition, permeability, and thickness of surficial material; types and maintenance of residential wastewatertreatment systems; use of fertilizers; and the presence of animals such as horses and other livestock. Few data are available to evaluate the factors with respect to existing (1975) ground-water quality in the three communities. Therefore the discussions of the factors generally are limited to descriptions of how the factors may affect ground-water quality in the three communities.

\section{Age of Community}

Because increasing chemical concentrations in ground water resulting from residential wastewater-treatment systems are cummulative, the age of a community generally can be correlated to water quality. Ground water in older communities, such as Marshdale (subdivided during 1923) and Herzman Mesa (subdivided during 1946), generally contains greater chemical concentrations than in younger communities, such as Evergreen Meadows (subdivided during 1964). At some time after development has stabilized, chemical concentrations and specific conductance in ground water also should tend to stabilize. The time required to reach this level would be related to the rate of addition of contaminants and to the rates of natural and artificial recharge and discharge.

Additionally, homes in older communities tend to be smaller, have fewer bathrooms, and have fewer water-using appliances, such as automatic dishwashers and garbage disposals. The use of these appliances adds a significant load to wastewater-treatment systems (Bennett and Linstedt, 1975). Also, the size of families tends to be smaller in older communities. The combination of more waste-producing facilities and appliances and larger families generally results in larger volumes of wastes being discharged into the ground-water system in younger communities. 
Average lot size is directly related to the density of homes (population) and residential wastewater-treatment systems. Generally, the greater the density of treatment systems, the greater the volume of effluent being discharged into the ground-water system. The average lot size in the three communities is 1.2 acres in Marshdale, 1.9 acres in Herzman Mesa, and 3.5 acres in Evergreen Meadows.

\section{Slope of Land Surface}

Movement of water through the fractured bedrock aquifer is related to the slope of the land surface. Assuming that the aquifer characteristics are similar throughout an area, the greater the slope, the faster the movement of water through the aquifer. If the fracture density, size, and orientation vary within an area, both slope and fracture characteristics would affect the rate of movement. Generally, the rate of movement would be faster through a densely fractured aquifer on steep slopes and slower through a sparsely fractured aquifer on gentle slopes. The concentrations of chemical constituents should be greatest where ground water moves the slowest. The average slopes in the three communities are 17 percent in Marshdale, 12 percent in Herzman Mesa, and 10 percent in Evergreen Meadows.

Fracture Density, Size, and Orientation in the Bedrock Aquifer

Fracture density, size, and orientation affect the amount of water in storage in the bedrock aquifer and local patterns of water movement through the aquifer. Studies of individual home sites in Jefferson, Boulder, and Larimer Counties by Waltz (1972a) indicate the importance of fracture orientation in pollution of well water by effluent from adjacent residential wastewater-treatment systems. Detailed mapping of fractures in the three communities is not available. However, no large fracture zones occur in the three communities ( $p 1.1)$.

\section{Composition, Permeability, and Thickness of Surficial Material}

The surficial materials are a natural filter, interact chemically with effluent from wastewater-treatment systems, and affect the environment needed for bacterial growth. Thick, less permeable material increases the traveltime required for effluent from waste-disposal fields to reach bedrock or the water table. Longer traveltimes allow more time for occurrence of chemical reactions, such as decomposition of organic compounds or nitrate formation. On the other hand, slow movement of ground water also permits greater buildup of pollutants, such as nitrate or chloride, by concentration due to evapotransporation or by enrichment during reuse and redisposal of water in the area. 
Less permeable or fine-grained material also increases the removal by filtration of suspended material, including bacteria. Concentrations of coliform bacteria tend to increase in the upper few millimeters in fine-grained material because the bacteria attach themselves to soil particles and reproduce or survive longer. However, fecal-coliform bacteria, which die off rapidly outside their human or animal hosts, do not usually live more than 1 or 2 weeks (Geldreich, 1972; Gordon, 1972).

Generally, water will move into and through coarse-grained materials more rapidly than into and through fine-grained materials. According to Schmidt (1976), the coarsest surficial materials occur in Marshdale (60 percent soil with subordinate rock, 35 percent mostly rock, and 5 percent alluvial soil), the finest in Evergreen Meadows ( 85 percent mostly soil and 15 percent alluvial soil), and a mixture in Herzman Mesa (75 percent mostly soil and 25 percent soil with subordinate rock).

Thickness of surficial material affects the amount of filtration that occurs, as water, including effluent from wastewater-treatment systems, percolates through the unsaturated zone. The greater the thickness of surficial material overlying the fractured bedrock aquifer, the greater the possibility for more complete filtration. On the basis of drillers' records, the greatest mean thickness of surficial material occurs in Herzman Mesa $(17 \mathrm{ft}$ ), the least in Marshdale (11 $\mathrm{ft}$ ), and intermediate in Evergreen Meadows $(14 \mathrm{ft})$.

\section{Types and Maintenance of Residential Wastewater-Treatment Systems}

All three communities have similar types of residential wastewater-treatment systems--septic tanks with soil-absorption fields or leaching wells; therefore the type of system is not a factor affecting differences in ground-water quality between the communities. However, maintenance of the systems probably is a factor, based on the conditions of several septic tanks that were observed during the investigation. While obtaining data for the purpose of comparing septic-tank and aeration-tank systems, several sludge-filled septic tanks were observed. Wastes in these systems were moving directly from the homes, through the tanks, and into the soil-absorption fields with little or no treatment. Lack of proper maintenance of the tanks and soil-absorption fields can significantly affect ground-water quality. The "backing up" of wastes into homes or the ponding of effluent in the vicinity of the soil-absorption fields are indications of lack of maintenance. Periodic cleaning of tanks is needed to keep the systems functioning properly and to lessen the adverse effects on ground-water quality.

\section{Use of Fertilizers}

Farming is not important in the study area because tillable land is scarce and the growing season is short. Grass meadows are present along stream valleys and are used predominantly as horse pasture and occasionally for cattle. Commercial fertilizers are not commonly used in the study area. Consequently, contamination of ground water by nutrients from fertilizers is an uncommon occurrence. 
Animals

Livestock, particularly horses, and other animals are often kept near dwellings in the study area. When these animals are confined near a well site, as is often the case, the possibility exists for contamination by coliform bacteria, fecal-coliform bacteria, and nutrients. Just as soil-absorption fields should be located some distance from a well, animals and their wastes should also be kept away from the area near the well site.

\section{COMPARISON BETWEEN SEPTIC AND AERATION SYSTEMS}

Aerobic waste-treatment systems have been installed infrequently in Jefferson County, and performances of these units have been inadequately studied under the conditions prevalent in the area. In order for regulating agencies to better judge if aerobic systems are appropriate as waste-treatment systems in the mountains, more data pertaining to waste-degradation efficiencies are required. Septic systems predominate in the area and for this reason were used for comparison.

Septic systems function in the absence of oxygen (anaerobically). In contrast, aeration systems function with a continual supply of oxygen (aerobically) obtained from the air. Digestion of wastes by bacteria under aerobic conditions is more complete than digestion under anaerobic conditions. The end products of digestion under aerobic conditions generally are simple chemical constituents such as carbon dioxide and water, which are not toxic to bacteria. The end products of digestion under anaerobic conditions generally are complex chemical constituents, such as acids, which may limit further bacterial growth if they accumulate.

\section{Data Obtained for Comparison}

Data were obtained from eight septic systems and seven aeration systems. All the septic systems were located in Marshdale, Herzman Mesa, or Evergreen Meadows ( $f$ ig. 8 ). Because of the lack of aeration systems in the three communities, data were obtained from one aeration system in Evergreen Meadows, one system in Bergen Park, one system in Evergreen Highlands, and four systems in Hilldale Pines (fig. 8).

Observation wells, drilled with a power auger, were installed in the soilabsorption fields or sand filters at each site. In all instances, bedrock was reached at depths of less than $10 \mathrm{ft}$. Four-inch plastic casings with slots in the lower 18 to $24 \mathrm{in}$. were placed in the holes. Where possible, the top of the slotted part of the casing was placed $4 \mathrm{ft}$ below the distribution pipes in the soil-absorption fields. A gravel pack was installed outside of the slotted part of the casing and a bentonite seal installed above the gravel pack. The remaining annular space was then filled with dirt. 

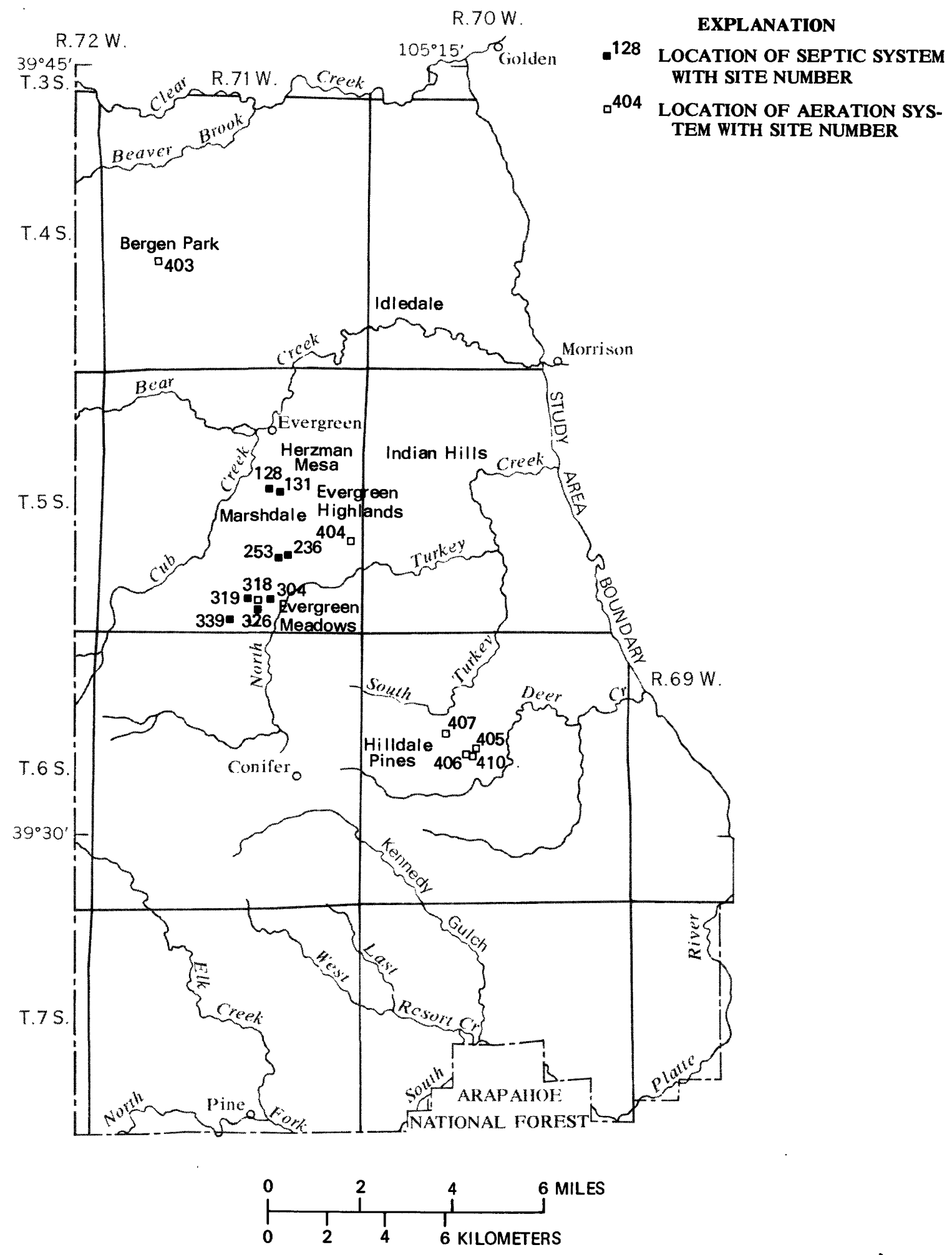

Figure 8.-- Location of septic and aeration systems where data were collected for use in comparing the two systems. 
Samples of water from the water-supply wells and samples of effluent from the treatment tanks and observation wells were collected for analysis. These samples were taken after the observation well had been in place for several weeks. Samples were obtained from five observation wells associated with septic systems and from two observation wells associated with aeration systems. Analytical results used in the comparison of the two systems are summarized in table 3 . Complete analytical results are presented in tables 8 and 9 at the end of the report.

\section{Results of the Comparison}

Chemical constituents in effluent from septic and aeration tanks (table 3) were compared by first determining how much each constituent was increased or decreased in the different treatment tanks with respect to the concentration of the constituent in water from the water-supply well. The resulting values were compared to determine how much greater the average concentration in one system would be than the average concentration in the other system. A step-by-step explanation of the method used is presented below using dissolved sulfate as an example:

Step 1: Determine the increase or decrease in average sulfate concentration in a typical septic tank: (a) Average sulfate concentration in well water=8.9 mg/L; (b) average sulfate concentration in septic-tank effluent $=24.9 \mathrm{mg} / \mathrm{L}$; and (c) increase in average sulfate concentration in septic-tank effluent is $16.0 \mathrm{mg} / \mathrm{L}$ (24.9-8.9).

Step 2: Determine the increase or decrease in average sulfate concentration in a typical aeration tank: (a) Average sulfate concentration in well water $=10.2 \mathrm{mg} / \mathrm{L}$; (b) average sulfate concentration in aeration-tank effluent $=61.9 \mathrm{mg} / \mathrm{L}$; and (c) increase in average sulfate concentration in aeration-tank effluent is $51.7 \mathrm{mg} / \mathrm{L}$ $(61.9-10.2)$.

Step 3: Compare increases in average sulfate concentrations in the two systems: Increase in average sulfate concentration was about 3.2 times $(51.7 \div 16.0)$ greater in aeration-tank effluent than in septic-tank effluent.

EXAMPLE: If the dissolved-sulfate concentration in well water were $5 \mathrm{mg} / \mathrm{L}$ and the water, after use, were disposed of using a septic system, the dissolvedsulfate concentration would be about $21 \mathrm{mg} / \mathrm{L}(5+16)$ in the septic-tank effluent. If the same well water, after use, were disposed of using an aeration system, the dissolved-sulfate concentration would be about $57 \mathrm{mg} / \mathrm{L}(5+51.7)$ in the aeration-tank effluent.

Results of the comparisons for effluent from treatment tanks are presented in table 4. The results are consistent with the methods by which the two systems function. Anaerobic treatment of wastes in septic tanks is characterized by greater biochemical oxygen demand and greater concentrations of detergents resulting from incomplete biological digestion of wastes. Aerobic treatment of wastes in aeration tanks is characterized by greater concentrations of dissolved oxygen, greater concentrations of oxidized products (nitrite, nitrate, and sulfate) that are produced during the biological digestion of wastes, and greater concentrations of dissolved solids resulting from evaporation and more complete oxidation to end products. 


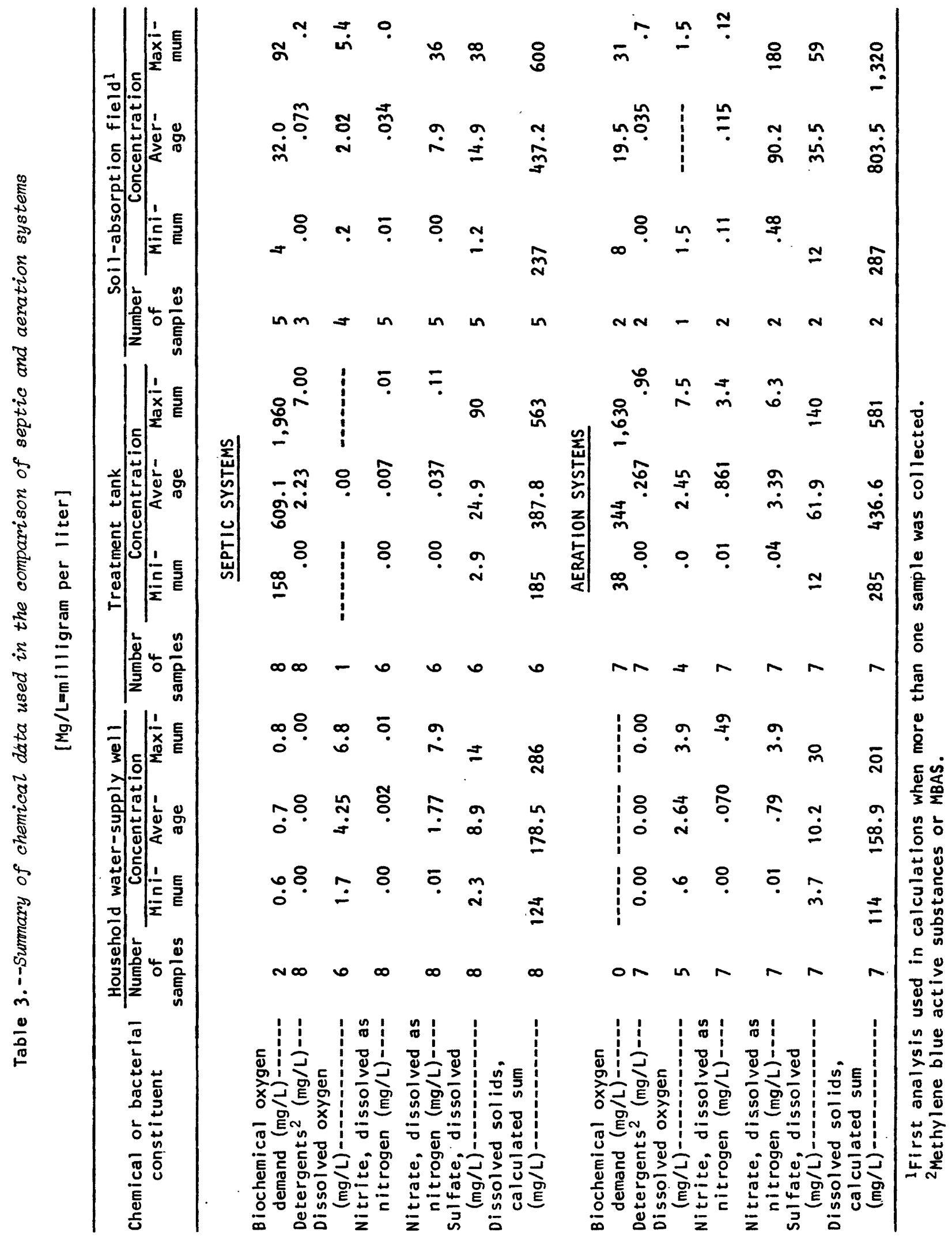


Table 4.--Comparison between average concentrations of selected constituents in effluent from treatment tanks

Change in average concentration in effluent with

Constituent respect to average concentration in well water Septic tank Aeration tank
Comparison of increase or decrease of average concentrations in effluent

\section{Biochemical oxygen}

demand--.--_..-..- Increase

Detergents-- Increase

Dissolved oxygen----- Decrease

Nitrite, dissolved---- Increase

Nitrate, dissolved-.-- Decrease ${ }^{1} \quad$ Increase $^{2}$

Sulfate, dissolved-.-- Increase Increase

Dissolved solids---.- Increase Increase
Increase

Decrease

Increase

Increase
Increase was about 1.8 times greater in septic-tank effluent.

Increase was about 8.4 times greater in septic-tank effluent.

Decrease was about 47 times greater in septic-tank effluent.

Increase was about 160 times greater in aeration-tank effluent.

Increase was about 3.2 times greater in aeration-tank effluent.

Increase was about 1.3 times greater in aeration-tank effluent.

${ }^{1}$ Average concentration in effluent will decrease about 58 times.

${ }^{2}$ Average concentration in effluent will increase about 4.3 times. 
The effluent from soil-absorption fields associated with the two systems also was compared. Ideally, because the soil-absorption fields function as aerobic systems, the following changes in the characteristics of the effluent from the two systems should occur:

1. Biochemical oxygen demand should decrease in both systems because of the additional oxygen available for use by bacteria. The decrease should be greater in septic systems because of the change from anaerobic conditions in treatment tanks to aerobic conditions in soil-absorption fields. However, the biochemical oxygen demand should still be greater in septic systems because of the larger concentration of undigested wastes entering soil-absorption fields.

2. Detergent concentrations should decrease in both systems as bacterial digestion continues and filtration occurs. The decrease should be greatest in septic systems because of the change from anaerobic conditions in treatment tanks to aerobic conditions in soil-absorption fields. However, detergent concentrations should still be greater in septic systems because of the larger concentration of undigested detergents entering soil-absorption fields.

3. Dissolved-oxygen concentrations should increase in septic systems as the effluent absorbs oxygen from the air. Dissolved-oxygen concentrations should decrease in aeration systems because the effluent is not being mechanically aerated in soil-absorption fields. However, dissolved-oxygen concentrations should still be greater in aeration systems because of the lack of dissolved oxygen in the effluent entering soil-absorption fields from septic tanks and because biochemical oxygen demand is greater in septic systems.

4. Dissolved-nitrite concentrations should increase in septic systems because additional oxygen is available for bacterial digestion of wastes containing nitrogen compounds. Nitrite concentrations should decrease in aeration systems as bacterial digestion of wastes continues or is completed.

5. Dissolved-nitrate concentrations should increase in both systems as bacterial digestion of wastes continues. Nitrate concentrations should still be the same or greater in aeration systems depending on how much nitrate is formed in the septic system soil-absorption field; if wastewater residence times are short in the field, nitrate formation may be limited. Because nitrate does not readily combine with other constituents to form compounds that may precipitate or be filtered out of the effluent (Polkowski and Boyle, 1970; Elliot and McCalla, 1973), nitrate concentration, if not used by plants growing over the field, generally does not decrease as the effluent moves thorugh soil-absorption fields.

6. Dissolved-sulfate concentrations initially should increase in both systems. As bacterial digestion of wastes continues, small sulfur-containing molecules are released. Concentrations should then decrease as compounds either are incorporated in biological organisms or are filtered out of the effluent as it moves through soil-absorption fields. Dissolved-sulfate concentrations should still be equal or greater in aeration systems because of the larger concentrations entering soil-absorption fields, and the possibility of short wastewater residence times. 
7. Dissolved solids in both systems generally are increased by solubilization, oxidation, and hydrolysis, or by evaporation, although dissolved-solids concentrations may be decreased by filtration, consumption in biological metabolism, or by incorporation into biological organisms. Dissolved-solids concentrations should still be greater in aeration systems because of the larger concentrations entering soil-absorption fields.

Results of the comparisons for effluent from the soil-absorption fields are presented in table 5. The results, with the exception of the average concentration of dissolved oxygen in effluent from aeration systems, are consistent with the expected functioning of the soil-absorption fields. Insufficient data were available on dissolved-oxygen concentrations in effluent from aeration systems, so conclusions cannot be made with any certainty.

\section{SUMMARY}

The effects on ground-water quality of residential wastewater-treatment systems were determined in representative parts $\left(0.25-\mathrm{mi}^{2}\right.$ areas) of Evergreen Meadows, Marshdale, and Herzman Mesa. Ground-water quality is degraded to some extent in all the communities. Age of community; average lot size; slope of land surface; composition, permeability, and thickness of surficial material; density, size, and orientation of bedrock fractures; maintenance of wastewater-treatment systems; and presence of animals are factors possibly contributing to the degradation of ground-water quality.

Ground water in Evergreen Meadows, the youngest community (subdivided in 1969) and the community with the largest average lot size ( 3.5 acres), contains the smallest chemical and bacterial concentrations and is most suitable for use as a source of drinking water. Disinfection of the water to avoid bacterial contamination probably is not warranted at this time (1979). However, the potential for increases in chemical and bacterial concentrations in the ground water is indicated on the basis of the small average slope of the land surface and the composition, permeability, and thickness of surficial material.

On the basis of the chemical and bacterial quality of the ground water in Marshdale, the oldest community (subdivided in 1923) and the community with the smallest average lot size (1.2 acres), disinfection of the water to avoid bacterial contamination may be warranted, particularly in the area immediately northeast of State Highway 73. Bacterial contamination was the only major water-quality problem identified in Marshdale during the study.

On the basis of chemical and bacterial quality, the ground water in Herzman Mesa, the community of intermediate age (subdivided in 1946) and intermediate average lot size ( 1.9 acres), is the least suitable for use as drinking water, especially in the north-central and northwestern parts of the area. Because bacteria were found in the ground water in several parts of the area, disinfection of the water to avoid bacterial contamination may be warranted throughout the area. Concentrations of dissolved nitrite plus nitrate exceeded the Colorado mandatory drinking-water standard of $10 \mathrm{mg} / \mathrm{L}$ as nitrogen in water from three wells located in the north-central and northwestern parts of the area. 
Table 5.--Comparison between average concentrations of selected constituents in effluent from soil-absorption fields

\begin{tabular}{|c|c|c|c|}
\hline Const ituent & $\begin{array}{c}\text { Change in av } \\
\text { tion in effl } \\
\text { absorption fi } \\
\text { to average cc } \\
\text { treatment- } \\
\text { Septic-system } \\
\text { field }\end{array}$ & $\begin{array}{l}\text { rage concentra- } \\
\text { ent from soil- } \\
\text { lds with respect } \\
\text { ncentration in } \\
\text { ank effluent } \\
\text { Aeration-system } \\
\text { field } \\
\end{array}$ & $\begin{array}{c}\text { Comparison of increase or } \\
\text { decrease of average concen- } \\
\text { trations in effluent }\end{array}$ \\
\hline $\begin{array}{l}\text { Biochemical oxygen } \\
\text { demand- }\end{array}$ & Decrease & Decrease & $\begin{array}{l}\text { Decrease was about } 1.8 \text { times } \\
\text { greater in septic-system } \\
\text { effluent. Average concen- } \\
\text { tration greater in septic- } \\
\text { system effluent. }\end{array}$ \\
\hline Detergents- & Decrease & Decrease & $\begin{array}{l}\text { Decrease was about } 9.3 \text { times } \\
\text { greater in septic-system } \\
\text { effluent. Average concen- } \\
\text { tration greater in septic- } \\
\text { system effluent. }\end{array}$ \\
\hline Dissolved oxygen---- & Increase ${ }^{1}$ & $(2)$ & Insufficient data. \\
\hline Nitrite, dissolved-- & Increase 3 & Decrease ${ }^{4}$ & $\begin{array}{l}\text { Average concentration still } \\
\text { greater in aeration-system } \\
\text { effluent. }\end{array}$ \\
\hline Nitrate, dissolved-- & Increase & Increase & $\begin{array}{l}\text { Increase was about } 11 \text { times } \\
\text { greater in aeration-system } \\
\text { effluent. Average concen- } \\
\text { tration still greater in } \\
\text { aeration-system effluent. }\end{array}$ \\
\hline Sulfate, dissolved-- & Decrease & Decrease & $\begin{array}{l}\text { Decrease was about } 2.6 \text { times } \\
\text { greater in aeration-system } \\
\text { effluent. Average concen- } \\
\text { tration still greater in } \\
\text { aeration-system effluent. }\end{array}$ \\
\hline Dissolved solids---- & Increase & Increase & $\begin{array}{l}\text { Increase was about } 7.4 \text { times } \\
\text { greater in aeration-system } \\
\text { effluent. Average concen- } \\
\text { tration still greater in } \\
\text { aeration-system effluent. }\end{array}$ \\
\hline
\end{tabular}

${ }^{1}$ Average concentration increased about 2.0 times.

2 Insufficient data.

${ }^{3}$ Average concentration increased about 4.9 times.

${ }^{4}$ Average concentration decreased about 7.5 times. 
Concentrations of selected chemical constituents in effluent from treatment tanks and from soil-absorption fields were used to compare septic and aeration systems, the two principal types of residential wastewater-treatment systems in the study area. Results of the comparison for effluent from treatment tanks were consistent with expected results, based on the processes by which the two systems function. Anaerobic treatment of wastes in septic tanks is characterized by greater biochemical oxygen demand and greater concentrations of detergents resulting from incomplete biological digestion of wastes. Aerobic treatment of wastes in aeration tanks is characterized by greater concentrations of dissolved oxygen, nitrite, nitrate, and sulfate that are produced during the biological digestion of wastes.

Results of the comparisons for effluent from the soil-absorption fields were consistent with the expected functioning of the aerobic soil-absorption fields. Biochemical oxygen demand, concentrations of detergents, and sulfate decreased in both systems. Concentrations of dissolved oxygen and nitrite increased in septic systems and decreased in aeration systems. Concentrations of nitrate increased in both systems. Concentrations of dissolved solids remained about the same in septic systems and increased in aeration systems.

\section{SELECTED REFERENCES}

Allen, M. J., and Geldreich, E. E., 1975, Bacteriological criteria for groundwater quality: Ground Water, v. 75, p. 45-52.

Allen, M. J., and Morrison, S. M., 1973, Bacterial movement through fractured bedrock: Ground Water, v. 11 , no. 2, p. 6-10.

American Public Health Association, 1975, Standard methods for the examination of water and waste-water, (14th ed.): Washington, D.C., American Public Health As sociation, 1193 p.

Barshied, R. D., and El-Baroudi, H. M., 1974, Physical-chemical treatment of septic tank effluent: Water Pollution Control Federation Journal, v. 46, p. 2347-2354.

Behnke, Jerold, 1975, A summary of the biogeochemistry of nitrogen compounds in ground water: Journal of Hydrology, v. 27, p. 155-167.

Bennett, E. R., 1975, Panel discussion-What's happening in Colorado, in Ward, R. C., ed., Home Sewage Disposal in Colorado, Workshop, 2d, Fort Collins, 1975, Proceedings: Fort Collins, Colorado State University, Information Series 20 , p. 65-67.

Bennett, E. R., and Linstedt, K. D., 1975, Individual home wastewater characterization and treatment: Fort Collins, Colorado State University, Environmental Resources Center Completion Report Series 66, July 1975, 137 p.

Bennett, E. R., Lindstedt, K. D., and Felton, John, 1975, Comparison of septic tank and aerobic treatment units: The impact of wastewater variations on these systems, in Jewell, W. J., and Swan, Rita, eds., Rural Environmental Engineering Conference on Water Pollution Control in Low Density Areas, Proceedings, Warren, Vermont, 1973: Hanover, N. H., University Press of New England, p. 95-108. 
Bennett, E. R., Linstedt, K. D., and McBride, R. N., 1973, Individual home aerobic wastewater treatment systems, in 0'Brian, W. J., ed., Sanitary Engineering Conference, 23d, Lawrence, 1973, Transactions: Lawrence, University of Kansas, p. 71-96.

Bernhart, A. P., 1973, Treatment and disposal of waste water from homes by soil infiltration and evapotranspiration: Toronto, University of Toronto Press, $173 \mathrm{p}$.

Bongiorno, S., Gumbardo, R., Macina, G., Foley, S., Sabol, T., and Herlihy, J., 1976, Detection of nonpoint pollution of small streams in southwestern Connecticut: American Laboratory, v. 8, p. 9-19.

Brown, Eugene, Skougstad, M. W., and Fishman, M. J., 1970, Methods for collection and analysis of water samples for dissolved minerals and gases: U.S. Geological Survey Techniques of Water-Resources Investigations, Book 5, Chapter A4, $165 \mathrm{p}$.

Bryant, Bruce, 1974, Reconnaissance geologic map of the Conifer Quadrangle, Jefferson County, Colorado: U.S. Geological Survey Miscellaneous Field Studies Map MF-597, scale 1:24,000.

Campbel1, M. D., and Lehr, J. H., 1973, Rural water systems planning and engineering guide: Washington, D.C., Committee on rural water, $150 \mathrm{p}$.

Colorado Department of Health, 1967, Standards for the quality of water supplied to the public: Denver, Colorado State Board of Health, 8 p.

1977, Primary drinking water regulations for the State of Colorado: Denver, Water Quality Control Division, $60 \mathrm{p}$.

Elliott, L F., and McCalla, T. M., 1973, The fate of nitrogen from animal wastes, in Wiese, R. A., and Axthelm, D. D., compilers, Nitrogen in the Environment, Professional Conference, Lincoln, Nebr., 1973, Proceedings: Lincoln, Nebraska Continuing Education Center, p. 86-110.

Feth, J. H., 1967, Chemical characteristics of bulk precipitation in the Mojave Desert region, California: U.S. Geological Survey Professional Paper 575-C, p. 222-227.

Franks, A. L., 1972, Geology for individual sewage disposal systems: California Geology, v. 25, p. 195-203.

Geldreich, E. E., 1966, Sanitary significance of fecal coliforms in the environment: Washington, D.C., Government Printing Office, Water Pollution Control Research Series Publication No. WP-20-3, $110 \mathrm{p}$. 1972, Water-borne pathogens, in Mitchell, R., ed., Water pollution microbiology: New York, Wiley-Interscience, p. 207-241.

Goerlitz, D. F., and Brown, Eugene, 1972, Methods for analys is of organic substances in water: U.S. Geological Survey Techniques of Water-Resources Investigations, Book 5, Chapter A3, $40 \mathrm{p}$.

Goldberg, M. C., 1971, Sources of nitrogen in water, in Smith, E. H., and Willrich, T. W., eds., The role of agriculture in clean water: Ames, lowa State University Press, Chapter 7, p. 94-123.

Goldstein, S. N., and Moberg, W. J., Jr., 1973, Wastewater treatment systems for rural communities: Washington, D.C., Committee on Rural Water, 340 p.

Gordon, R. C., 1972, Winter survival of fecal indicator bacteria in a subarctic Alaskan river: U.S. Environmental Protection Agency, Environmental Protection Technology Series, EPA-R2-72-013, $41 \mathrm{p}$. 
Hall, D. C., 1975, Panel discussion--What's happening in Colorado, in Ward, R. C., ed., Home Sewage Disposal in Colorado Workshop, 2d, Fort Collins, 1975, Proceedings: Fort Collins, Colorado State University Information Series 20, P. 67-70.

Hall, D. C., Hillier, D. E., Cain, Doug, and Boyd, E. L., 1979, Water resources of Boulder County, Colorado: Colorado Geological Survey Bulletin 42, $97 \mathrm{p}$.

Hall, D. C., and Johnson, C. J., 1979, Drinking water quality and variations in water levels in the fractured crystalline-rock aciuifer, west-central Jefferson County, Colorado: U.S. Geological Survey Water-Resources Investigations 79-94, 52 p.; available from U.S. Department of Commerce, National Technical Information Service, Springfield, Va., as report PB-80-128 580.

Hall, M. H., 1970, Water quality degradation by septic tank drainage: Augusta, ME, $6 \mathrm{p}$.

Hammer, M. J., 1973, Control of nitrogen in wastewaters, in Wiese, R. A., and Axthelm, D. D., compilers, Nitrogen in the Environment Professional Conference, Lincoln, Nebr., 1973, Proceedings: Lincoln, Nebraska Continuing Education Center, p. 57-73.

Hofstra, W. E., and Hall, D. C., 1975a, Geologic control of supply and quality of water in the mountainous part of Jefferson County, Colorado: Colorado Geological Survey Bulletin 36, $51 \mathrm{p}$.

1975b, Hydrogeologic and water-quality data in western Jefferson County, Colorado: Colorado Water Conservation Board Water-Resources Basic-Data Release 36, $51 \mathrm{p}$.

International Standing Committee on Water Quality and Treatment, 1974, Nitrate in water supplies: Aqua, No. 1, p. 5-24.

Jefferson County Health Department, 1974 [revised 1977], Individual sewage disposal systems regulation: Lakewood, Colo., $26 \mathrm{p}$.

Klein, J. M., Goddard, K. E., and Livingston, R. K., 1978, Appraisal of the water resources of Park and Teller Counties, Colorado: Colorado Water Conservation Board Water-Resources Circular 36, 79 p.

Laak, Rein, Healy, K. A., and Hardisty, D. M., 1974, Rational basis for septic tank system design: Ground Water, v. 12, p. 348-355.

McKee, J. E., and Wolf, H. W., eds., 1971, Water quality criteria, 2d ed.: California Water Resources Control Board Publication 3-A, $548 \mathrm{p}$.

Mallman, W. L., 1972, The role of tile drainage in the design of septic tank drain fields, in Ward, R. C., ed., Home Sewage Disposal in Colorado Workshop, 1st, Fort Collins, 1972, Proceedings: Fort Collins, Colorado State University, Information Series 4, p. 34-37.

Miller, J. C., 1972, Nitrate contamination of the water-table aquifer in Delaware: Newark, Delaware Geological Survey, Report of Investigations 20.

Morrill, G. B., III, and Toler, L. G., 1973, Effect of septic-tank wastes on quality of water, Ipswitch and Shawsheen River basins, Massachusetts: U.S. Geological Survey Journal of Research, v. 1, p. 117-120.

Morrison, S. M., 1972, Notes and comments on microbiological aspects of home sewage disposal, in Ward, R. C., ed., Home Sewage Disposal in Colorado Workshop, 1st, Fort Collins, 1972, Proceedings: Fort Collins, Colorado State University, Information Series 4, p. 23-28.

National Academy of Sciences and National Academy of Engineering, 1973 [1974], Water quality criteria, 1972: Washington, D.C., U.S. Government Printing office, 594 p. 
0sweiler, Gary, 1973, Effects of nitrogen on animal health, in Wiese, R. A., and Axthelm, D. D., compilers, Nitrogen in the Environment Professional Conference, Lincoln, Nebr., 1973, Proceedings: Lincoln, Nebraska Continuing Education Center, p. 15-24.

Otis, R. J., and Boyle, W. C., 1976, Performance of single household treatment units: American Society of Civil Engineers Proceedings Paper 11895, Environmental Engineering Division Journal, v. 102, no. EEl, p. 175-189.

Patterson, J. W., Minear, R. A., and Nedued, T. K., 1971, Septic tanks and the environment: Illinois Institute of Environmental Quality; also available from the National Technical Information Service, PB-204 529, 98 p.

Polkowski, L. B., and Boyle, W. C., 1970, Ground water quality adjacent to septic tank-soil absorption system: Madison, Wisconsin Department of Natural Resources, $84 \mathrm{p}$.

Ramaley, R. F., 1973, Effect of nitrogen on human health--Nitrates, nitrites, and methemoglobinemia in infants, in Wiese, R. A., and Axthelm, D. D., compilers, Nitrogen in the Environment Professional Conference, Lincoln, Nebr., 1973, Proceedings: Lincoln, Nebraska Continuing Education Center, p. 3-11.

Robeck, G. G., Rendixen, T. W., Schwartz, W. A., and Woodward, R. L., 1964, Factors influencing the design and operation of soil systems for waste treatment: Water Pollution Control Federation Journal, v. 30, p. 971-983.

Romero, J. C., 1970, The movement of bacteria and viruses through porous media: Ground Water, v. 8, p. 37-48.

Saffigna, P. G., and Keeney, D. R., 1977, Nitrate and chloride in ground water under irrigated agriculture in central Wisconsin: Ground Water, v. 15, p. 170177.

Schmidt, P. W., 1976, Map showing relative amounts of soil and bedrock in the Conifer quadrangle and adjoining areas to the west, Colorado: U.S. Geological Survey Miscellaneous Field Studies Map MF-770.

Shearer, L. A., Goldsmith, J. R., Young, Clarence, Kearns, 0. A., and Tamplin, B. R., 1972, Methemoglobin levels in infants in an area with high nitrate water supply: American Public Health Journal, v. 62, p. 1174-1180.

Shirley, R. L., 1975, Nutritional and physiological effects of nitrates, nitrites, and nitrosamines: Bioscience, v. 25, p. 789-794.

Shuval, H. 1., and Gruener, Nachman, 1972, Epidemiological and toxilogical aspects of nitrates and nitrites in the environment: American Public Health Journal, v. 62 , p. 1045-1052.

Slack, K. V., Averett, R. C., Greeson, P. E., and Lipscomb, R. G., 1973, Methods for collection and analysis of aquatic biological and microbiological samples: U.S. Geological Survey Techniques of Water-Resources Investigations, Book 5, Chapter A4, 165 p.

Snow, D. T., 1968, Hydraulic characteristics of fractured metamorphic rocks of the Front Range and implications to the Rocky Mountain Arsenal well: Golden, Colorado School of Mines Quarterly, v. 63, no. 1, 32 p.

U.S. Environmental Data Service, 1972-74, Climatological data, Colorado: U.S. Environmental Data Service, v. 77, nos. 10-12; v. 78, nos. 1-12; v. 79, nos. 1-3.

U.S. Environmental Protection Agency, 1976a, Manual of water well construction practices: U.S. Environmental Protection Agency, Water Supply Division, EPAnos. $1-3$. 
U.S. Environmental Protection Agency, 1976b, National interim primary drinking water regulations: U.S. Environmental Protection Agency 570/9-76-003, 159 p. 1977, National secondary drinking water regulations: Federal Register, v. 42, no. 62, Thursday, March 31, 1977, Part I, p. 17143-17147.

U.S. Public Health Service, 1962, Drinking water standards: U.S. Public Health Service Publication 956,61 p.

1967, Manual of septic-tank practice: U.S. Department of Health, Education and Welfare Publication (HSM) 72-10020, $92 \mathrm{p}$.

U.S. Weather Bureau, 1967a, Normal annual precipitation, normal May-September precipitation, 1931-60, Colorado: Denver, Colorado Water Conservation Board map. 1967b, Normal annual precipitation, normal October-April precipitation, 19311960, Colorado: Denver, Colorado Water Conservation Board map.

Viraraghavan, R., and Warnock, R. G., 1976, Efficiency of a septic tile system: Water Pollution Control Federation Journal, v. 48, p. 934-944.

Walker, W. H., 1973, Ground-water nitrate pollution in rural areas: Ground Water, v. 11 , p. 19-22.

Waltz, J. P., 1972a, Geological factors of home sewage disposal, in Ward, R. C., ed., Home Sewage Disposal in Colorado, Workshop, 1st, Fort Collins, 1972, Proceedings: Fort Collins, Colorado State University, Information Series no. 4, p. 29-33.

$1972 b$, Methods of geologic evaluation of pollution potential at mountain homesites: Ground Water, v. 10, p. 42-49.

Wiese, R. A., 1973, Overview of natural sources of nitrogen, in Wiese, R. A., and Axthelm, D. D., compilers, Nitrogen in the Environment Professional Conference, Lincoln, Nebr., 1973, Proceedings: Lincoln, Nebraska Continuing Education Center, p. 190-195.

Wood, W. W., 1976, Guidelines for collection and field analysis of ground-water samples for selected unstable constituents: U.S. Geological Survey Techniques of Water-Resources Investigations, Book 1, Chapter D2, 24 p. 
SUPPLEMENTAL DATA 

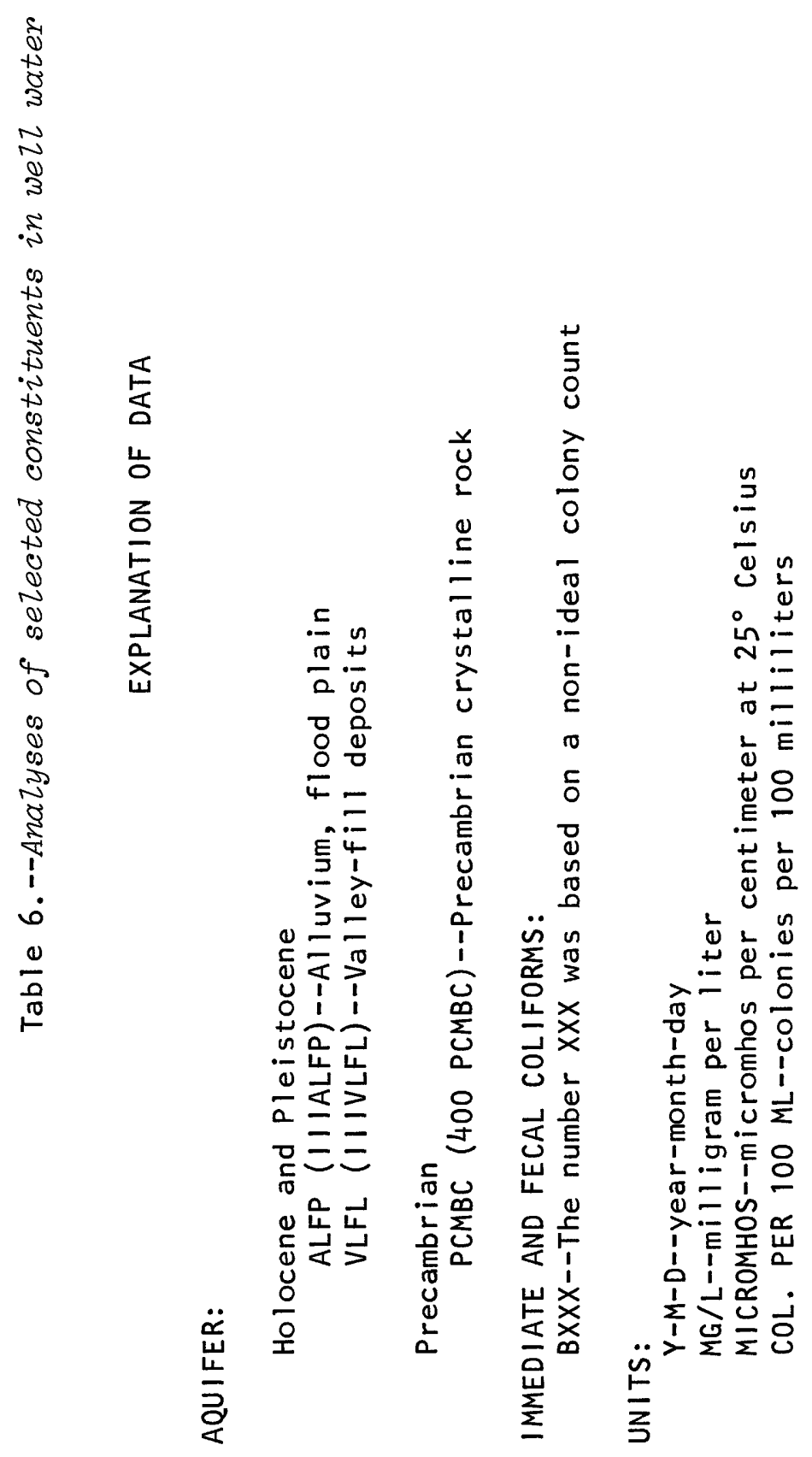


\begin{tabular}{|c|c|c|c|c|c|c|c|c|c|c|c|c|c|c|c|c|c|c|c|c|}
\hline 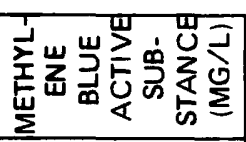 & $\begin{array}{l}8 \\
0\end{array}$ & 8 & 8 & 임 & 8 & ? & ㅇ. & 웅 & ㅇ. & 1 & 8 & 8 & 잉 & 웅 & 음 & 웅 & 1 & 웅 & 8 & 응 \\
\hline 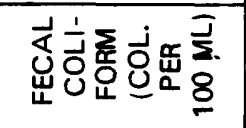 & v & $\bar{v}$ & $\bar{v}$ & $\bar{v}$ & $\bar{v}$ & $\bar{v}$ & $\bar{v}$ & $\bar{v}$ & $\bar{v}$ & $\bar{v}$ & $\bar{v}$ & $\bar{v}$ & $\bar{v}$ & $\bar{v}$ & $\bar{v}$ & $\begin{array}{l}\bar{v} \\
7\end{array}$ & 1 & $\bar{v}$ & $\bar{v}$ & $\bar{v}$ \\
\hline 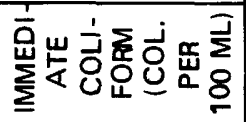 & $\bar{v}$ & $\bar{v}$ & $\bar{v}$ & $\bar{v}$ & $\bar{v}$ & $\frac{n}{\infty}$ & $\bar{v}$ & $\bar{v}$ & $\bar{v}$ & $\bar{v}$ & $\bar{v}$ & $\bar{v}$ & $\bar{v}$ & $\bar{v}$ & $\bar{v}$ & $\bar{v}$ & 1 & $\bar{v}$ & $\bar{v}$ & $\begin{array}{l}\frac{1}{v} \\
y\end{array}$ \\
\hline 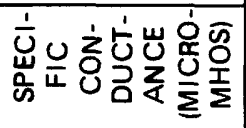 & 条 & 8 & $\stackrel{0}{N}$ & 尽 & $\begin{array}{l}8 \\
9 \\
m\end{array}$ & $\frac{1}{7}$ & 条 & 勇 & 象 & 素 & $\frac{9}{m}$ & $\stackrel{D}{N}$ & 站 & 文 & $\begin{array}{l}0 \\
n\end{array}$ & 욜 & $\begin{array}{l}0 \\
x \\
m\end{array}$ & $\begin{array}{l}D \\
h \\
N\end{array}$ & 욱 & $\begin{array}{l}n \\
N \\
n\end{array}$ \\
\hline 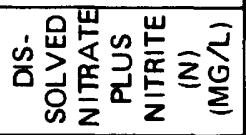 & $\vec{m}$ & $\bar{\Gamma}$ & $\underset{\sim}{N}$ & $\stackrel{*}{*}$ & $\stackrel{9}{n}$ & $\tilde{\theta}$ & $\vartheta$ & 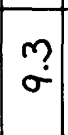 & $\stackrel{N}{*}$ & $\vartheta$ & $\bar{\sigma}$ & $\mathbb{N}$ & $\begin{array}{l}m \\
\dot{n}\end{array}$ & $\underline{n}$ & & $\stackrel{\infty}{\star}$ & 1 & $?$ & $\begin{array}{l}0 \\
\dot{b}\end{array}$ & $\infty$ \\
\hline 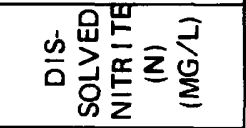 & $\begin{array}{l}N \\
0 \\
0\end{array}$ & $\overline{0}$ & $\overline{0}$ & $\begin{array}{l}n \\
0 \\
0\end{array}$ & No & $\begin{array}{l}\text { No } \\
0\end{array}$ & $\overline{0}$ & $\overline{0}$ & n. & 1 & $\overline{0}$ & $\overline{0}$ & $\overline{0}$. & \pm & $\overline{0}$ & ㅇ․ & 1 & $\overline{0}$ & $\overline{0}$ & $\overline{0}$ \\
\hline 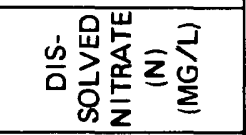 & $\begin{array}{l}\vec{m} \\
\dot{m}\end{array}$ & $\bar{\Gamma}$ & $\stackrel{N}{r}$ & $\stackrel{m}{-}$ & $\stackrel{9}{m}$ & ف & 2 & $\stackrel{\text { ma }}{\circ}$ & $\bar{a}$ & 1 & $\bar{\sigma}$ & 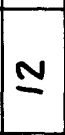 & $\stackrel{m}{n}$ & $\underline{n}$ & g & $\underset{\sim}{\infty}$ & 1 & $?$ & $\begin{array}{l}0 \\
\text { vi }\end{array}$ & $\infty$ \\
\hline 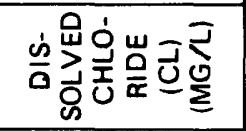 & \pm & O & $\underline{\infty}$ & 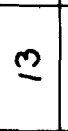 & $\simeq$ & N & m & $\stackrel{N}{N}$ & $\bar{N}$ & $\mp$ & $\overline{7}$ & $\vec{N}$ & $\stackrel{N}{N}$ & $\underset{\Psi}{\Psi}$ & $\bar{v}$ & $\stackrel{\infty}{\sim}$ & 1 & 䒺 & $\underset{f}{q}$ & $\bar{N}$ \\
\hline 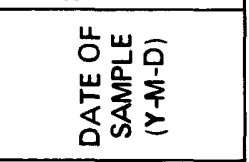 & $\begin{array}{l}a \\
\vdots \\
\dot{1} \\
\vdots \\
\vdots\end{array}$ & $\begin{array}{l}= \\
\dot{1} \\
0 \\
\dot{1} \\
2\end{array}$ & 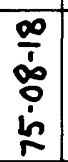 & $\begin{array}{l}\infty \\
\vdots \\
0 \\
0 \\
1 \\
1 \\
1\end{array}$ & $\begin{array}{l}\infty \\
\dot{0} \\
0 \\
\dot{1} \\
n\end{array}$ & 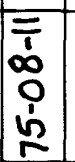 & $\begin{array}{l}\sigma \\
\frac{1}{5} \\
\dot{0} \\
\dot{n}\end{array}$ & \begin{tabular}{|c|} 
\\
$N$ \\
1 \\
0 \\
$i$ \\
\\
\end{tabular} & $\begin{array}{l}\text { W } \\
1 \\
0 \\
i \\
\vdots\end{array}$ & $\begin{array}{l}\frac{m}{1} \\
\dot{d} \\
\dot{1} \\
\frac{m}{r}\end{array}$ & 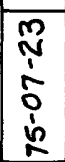 & $\begin{array}{l}\frac{\pi}{1} \\
\frac{1}{0} \\
\dot{n} \\
\frac{1}{2}\end{array}$ & 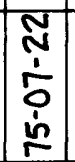 & $\begin{array}{l}\frac{1}{N} \\
\frac{1}{0} \\
\dot{2} \\
\end{array}$ & $\begin{array}{l}N \\
N \\
\dot{1} \\
0 \\
\dot{1} \\
\end{array}$ & $\begin{array}{c}\infty \\
0 \\
\dot{0} \\
\dot{i} \\
i \\
\end{array}$ & $\begin{array}{l}\tilde{r} \\
\dot{\delta} \\
\dot{0} \\
\dot{r} \\
\end{array}$ & $\begin{array}{l}\mathfrak{N} \\
\dot{i} \\
\dot{n} \\
\end{array}$ & \begin{tabular}{|c|}
7 \\
0 \\
1 \\
0 \\
0 \\
1 \\
1 \\
\end{tabular} & 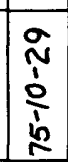 \\
\hline 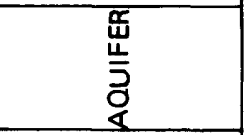 & $\sum_{\substack{\infty \\
\alpha}}^{0}$ & $\sum_{\substack{0 \\
0}}^{0}$ & $\sum_{0}^{0}$ & $\sum_{0}^{\infty}$ & $\sum_{0}^{\infty}$ & $\sum_{\substack{0 \\
0}}^{\infty}$ & $\sum_{0}^{0}$ & $\sum_{2}^{\infty}$ & $\sum_{\substack{0 \\
0}}^{0}$ & $\sum_{\substack{0 \\
0}}^{0}$ & & $\sum_{2}^{\infty}$ & $\sum_{\substack{0 \\
2}}^{\infty}$ & $\sum_{0}^{0}$ & $\sum_{0}^{\infty}$ & $\sum_{0}^{\infty}$ & & 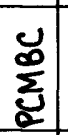 & $\sum_{\substack{\infty \\
0}}^{\infty}$ & $\sum_{0}^{0}$ \\
\hline 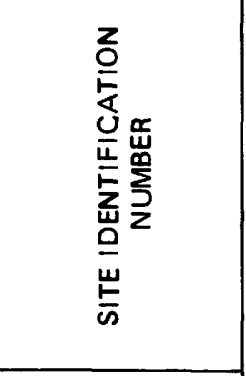 & 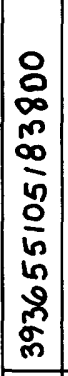 & $\begin{array}{l}0 \\
0 \\
m \\
\infty \\
\bar{n} \\
0 \\
\frac{9}{9} \\
n \\
9 \\
m \\
m\end{array}$ & $\begin{array}{l}0 \\
0 \\
N \\
m \\
\infty \\
\bar{n} \\
0 \\
\bar{n} \\
\bar{n} \\
\tilde{g} \\
\tilde{m}\end{array}$ & $\begin{array}{l}0 \\
m \\
m \\
m \\
0 \\
n \\
0 \\
\bar{n} \\
\bar{n} \\
\vdots \\
m \\
m \\
m\end{array}$ & $\begin{array}{c}0 \\
0 \\
a \\
N \\
\infty \\
\bar{n} \\
0 \\
\bar{n} \\
\tilde{n} \\
m \\
m \\
n \\
m\end{array}$ & 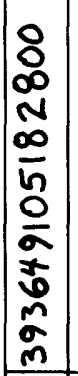 & 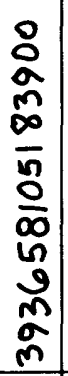 & $\begin{array}{c}0 \\
0 \\
\frac{0}{0} \\
\frac{0}{n} \\
0 \\
0 \\
6 \\
0 \\
m \\
0 \\
m\end{array}$ & 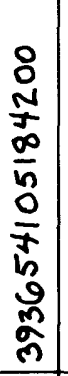 & 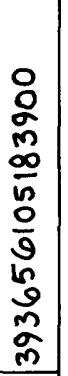 & & 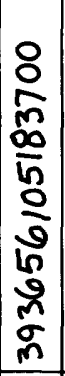 & $\mid \begin{array}{l}0 \\
0 \\
0 \\
0 \\
\infty \\
0 \\
0 \\
0 \\
0 \\
6 \\
9 \\
m \\
0 \\
m\end{array}$ & 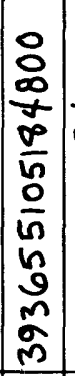 & 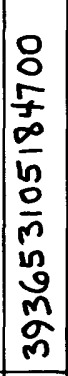 & 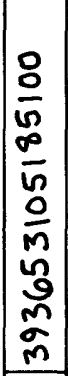 & & $\begin{array}{l}\frac{0}{\delta} \\
\frac{\sigma}{0} \\
\infty \\
\bar{n} \\
\frac{0}{\sigma} \\
\frac{\sigma}{5} \\
\frac{9}{9} \\
\frac{m}{m}\end{array}$ & 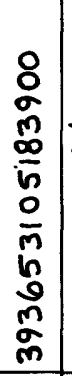 & 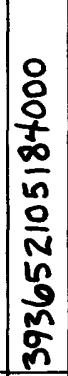 \\
\hline 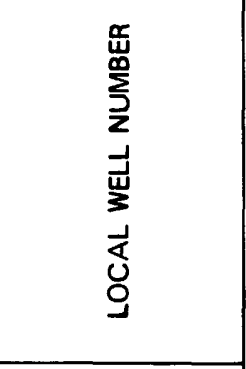 & 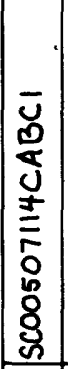 & $\begin{array}{l}N \\
u \\
0 \\
0 \\
\pm \\
\pm \\
5 \\
0 \\
6 \\
8 \\
u \\
\tilde{n}\end{array}$ & 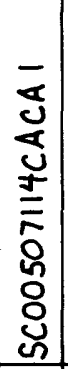 & 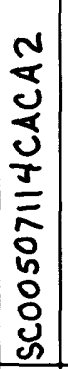 & 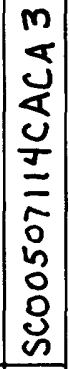 & 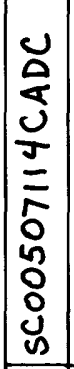 & 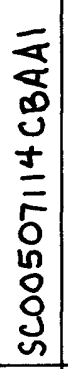 & 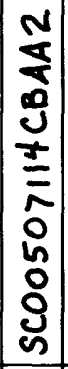 & 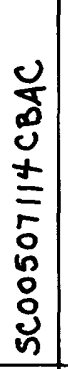 & $\begin{array}{l}0 \\
0 \\
0 \\
u \\
\pm \\
= \\
5 \\
0 \\
0 \\
0 \\
0\end{array}$ & & 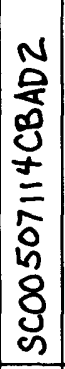 & \begin{tabular}{|c|}
0 \\
$\infty$ \\
0 \\
0 \\
0 \\
\pm \\
$\equiv$ \\
5 \\
0 \\
$n$ \\
0 \\
0 \\
0 \\
$n$ \\
\end{tabular} & 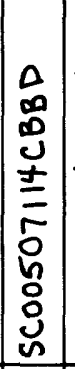 & 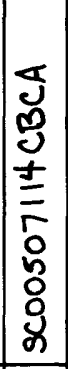 & 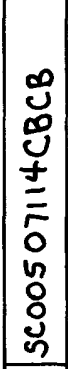 & & 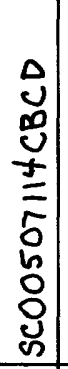 & $\begin{array}{l} \pm \\
0 \\
0 \\
0 \\
\pm \\
\bar{x} \\
0 \\
0 \\
0 \\
8 \\
y \\
y\end{array}$ & 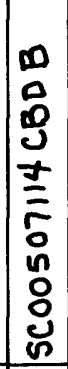 \\
\hline 屶方芯る号 & $\underline{m}$ & 흐 & 으 & 으 & 足 & $\stackrel{\circ}{\varrho}$ & \pm & $\frac{n}{=}$ & $\stackrel{\infty}{=}$ & $\cong$ & & 오 & $\begin{array}{l}\mathbf{N} \\
\simeq\end{array}$ & 吾 & $\stackrel{\stackrel{N}{ }}{\simeq}$ & $\stackrel{\infty}{=}$ & & $\stackrel{a}{\simeq}$ & 욜 & $\bar{m}$ \\
\hline
\end{tabular}




\begin{tabular}{|c|c|c|c|c|c|c|c|c|c|c|c|c|c|c|c|c|c|c|c|c|}
\hline 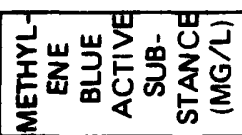 & 1 & $\begin{array}{l}0 \\
0 \\
0\end{array}$ & 웅 & 0 & ○! & 1 & $\begin{array}{c}m \\
0\end{array}$ & 8 & ㅇ. & 8 & 1 & 웅 & 요 & 응 & 1 & 음 & 8 & 1 & : & 웅 \\
\hline 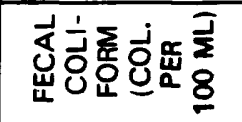 & 1 & $\bar{v}$ & $\bar{v}$ & $\bar{v}$ & $\bar{v}$ & $\bar{v}$ & $\bar{v}$ & $\bar{v}$ & $\bar{v}$ & $\bar{v}$ & $\bar{v}$ & $\bar{v}$ & $\bar{v}$ & $\bar{v}$ & $\bar{v}$ & $\bar{v}$ & $\bar{v}$ & $\bar{v}$ & $\bar{v}$ & $\bar{v}$ \\
\hline 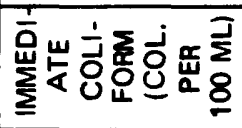 & 1 & $\bar{v}$ & $\bar{v}$ & $\bar{v}$ & $\bar{v}$ & $\bar{v}$ & $\bar{v}$ & $\infty$ & $\bar{v}$ & $\bar{v}$ & $\bar{v}$ & $\bar{v}$ & $\bar{v}$ & $\bar{v}$ & ท & $\bar{v}$ & $\bar{v}$ & $\bar{v}$ & $\begin{array}{l}N \\
D\end{array}$ & $\bar{v}$ \\
\hline 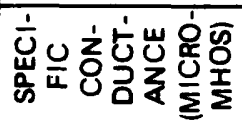 & $\begin{array}{l}8 \\
8\end{array}$ & $\stackrel{\circ}{\circ}$ & $\frac{\pi}{7}$ & $\left|\begin{array}{c}x \\
m \\
x\end{array}\right|$ & $\begin{array}{l}6 \\
\sigma \\
\mathbf{v}\end{array}$ & $\frac{a}{N}$ & $\begin{array}{l}n \\
x^{2}\end{array}$ & 움 & $\begin{array}{l}0 \\
m\end{array}$ & 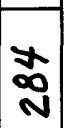 & $\begin{array}{l}0 \\
0 \\
0\end{array}$ & $\frac{x}{x}$ & $\begin{array}{l}0 \\
0 \\
\vdots\end{array}$ & $\frac{n}{m}$ & NN & $\begin{array}{c}0 \\
m \\
m\end{array}$ & 임 & $\bar{x}$ & $\mathfrak{N}$ & $\frac{n}{2}$ \\
\hline 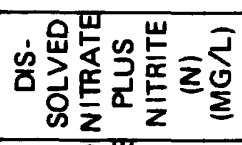 & 1 & 官 & N & $\tilde{v}$ & I. & $\underline{m}$ & $\begin{array}{l}\infty \\
0\end{array}$ & $\begin{array}{l}3 \\
\dot{n}\end{array}$ & $\stackrel{m}{-}$ & $\stackrel{n}{-}$ & $\begin{array}{l}0 \\
\dot{N}\end{array}$ & $\stackrel{N}{-}$ & $m$ & à & 0 & $\stackrel{N}{-}$ & $\bar{\sigma}_{.}$ & $\begin{array}{l}a \\
m\end{array}$ & $\frac{1}{3}$ & $\bar{N}$ \\
\hline 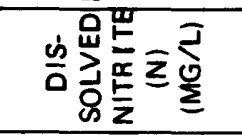 & 1 & $\begin{array}{l}0 \\
\vdots \\
0\end{array}$ & $\overline{0}$ & $\underline{n}$ & 웅 & 1 & $\stackrel{\varphi}{-}$ & 잉. & 웅 & 1 & 옹 & $\overline{0}$ & $\begin{array}{c}\mathbb{N} \\
0\end{array}$ & $\overline{0}$ & 1 & 웅 & ㅇ. & 1 & $\overline{0}$ & 웅 \\
\hline 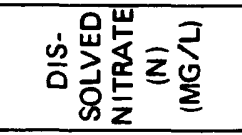 & 1 & بִ & $\stackrel{N}{v}$ & $\begin{array}{r}r \\
\dot{N}\end{array}$ & $\stackrel{\sigma}{N}$ & 1 & $\stackrel{N}{b}$ & $\stackrel{9}{\dot{m}}$ & $\stackrel{m}{\prime}$ & 1 & $\stackrel{0}{N}$ & $\stackrel{N}{-}$ & $m$ & $\begin{array}{l}\infty \\
*\end{array}$ & 1 & N & $\bar{\sigma}_{0}$ & 1 & m & $\overline{\mathbf{N}}$ \\
\hline 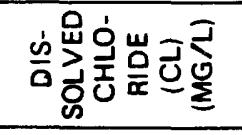 & 1 & $\bar{v}$ & 오 & $m$ & $\stackrel{n}{r}$ & $\bar{x}$ & $\tilde{N}$ & $\underline{n}$ & 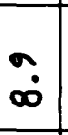 & 5 & $\begin{array}{l}7 \\
N\end{array}$ & $\stackrel{ }{N}$ & $\Sigma$ & $\begin{array}{l}0 \\
\dot{m}\end{array}$ & $\overline{\mathbf{N}}$ & 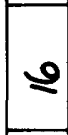 & $\begin{array}{c}N \\
\infty\end{array}$ & $\begin{array}{l}n \\
n\end{array}$ & $x$ & $\infty$ \\
\hline 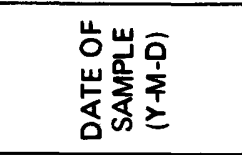 & $\begin{array}{l}0 \\
0 \\
1 \\
\vdots \\
0 \\
\vdots \\
1\end{array}$ & $\begin{array}{c}\infty \\
N \\
1 \\
0 \\
1 \\
1 \\
r\end{array}$ & $\begin{array}{l}\frac{1}{N} \\
\frac{1}{0} \\
0 \\
i\end{array}$ & $\begin{array}{l}\overline{0} \\
\dot{d} \\
\overline{1} \\
\end{array}$ & $\begin{array}{l}\overline{0} \\
\dot{N} \\
\frac{1}{n} \\
\end{array}$ & 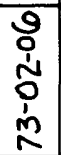 & 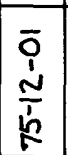 & $\begin{array}{l}m \\
1 \\
1 \\
0 \\
1 \\
1 \\
n\end{array}$ & $\begin{array}{l}N \\
\dot{0} \\
0 \\
\dot{b} \\
n\end{array}$ & $\begin{array}{l}0 \\
\dot{\sim} \\
0 \\
\dot{n} \\
i\end{array}$ & $\begin{array}{l}m \\
\frac{m}{1} \\
0 \\
0 \\
1 \\
n\end{array}$ & 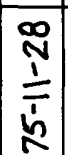 & $\begin{array}{l}\stackrel{\infty}{N} \\
\frac{1}{\dot{n}} \\
\end{array}$ & $\begin{array}{c}\infty \\
N \\
\frac{1}{1} \\
N\end{array}$ & $\begin{array}{l}\dot{0} \\
\dot{1} \\
0 \\
\dot{n} \\
\dot{m}\end{array}$ & $\begin{array}{l}\frac{7}{1} \\
0 \\
0 \\
\dot{1} \\
\end{array}$ & 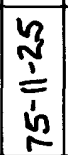 & $\begin{array}{l}\frac{m}{\dot{n}} \\
\dot{\tilde{n}} \\
\dot{m}\end{array}$ & $\frac{ \pm}{\frac{1}{b}}$ & 吕 \\
\hline 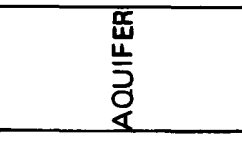 & & $\sum_{\substack{0 \\
\alpha}}^{0}$ & $\sum_{\substack{0 \\
0}}^{0}$ & $\sum_{8}^{8}$ & 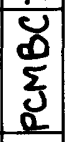 & 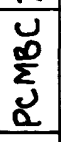 & 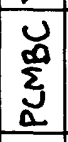 & 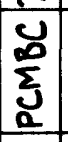 & 感 & $\sum_{\substack{0 \\
0}}^{1}$ & & $\begin{array}{l}0 \\
\sum \\
\Sigma \\
2\end{array}$ & $\begin{array}{l}0 \\
0 \\
\Sigma \\
\\
\end{array}$ & $\sum_{\substack{0 \\
0}}^{\infty}$ & 高 & 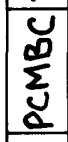 & 造 & $\begin{array}{l}0 \\
\infty \\
\vdots \\
0 \\
0\end{array}$ & & 号 \\
\hline 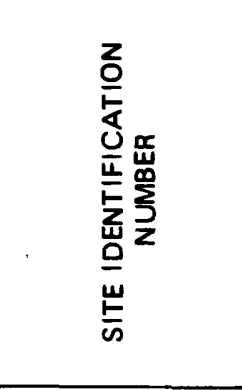 & & 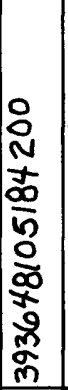 & 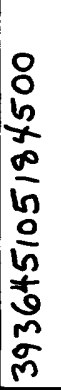 & $\begin{array}{l}0 \\
0 \\
n \\
m \\
\infty \\
\bar{n} \\
0 \\
\frac{0}{m} \\
\frac{1}{0} \\
m \\
\tilde{m} \\
\tilde{m}\end{array}$ & $\begin{array}{l}0 \\
0 \\
\bar{m} \\
\infty \\
\frac{\infty}{n} \\
0 \\
\infty \\
n \\
0 \\
m \\
\sigma \\
m\end{array}$ & 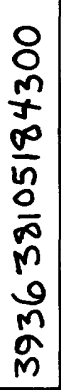 & $\begin{array}{c}0 \\
0 \\
0 \\
m \\
0 \\
n \\
0 \\
0 \\
m \\
m \\
m \\
\sigma \\
m\end{array}$ & $\mid \begin{array}{c}0 \\
8 \\
N \\
\infty \\
\frac{1}{6} \\
0 \\
n \\
7 \\
0 \\
m \\
5 \\
m\end{array}$ & 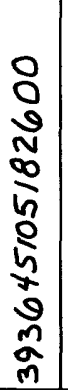 & 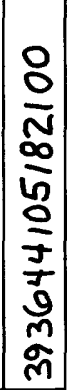 & & 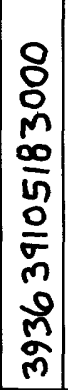 & $\begin{array}{c}0 \\
o \\
m \\
m \\
\infty \\
\bar{n} \\
0 \\
m \\
m \\
2 \\
\tilde{m} \\
m\end{array}$ & $\mid \begin{array}{c}0 \\
0 \\
N \\
m \\
\infty \\
n \\
n \\
0 \\
n \\
m \\
3 \\
m \\
o \\
m\end{array}$ & 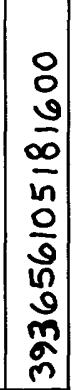 & $\begin{array}{l}0 \\
0 \\
0 \\
0 \\
0 \\
n \\
n \\
0 \\
0 \\
1 n \\
0 \\
m \\
\sigma \\
m\end{array}$ & $\mid \begin{array}{c}0 \\
0 \\
\infty \\
x \\
\infty \\
5 \\
0 \\
0 \\
5 \\
7 \\
n \\
m \\
0 \\
0\end{array}$ & $\begin{array}{c}0 \\
0 \\
\infty \\
m \\
\infty \\
n \\
b \\
0 \\
\frac{j}{j} \\
j \\
n \\
\tilde{\sigma} \\
m\end{array}$ & & 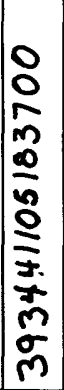 \\
\hline 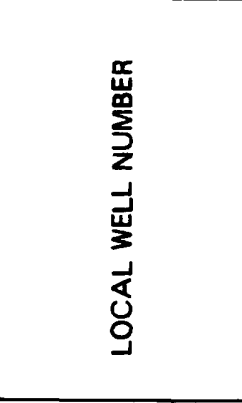 & & 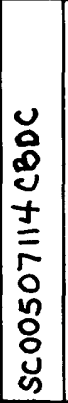 & 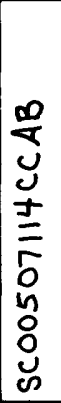 & 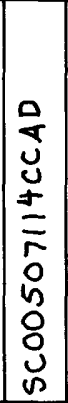 & 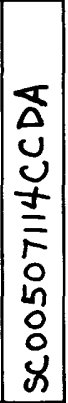 & 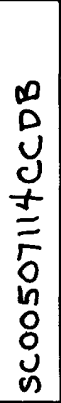 & $\begin{array}{l}0 \\
0 \\
u \\
u \\
\pm \\
\bar{N} \\
0 \\
0 \\
0 \\
g \\
0\end{array}$ & 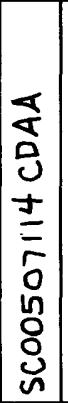 & 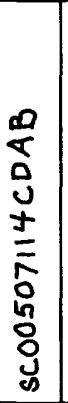 & 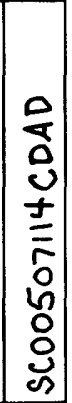 & & 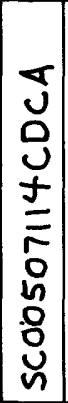 & 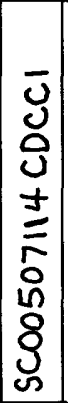 & 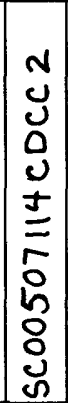 & 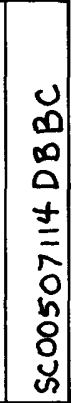 & $\begin{array}{l}y \\
0 \\
\infty \\
0 \\
1 \\
\pm \\
\bar{N} \\
0 \\
0 \\
0 \\
0 \\
0 \\
0 \\
n\end{array}$ & $\begin{array}{c}u \\
y \\
y \\
y \\
m \\
N \\
\tilde{5} \\
0 \\
n \\
8 \\
\mathcal{y}\end{array}$ & $\begin{array}{c}\bar{D} \\
D \\
u \\
u \\
m \\
N \\
T \\
O \\
0 \\
O \\
0 \\
0 \\
w\end{array}$ & & 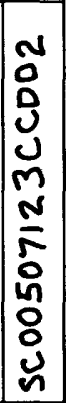 \\
\hline 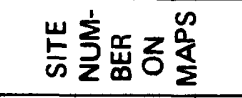 & & $\underline{m}$ & $\underline{m}$ & $\stackrel{m}{2}$ & $\underline{m}$ & 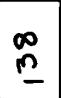 & $\stackrel{m}{m}$ & 오 & 王 & $\stackrel{m}{ \pm}$ & & $\underline{\underline{1}}$ & I & 은 & 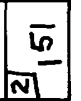 & $\frac{N}{n}$ & $\overline{0}$ & $\begin{array}{l}N \\
0 \\
N\end{array}$ & & m \\
\hline
\end{tabular}




\begin{tabular}{|c|c|c|c|c|c|c|c|c|c|c|c|c|c|c|c|c|c|c|c|c|}
\hline 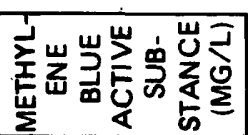 & $\begin{array}{l}0 \\
0 \\
0\end{array}$ & $\begin{array}{l}0 \\
0 \\
0\end{array}$ & 1 & ○ & ㅇ & : & 8 & ?. & : & 8 & 8 & จุ & ㅇ․ & : & 웅 & 우 & 오. & 8 & 8 & 웅 \\
\hline 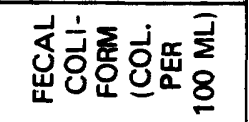 & $\bar{v}$ & $\bar{v}$ & $\bar{v}$ & $\bar{v}$ & $\bar{v}$ & v & $\bar{v}$ & $\bar{v}$ & $\bar{v}$ & $\bar{v}$ & $\bar{v}$ & - & $\bar{v}$ & $\bar{v}$ & $\bar{v}$ & $\bar{v}$ & $\bar{v}$ & $\bar{v}$ & $\bar{v}$ & $\bar{v}$ \\
\hline 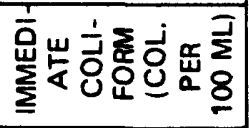 & $\bar{v}$ & $\bar{v}$ & $\bar{v}$ & $\bar{v}$ & $\bar{v}$ & $\bar{v}$ & $\bar{v}$ & $\bar{v}$ & $\bar{v}$ & $\bar{v}$ & $\bar{v}$ & N & $\bar{v}$ & $\bar{v}$ & $n$ & $\bar{v}$ & $\bar{v}$ & $\bar{v}$ & $\bar{v}$ & $\bar{v}$ \\
\hline 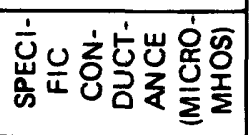 & 足 & 옷 & $\stackrel{a}{\infty}$ & 운 & $\begin{array}{l}0 \\
\text { N }\end{array}$ & 2 & $\begin{array}{l}\text { O } \\
\text { N }\end{array}$ & $\stackrel{n}{n}$ & O & $\begin{array}{l}n \\
n \\
n\end{array}$ & 品 & 8 & $\begin{array}{l}8 \\
\text { N }\end{array}$ & $\stackrel{n}{N}$ & $\begin{array}{l}n \\
N \\
N\end{array}$ & $\frac{n}{N}$ & $\stackrel{\circ}{N}$ & 은 & $\stackrel{0}{m}$ & $\stackrel{2}{N}$ \\
\hline 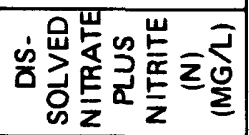 & 里 & $\stackrel{N}{N}$ & 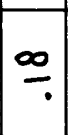 & $\bar{N}$ & $\bar{n}$ & $\simeq$ & $\hat{m}$ & $\stackrel{n}{m}$ & ले. & เ & $\stackrel{n}{-}$ & $?$ & $\begin{array}{l}n \\
m \\
m\end{array}$ & 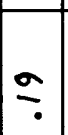 & \pm & $\overline{9}$ & ? & $\stackrel{m}{m}$ & 운. & $\stackrel{n}{n}$ \\
\hline 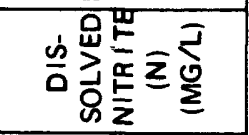 & $\begin{array}{l}1 \\
0 \\
0\end{array}$ & $\begin{array}{l}0 \\
0\end{array}$ & 1 & : & $\overline{0}$ & $\bar{D}$ & $\begin{array}{l}0 \\
0\end{array}$ & $\overline{0}$ & $\overline{0}$ & $\overline{0}$ & ㅇ. & $\stackrel{\infty}{0}$ & 8 & : & $\overline{0}$ & ○ & 8 & $\overline{0}$ & $\overline{0}$ & ○ \\
\hline 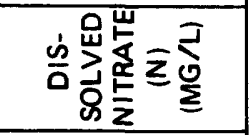 & $\begin{array}{l}\infty \\
m \\
0 \\
0\end{array}$ & $\stackrel{\sim}{N}$ & I & $\overline{\mathbf{N}}$ & in & $\stackrel{9}{ }$ & $m$ & m. & $m$ & nn & $\stackrel{n}{-}$ & $\exists$ & m & $\underline{\sigma}$ & $\stackrel{n}{-}$ & $\overline{9}$ & ?ָ. & ñ. & m. & $\stackrel{n}{q}$ \\
\hline 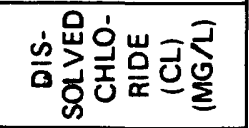 & $\dddot{\imath}$ & in & $\overline{\mathbf{N}}$ & $\stackrel{9}{=}$ & $?$ & $=$ & $\dot{x}$ & $\begin{array}{l}n \\
\dot{N}\end{array}$ & $\begin{array}{l}0 \\
\dot{m}\end{array}$ & $\frac{n}{n}$ & $\stackrel{m}{\sigma}$ & $=$ & 寈 & $\stackrel{\circ}{-}$ & $\infty$ & 1 & $\stackrel{n}{n}$ & $\stackrel{m}{\dot{v}}$ & $\stackrel{t}{-}$ & m \\
\hline 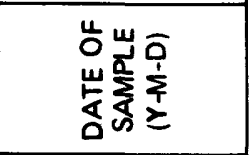 & 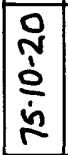 & $\begin{array}{c}\frac{\pi}{1} \\
\frac{1}{T} \\
\frac{1}{2}\end{array}$ & 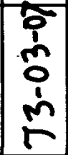 & $\begin{array}{c}n \\
\stackrel{n}{1} \\
\frac{1}{n} \\
n\end{array}$ & $\begin{array}{l}0 \\
0 \\
1 \\
0 \\
0 \\
1 \\
1\end{array}$ & $\frac{5}{1}$ & $\begin{array}{l}\frac{m}{\dot{m}} \\
\dot{0} \\
\dot{n} \\
r\end{array}$ & $\begin{array}{l}0 \\
0 \\
\dot{0} \\
0 \\
\dot{n} \\
\end{array}$ & $\begin{array}{l}m \\
\dot{\alpha} \\
0 \\
\dot{0} \\
\dot{1}\end{array}$ & 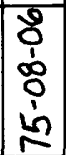 & $\begin{array}{l}n \\
0 \\
0 \\
0 \\
\text { in } \\
n\end{array}$ & $\begin{array}{l}0 \\
0 \\
0 \\
0 \\
i \\
1 \\
1\end{array}$ & $\begin{array}{l}n \\
0 \\
0 \\
0 \\
0 \\
1 \\
n\end{array}$ & $\frac{n}{\frac{1}{T}}$ & 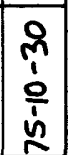 & 高 & \begin{tabular}{|l|}
$\frac{1}{1}$ \\
$\dot{1}$ \\
0 \\
0 \\
1 \\
\end{tabular} & $\begin{array}{l}\bar{y} \\
\dot{\infty} \\
0 \\
\dot{n} \\
1\end{array}$ & $\frac{1}{2}$ & $\frac{8}{\grave{c}}$ \\
\hline 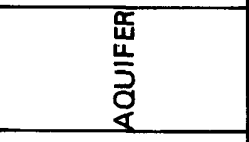 & $\begin{array}{l}0 \\
\infty \\
\sum \\
0 \\
0\end{array}$ & $\sum_{\substack{0 \\
\Sigma}}^{0}$ & $\sum_{\substack{0 \\
0}}^{\infty}$ & & $\sum_{0}^{\infty}$ & $\sum_{0}^{0}$ & $\sum_{0}^{\infty}$ & $\sum_{\substack{\infty \\
2}}^{\infty}$ & 感 & 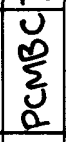 & 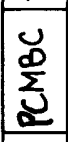 & \begin{tabular}{|c|} 
\\
\\
0 \\
0
\end{tabular} & 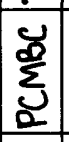 & $\sum_{\substack{0 \\
0}}^{0}$ & $\sum_{2}^{\infty}$ & $\sum_{\substack{0 \\
0}}^{0}$ & & $\sum_{0}^{\infty}$ & $\sum_{\substack{0 \\
0}}^{\infty}$ & $\sum_{n}^{\infty}$ \\
\hline 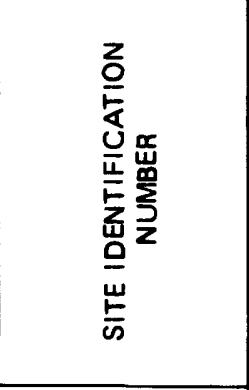 & $\mid \begin{array}{c}0 \\
0 \\
m \\
m \\
\infty \\
\infty \\
w \\
0 \\
0 \\
n \\
n \\
w \\
m \\
m \\
m \\
m\end{array}$ & $\begin{array}{l}0 \\
0 \\
n \\
n \\
\infty \\
0 \\
w \\
0 \\
\frac{1}{n} \\
7 \\
n \\
m \\
m \\
m\end{array}$ & $\mid \begin{array}{c}0 \\
0 \\
N \\
0 \\
n \\
0 \\
\frac{1}{7} \\
n \\
m \\
2 \\
m\end{array}$ & & $\begin{array}{l}8 \\
\frac{8}{N} \\
\infty \\
\frac{n}{n} \\
0 \\
\frac{0}{0} \\
+ \\
n \\
\tilde{m} \\
\sigma \\
m\end{array}$ & $\begin{array}{l}\frac{0}{g} \\
\frac{2}{\infty} \\
\frac{n}{n} \\
\frac{0}{n} \\
m \\
n \\
m \\
m \\
m\end{array}$ & 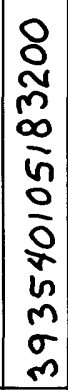 & $\begin{array}{c}0 \\
0 \\
n \\
m \\
\infty \\
0 \\
n \\
0 \\
\frac{n}{n} \\
m \\
n \\
m \\
\sigma \\
m\end{array}$ & $\begin{array}{c}0 \\
0 \\
9 \\
m \\
o \\
n \\
0 \\
0 \\
v \\
m \\
n \\
m \\
\sigma \\
m\end{array}$ & $\begin{array}{l}0 \\
\frac{0}{m} \\
\infty \\
\frac{n}{n} \\
0 \\
\frac{n}{n} \\
n \\
m \\
\sigma \\
m\end{array}$ & $\begin{array}{l}0 \\
0 \\
m \\
00 \\
\bar{n} \\
0 \\
n \\
m \\
n \\
m \\
\tilde{m} \\
m\end{array}$ & $\begin{array}{c}0 \\
0 \\
n \\
m \\
\infty \\
n \\
o \\
\frac{0}{N} \\
m \\
n \\
n \\
\tilde{n} \\
n\end{array}$ & $\begin{array}{c}0 \\
0 \\
n \\
m \\
\infty \\
\tilde{n} \\
0 \\
\frac{1}{n} \\
m \\
n \\
n \\
\sigma \\
m\end{array}$ & $\begin{array}{c}0 \\
0 \\
N \\
N \\
\infty \\
m \\
n \\
o \\
m \\
m \\
n \\
m \\
m \\
m\end{array}$ & $\begin{array}{c}0 \\
0 \\
n \\
n \\
\infty \\
n \\
n \\
0 \\
\frac{n}{n} \\
m \\
n \\
m \\
n \\
m\end{array}$ & 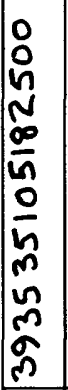 & & $\begin{array}{l}0 \\
0 \\
9 \\
N \\
0 \\
\frac{0}{n} \\
\frac{0}{N} \\
m \\
n \\
\tilde{n} \\
\tilde{m}\end{array}$ & $\begin{array}{l}0 \\
0 \\
\sigma \\
\infty \\
\bar{w} \\
\frac{0}{N} \\
m \\
m \\
m \\
m \\
m\end{array}$ & 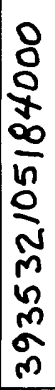 \\
\hline 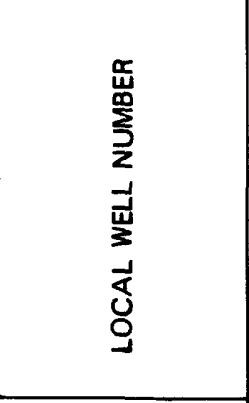 & $\begin{array}{l}\overline{0} \\
0 \\
0 \\
u \\
m \\
N \\
\tilde{n} \\
0 \\
n \\
0 \\
0 \\
\tilde{n} \\
\end{array}$ & $\begin{array}{l}n \\
\infty \\
u \\
0 \\
n \\
n \\
N \\
\Gamma \\
0 \\
n \\
0 \\
0 \\
u \\
\end{array}$ & 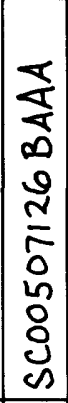 & & 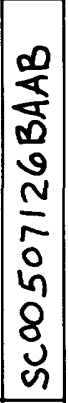 & $\begin{array}{l}0 \\
\frac{0}{8} \\
0 \\
0 \\
N \\
\frac{N}{N} \\
0 \\
0 \\
0 \\
0 \\
u \\
U\end{array}$ & $\begin{array}{l}n \\
0 \\
0 \\
0 \\
0 \\
N \\
\frac{0}{5} \\
0 \\
0 \\
8 \\
0 \\
n\end{array}$ & 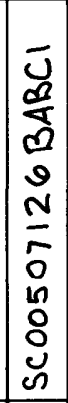 & 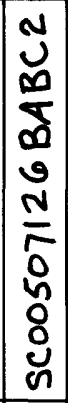 & $\mid \begin{array}{c}0 \\
0 \\
0 \\
0 \\
0 \\
N \\
N \\
0 \\
0 \\
0 \\
0 \\
0 \\
n\end{array}$ & 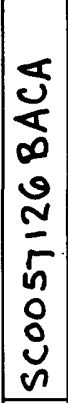 & 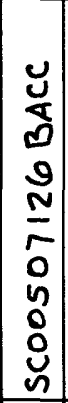 & 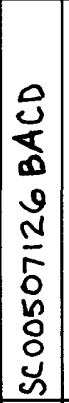 & 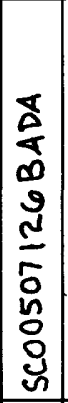 & 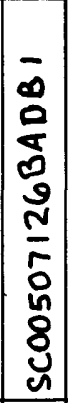 & 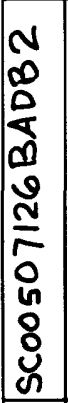 & & 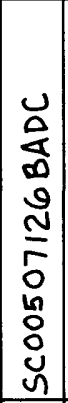 & 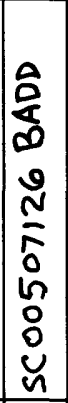 & 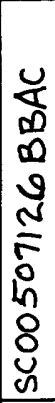 \\
\hline 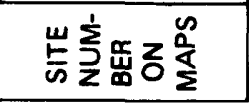 & $\begin{array}{l}J \\
0 \\
N\end{array}$ & $\begin{array}{l}n \\
0 \\
N\end{array}$ & $\begin{array}{l}0 \\
\text { D } \\
\end{array}$ & & 오 & $\overline{\bar{N}}$ & $\frac{m}{N}$ & $\frac{J}{N}$ & $\frac{n}{N}$ & $\frac{\infty}{w}$ & N & $\begin{array}{l}n \\
N \\
N\end{array}$ & $\widehat{N}$ & 药 & $\stackrel{n}{\sim}$ & M & & $\hat{n}$ & 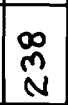 & 交 \\
\hline
\end{tabular}




\begin{tabular}{|c|c|c|c|c|c|c|c|c|c|c|c|c|c|c|c|c|c|c|c|c|}
\hline 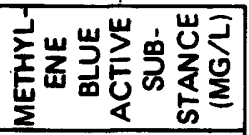 & $\begin{array}{l}0 \\
0 \\
0\end{array}$ & 이 & 8 & 8 & 1 & 8 & 웅 & 웅 & : & 우 & 1 & 이 & 웅 & 8 & 1 & 8 & $\begin{array}{l}0 \\
0\end{array}$ & 1 & 웅 & : \\
\hline 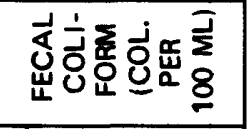 & $\bar{v}$ & $\begin{array}{l}\bar{v} \\
-\bar{T}\end{array}$ & $\bar{v}$ & $\bar{v}$ & $\bar{v}$ & $\bar{v}$ & $\bar{v}$ & $\bar{v}$ & $\bar{v}$ & $\bar{v}$ & $\bar{v}$ & $\bar{v}$ & v & $\bar{v}$ & 1 & $\bar{v}$ & $\bar{v}$ & $\bar{v}$ & $\bar{v}$ & $\bar{v}$ \\
\hline 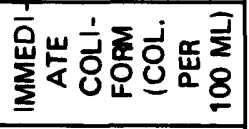 & $\bar{v}$ & $\begin{array}{l}-\bar{v} \\
-7\end{array}$ & $\bar{v}$ & $\bar{v}$ & $\bar{v}$ & $\bar{\gamma}$ & $\bar{v}$ & $\bar{v}$ & $\vec{v}$ & $\bar{v}$ & $\bar{v}$ & $\bar{v}$ & $\bar{v}$ & $\overline{7}$ & 1 & $\bar{v}$ & $\bar{v}$ & $\bar{v}$ & $\bar{v}$ & $\bar{v}$ \\
\hline 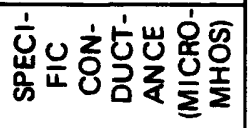 & $\begin{array}{l}0 \\
\text { N }\end{array}$ & $\stackrel{n}{7}$ & 욤 & $\begin{array}{l}n \\
\text { N }\end{array}$ & $\begin{array}{l}N \\
N \\
N\end{array}$ & $\frac{n}{n}$ & $\begin{array}{l}0 \\
6 \\
N\end{array}$ & $\begin{array}{l}0 \\
n \\
\text { N }\end{array}$ & $\begin{array}{l}\text { un } \\
\text { N }\end{array}$ & $\begin{array}{l}n \\
\infty \\
N\end{array}$ & $\stackrel{m}{N}$ & $\stackrel{\circ}{N}$ & 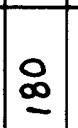 & O̊ & $\stackrel{\infty}{\infty}$ & $\begin{array}{l}0 \\
\infty \\
N\end{array}$ & 온 & 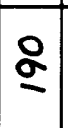 & @ & in \\
\hline 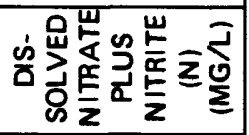 & $\dot{N}$ & $\stackrel{0}{\sim}$ & $\infty$ & $\begin{array}{l}\infty \\
\dot{N}\end{array}$ & $\vec{N}$ & $\vec{n}$ & 웅. & $\begin{array}{l}0 \\
\infty\end{array}$ & $\stackrel{n}{-}$ & $\begin{array}{l}\infty \\
\dot{m}\end{array}$ & 常 & 궁 & के & $\%$ & 1 & $\overline{0}$ & $\infty$ & $\stackrel{\infty}{N}$ & $\stackrel{m}{*}$ & 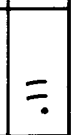 \\
\hline 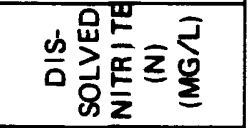 & $\begin{array}{l}8 \\
0 \\
0\end{array}$ & $\overline{0}$ & 8 & $\overline{0}$ & 1 & $\overline{0}$ & 8 & $\overline{0}$ & 임 & $\overline{0}$ & 1 & $\overline{0}$ & 웅 & 오. & 1 & 8 & $\bar{\delta}$ & 1 & 8 & $\overline{0}$ \\
\hline 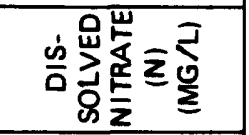 & $\begin{array}{l}\infty \\
v\end{array}$ & $\stackrel{0}{\circ}$ & $\begin{array}{l}\infty \\
\dot{v}\end{array}$ & $\begin{array}{l}\infty \\
\dot{N}\end{array}$ & 1 & $\vec{N}$ & 웅 & $\begin{array}{l}\infty \\
\infty\end{array}$ & $\stackrel{n}{-}$ & $\begin{array}{l}\infty \\
\dot{\rho}\end{array}$ & 1 & mo & 志 & $\begin{array}{l}\infty \\
0\end{array}$ & 1 & $\overline{0}$ & $\hat{0}$ & 1 & $\stackrel{m}{*}$ & $\underline{0}$ \\
\hline 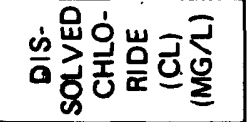 & $\stackrel{\overbrace{}}{N}$ & 을 & $\underline{m}$ & $n$ & $\stackrel{\mathrm{N}}{\mathrm{N}}$ & $\bar{N}$ & 7 & $\begin{array}{l}\pi \\
\mathbf{N}\end{array}$ & $\begin{array}{l}0 \\
\dot{0}\end{array}$ & $\begin{array}{l}\infty \\
\infty\end{array}$ & $\bar{\infty}$ & $\stackrel{\sim}{\sim}$ & $\begin{array}{l}\vec{m} \\
\dot{m}\end{array}$ & $\begin{array}{l}m \\
\dot{N}\end{array}$ & 1 & $\stackrel{9}{-}$ & $\stackrel{\infty}{-}$ & $\bar{N}$ & $r$ & $\because$ \\
\hline 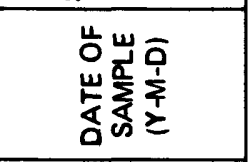 & $\begin{array}{l}3 \\
0 \\
1 \\
8 \\
\dot{1} \\
1 \\
\end{array}$ & $\frac{\overline{1}}{\grave{1}}$ & $\begin{array}{l}0 \\
0 \\
0 \\
0 \\
\text { ñ }\end{array}$ & $\begin{array}{c}\hat{0} \\
\dot{\alpha} \\
\\
\end{array}$ & $\begin{array}{c}\hat{o} \\
\dot{n} \\
\dot{p} \\
m \\
r\end{array}$ & $\begin{array}{l}\vec{T} \\
\stackrel{1}{\vdots} \\
\dot{i} \\
\end{array}$ & 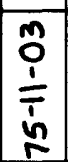 & \begin{tabular}{|l|} 
\\
0 \\
0 \\
0 \\
0 \\
$\dot{1}$ \\
$\dot{1}$ \\
\end{tabular} & $\begin{array}{l}0 \\
0 \\
1 \\
0 \\
0 \\
\dot{1} \\
1\end{array}$ & $\begin{array}{l}5 \\
\dot{2} \\
\frac{\dot{H}}{2}\end{array}$ & $\begin{array}{l}\sigma \\
\dot{m} \\
0 \\
\dot{m} \\
\sim\end{array}$ & $\begin{array}{l}\sigma \\
N \\
\dot{1} \\
0 \\
\dot{1} \\
N\end{array}$ & $\begin{array}{l}\text { J } \\
\dot{8} \\
8 \\
\dot{1}\end{array}$ & $\begin{array}{l}\text { Na } \\
\vdots \\
\vdots \\
\\
\end{array}$ & 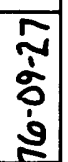 & $\begin{array}{l}\overrightarrow{0} \\
\dot{0} \\
\dot{0} \\
\dot{1} \\
\end{array}$ & 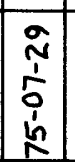 & 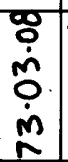 & $\begin{array}{l}\frac{5}{1} \\
\dot{d} \\
\dot{1} \\
\dot{n}\end{array}$ & $\begin{array}{l}+ \\
0 \\
\dot{0} \\
0 \\
\dot{0} \\
\dot{1}\end{array}$ \\
\hline 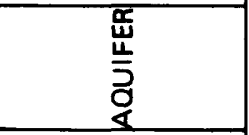 & $\vec{u}$ & $\sum_{\substack{0\\
}}^{\infty}$ & $\sum_{0}^{0}$ & $\sum_{\underline{\alpha}}^{\infty}$ & 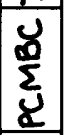 & & $\begin{array}{c}0 \\
\sum \\
\vdots \\
0 \\
2\end{array}$ & $\sum_{\substack{0 \\
0}}^{0}$ & $\sum_{0}^{0}$ & 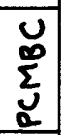 & $\frac{a}{4}$ & $\sum_{0}^{\infty}$ & ¿ूu & $\begin{array}{l}0 \\
\vdots \\
\\
\end{array}$ & & $\sum_{\substack{0 \\
\vdots}}^{0}$ & $\sum_{\substack{\infty \\
\alpha}}^{\infty}$ & 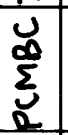 & & $\sum_{0}^{0}$ \\
\hline 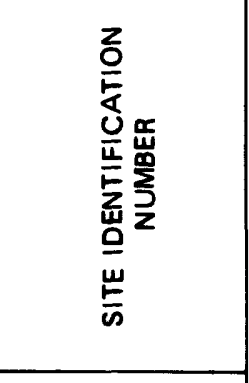 & $\begin{array}{c}8 \\
x \\
m \\
\infty \\
n \\
n \\
0 \\
m \\
n \\
m \\
0 \\
m\end{array}$ & $\begin{array}{l}8 \\
0 \\
n \\
\infty \\
\bar{n} \\
0 \\
\bar{n} \\
n \\
n \\
n \\
a \\
n\end{array}$ & 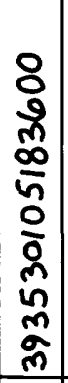 & 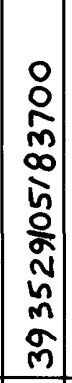 & $\begin{array}{c}o \\
0 \\
0 \\
m \\
o \\
\frac{0}{n} \\
\frac{0}{\infty} \\
\tilde{N} \\
\tilde{m} \\
m \\
\tilde{m} \\
\end{array}$ & & $\begin{array}{l}8 \\
0 \\
0 \\
N \\
\infty \\
n \\
0 \\
\tilde{n} \\
N \\
n \\
m \\
\cdots \\
m\end{array}$ & 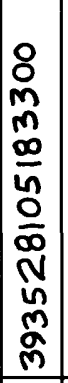 & 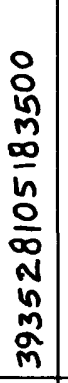 & $\begin{array}{l}8 \\
0 \\
N \\
m \\
\infty \\
n \\
o \\
\frac{n}{n} \\
N \\
\tilde{n} \\
m \\
\tilde{m} \\
m\end{array}$ & 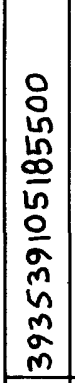 & 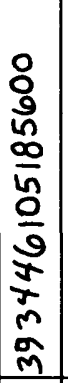 & 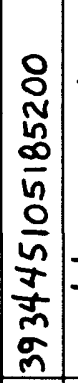 & 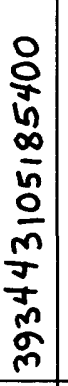 & & 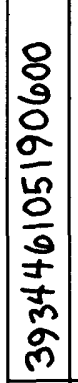 & 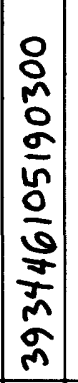 & $\begin{array}{l}8 \\
0 \\
n \\
0 \\
\sigma \\
n \\
0 \\
0 \\
m \\
\pm \\
\pm \\
m \\
\sigma \\
m\end{array}$ & & 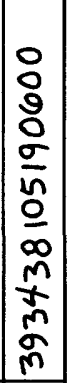 \\
\hline 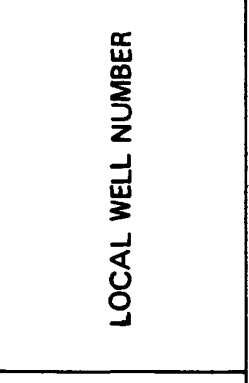 & 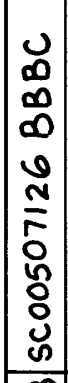 & 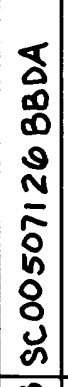 & $\begin{array}{l}\overline{0} \\
0 \\
\infty \\
0 \\
0 \\
N \\
\bar{\sigma} \\
0 \\
h \\
0 \\
0 \\
0 \\
0\end{array}$ & 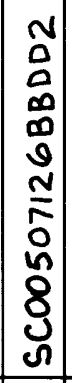 & 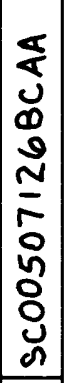 & & 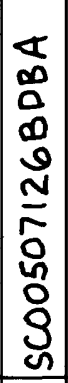 & \begin{tabular}{|c|c}
0 \\
0 \\
0 \\
0 \\
0 \\
0 \\
$N$ \\
$N$ \\
$T$ \\
0 \\
$n$ \\
0 \\
0 \\
$u$ \\
$n$ \\
\end{tabular} & 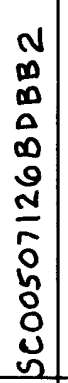 & 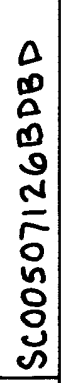 & 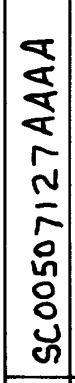 & 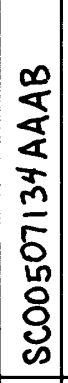 & 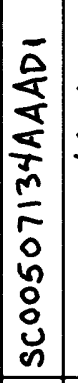 & 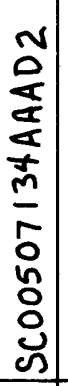 & & 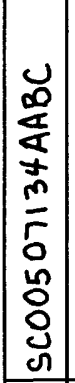 & 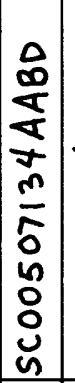 & 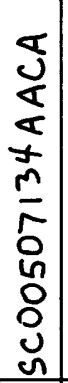 & & 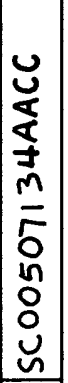 \\
\hline 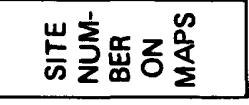 & 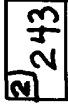 & $\begin{array}{l}n \\
\tilde{n} \\
\sim \\
\sim\end{array}$ & $\underset{w}{\tilde{w}}$ & $\begin{array}{l}0 \\
3 \\
\end{array} \mid$ & 节 & & $\begin{array}{l}n \\
\text { N }\end{array}$ & 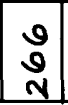 & $\stackrel{\mathfrak{N}}{\mathbf{N}}$ & $\frac{1}{N}$ & $\bar{n}$ & $\overline{0}$ & \begin{tabular}{|l|} 
\\
$m$ \\
0 \\
$m$
\end{tabular} & 志 & & $\begin{array}{l}n \\
0 \\
m\end{array}$ & ले & ô & & o \\
\hline
\end{tabular}




\begin{tabular}{|c|c|c|c|c|c|c|c|c|c|c|c|c|c|c|c|c|c|c|c|c|}
\hline 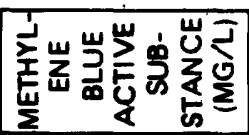 & $\begin{array}{l}8 \\
0 \\
0\end{array}$ & : & 웅. & ㅇ & 8 & 8 & 웅. & 웅 & 1 & 웅 & 웅. & $\stackrel{\circ}{\circ}$ & 8 & 8 & 응 & 8 & 1 & 웅 & 우 & ? \\
\hline 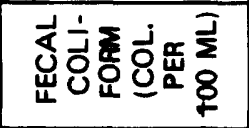 & $\bar{v}$ & $\bar{v}$ & $\bar{v}$ & $\bar{v}$ & $\bar{v}$ & $\bar{v}$ & $\begin{array}{l}\bar{v} \\
7\end{array}$ & $\bar{v}$ & 1 & $\bar{v}$ & $\bar{v}$ & $\bar{v}$ & $\bar{v}$ & $\bar{v}$ & $\bar{v}$ & $\begin{array}{l}\bar{v} \\
G\end{array}$ & 1 & $\bar{v}$ & $\bar{v}$ & $\bar{v}$ \\
\hline 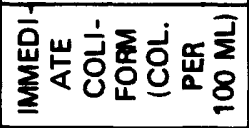 & $\bar{v}$ & $\bar{v}$ & $\bar{v}$ & $\bar{v}$ & $\bar{v}$ & $\bar{v}$ & $\bar{v}$ & $\begin{array}{l}\bar{v} \\
\bar{y}\end{array}$ & 1 & $\bar{v}$ & $\bar{v}$ & $\bar{v}$ & $\bar{v}$ & $\bar{v}$ & $\bar{v}$ & $\bar{v}$ & 1 & $\bar{v}$ & $\bar{v}$ & $\bar{v}$ \\
\hline 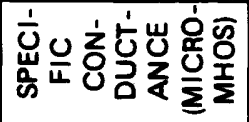 & $\begin{array}{l}0 \\
x \\
N\end{array}$ & $\underline{n}$ & 이 & $\frac{O}{N}$ & 옷 & 品 & Oे & 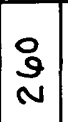 & 옷 & 䀡 & in & ¿ั & $\stackrel{\text { D }}{N}$ & \& & $\begin{array}{l}n \\
0 \\
\text { N }\end{array}$ & gn & N్ & 운 & $\stackrel{8}{\stackrel{N}{N}}$ & 8 \\
\hline 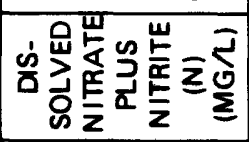 & $\begin{array}{c}n \\
0 \\
0\end{array}$ & in & $\stackrel{N}{=}$ & $\begin{array}{l}0 \\
0\end{array}$ & $\underline{n}$ & $\stackrel{\text { N }}{0}$ & $\overline{0}$ & $\overline{0}$ & 1 & $\begin{array}{c}N \\
0\end{array}$ & $\begin{array}{l}m \\
\infty \\
\infty\end{array}$ & $\sigma$ & $\begin{array}{l}N \\
O \\
O\end{array}$ & $\begin{array}{l}\infty \\
9\end{array}$ & $\infty$ & $\sqrt{3}$ & 1 & \pm & $\stackrel{n}{n}$ & n̊ \\
\hline 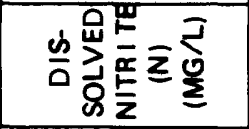 & ō & $\begin{array}{c}N \\
0\end{array}$ & $\overline{0}$ & 8 & 8 & $\overline{0}$ & 8 & 웅 & 1 & 오. & $\overline{0}$ & $\overline{0}$ & 음 & $\overline{0}$ & $\overline{0}$ & 응. & 1 & 8 & 8 & $\overline{0}$ \\
\hline 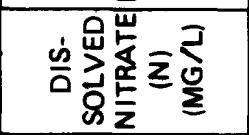 & $\stackrel{N}{N}$ & $\bar{n}$ & $\stackrel{N}{-}$ & 웅 & $\underline{n}$ & $\overline{0}$ & $\overline{0}$ & $\overline{0}$ & 1 & $\begin{array}{l}N \\
0 \\
0\end{array}$ & ִִ & $\stackrel{\infty}{0}$ & No & $\sqrt[3]{ }$ & $\tilde{m}$ & $\sqrt{9}$ & 1 & \pm & $\stackrel{n}{\stackrel{n}{*}}$ & 후 \\
\hline 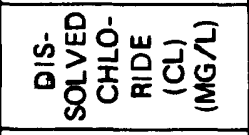 & $\stackrel{\circ}{m}$ & $\begin{array}{c}N \\
m\end{array}$ & $\stackrel{r}{N}$ & 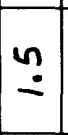 & $\stackrel{N}{N}$ & $=$ & $\stackrel{0}{\text { N }}$ & $\stackrel{m}{\stackrel{m}{*}}$ & 1 & $r$ & $\stackrel{N}{m}$ & $\stackrel{n}{-}$ & $\sigma$ & $\begin{array}{l}9 \\
\dot{m}\end{array}$ & $\stackrel{\infty}{-}$ & $\begin{array}{l}\infty \\
6 \\
6\end{array}$ & 1 & $\stackrel{9}{-}$ & $\stackrel{\infty}{-}$ & n' \\
\hline 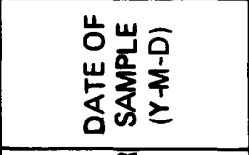 & 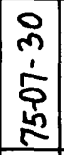 & $\begin{array}{c}\stackrel{m}{\dot{s}} \\
\dot{\dot{n}} \\
\dot{n}\end{array}$ & 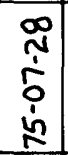 & 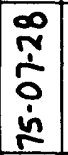 & 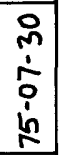 & 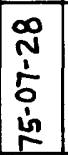 & $\begin{array}{l}n \\
\frac{1}{1} \\
\frac{1}{1}\end{array}$ & $\begin{array}{l}\bar{n} \\
\dot{o} \\
\dot{1} \\
\end{array}$ & $\begin{array}{l}\tilde{N} \\
1 \\
0 \\
0 \\
1 \\
\\
\end{array}$ & $\begin{array}{l}\text { Lo } \\
\dot{0} \\
0 \\
\dot{0} \\
\dot{1}\end{array}$ & 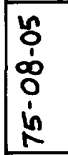 & $\begin{array}{l}n \\
N \\
\dot{5} \\
0 \\
\vdots \\
\end{array}$ & 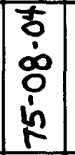 & 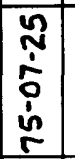 & \begin{tabular}{|c|}
\multirow{1}{*}{} \\
$\dot{1}$ \\
0 \\
$\dot{1}$ \\
\end{tabular} & $\frac{j}{1}$ & 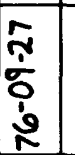 & $\begin{array}{l}m \\
\frac{m}{1} \\
0 \\
0 \\
\dot{0} \\
\dot{n}\end{array}$ & 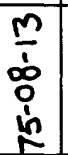 & $\begin{array}{l}\overline{1} \\
\dot{0} \\
\dot{1}\end{array}$ \\
\hline 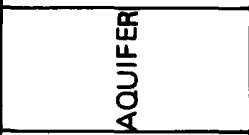 & $\sum_{0}^{\infty}$ & $\sum_{\substack{0 \\
\alpha \\
\alpha}}$ & $\sum_{\substack{\infty\\
}}^{\infty}$ & 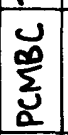 & $\sum_{\substack{0 \\
0}}^{0}$ & $\sum_{2}^{\infty}$ & $\sum_{\substack{0 \\
0}}^{0}$ & $\sum_{\alpha}^{\infty}$ & & $\sum_{0}^{\infty}$ & $\sum_{j}^{0}$ & $\sum_{0}^{\infty}$ & 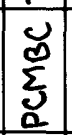 & $\sum_{0}^{0}$ & $\sum_{0}^{\infty}$ & $\sum_{\substack{\infty \\
\alpha}}^{\infty}$ & & 造 & $\sum_{0}^{\infty}$ & $\sum_{\substack{0 \\
2}}^{\infty}$ \\
\hline 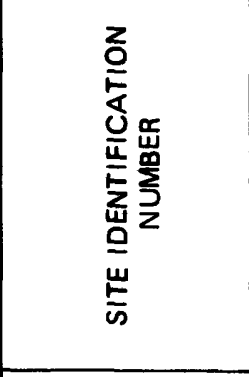 & 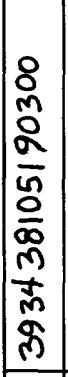 & $\begin{array}{l}8 \\
o \\
n \\
\infty \\
\frac{n}{n} \\
0 \\
0 \\
\frac{1}{d} \\
m \\
\tilde{m} \\
\end{array}$ & 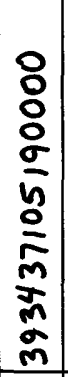 & $\begin{array}{l}8 \\
8 \\
\sigma \\
\bar{n} \\
0 \\
\frac{n}{n} \\
\frac{7}{2} \\
\frac{m}{m} \\
\bar{m} \\
\end{array}$ & 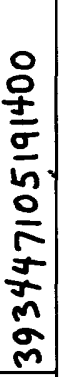 & 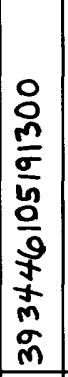 & 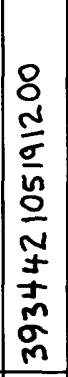 & 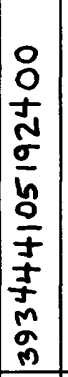 & & 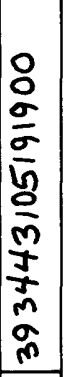 & 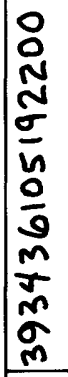 & 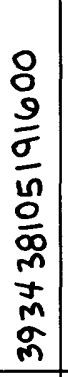 & 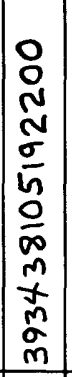 & 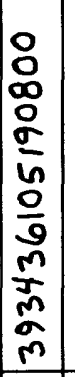 & 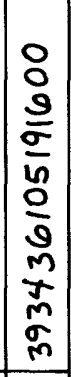 & 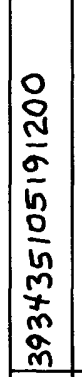 & & 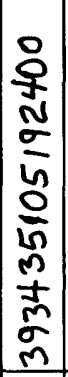 & 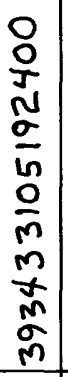 & 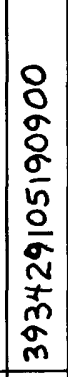 \\
\hline 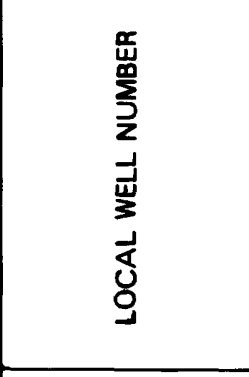 & 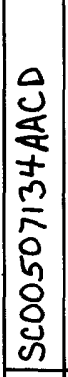 & 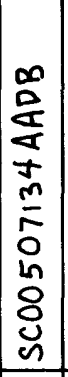 & 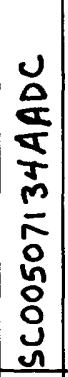 & 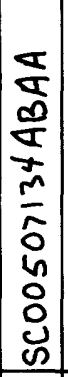 & 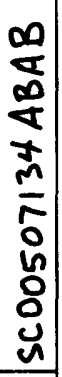 & 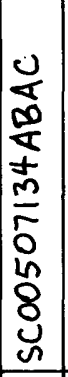 & 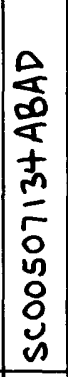 & 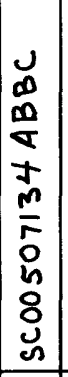 & & 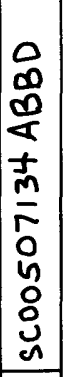 & 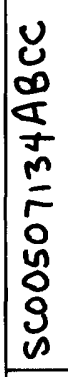 & 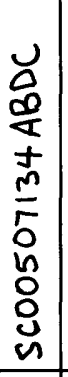 & $\begin{array}{l}0 \\
0 \\
0 \\
\frac{0}{4} \\
m \\
\frac{m}{5} \\
0 \\
n \\
0 \\
0 \\
u \\
n\end{array}$ & 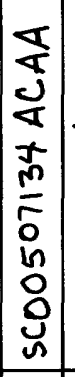 & 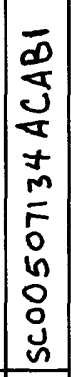 & 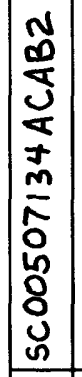 & & $\begin{array}{l}0 \\
\infty \\
0 \\
0 \\
u \\
m \\
\Gamma \\
0 \\
0 \\
0 \\
0 \\
0 \\
0\end{array}$ & $\begin{array}{l}u \\
0 \\
u \\
\square \\
\pm \\
m \\
5 \\
0 \\
6 \\
0 \\
0 \\
0 \\
0\end{array}$ & 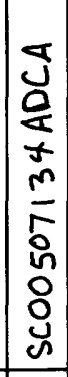 \\
\hline 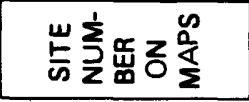 & $\frac{0}{m}$ & $\frac{N}{m}$ & $\frac{m}{m}$ & $\frac{n}{m}$ & $\frac{\theta}{m}$ & $\frac{r}{m}$ & $\frac{\infty}{m}$ & $\frac{a}{m}$ & & 怘 & $\bar{N}$ & $\begin{array}{l}N \\
N \\
m\end{array}$ & \begin{tabular}{|l|} 
\\
$N$ \\
$m$ \\
$m$
\end{tabular} & $\mid \begin{array}{c}* \\
\text { ñ } \\
n\end{array}$ & $\begin{array}{l}n \\
m\end{array}$ & $\begin{array}{c}\text { N } \\
\text { m } \\
\end{array}$ & & N & $\begin{array}{l}\infty \\
N \\
n\end{array}$ & a \\
\hline
\end{tabular}




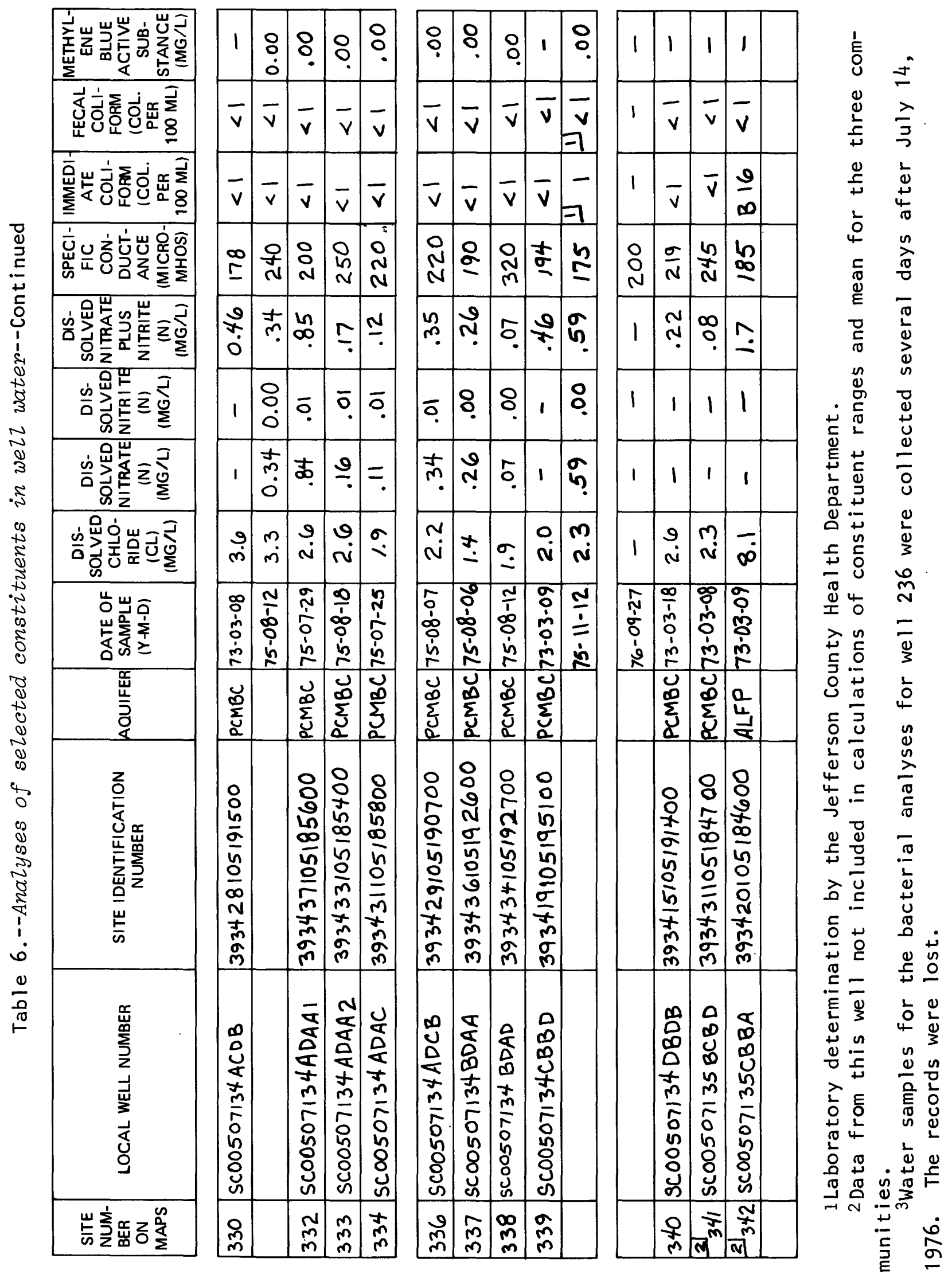



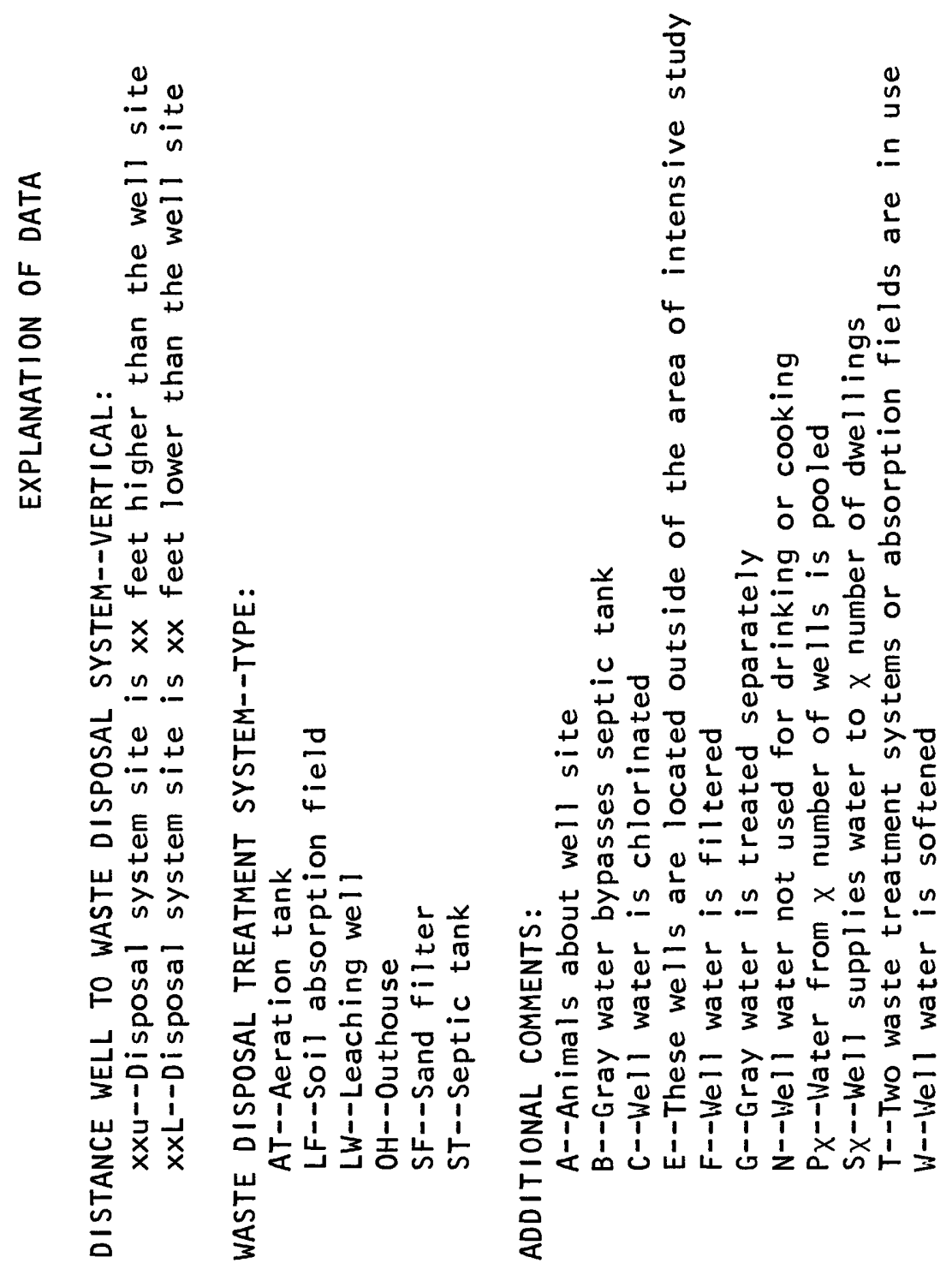


\begin{tabular}{|c|c|c|c|c|c|c|c|c|c|c|c|c|c|c|c|c|c|c|c|c|c|}
\hline \multicolumn{2}{|l|}{ 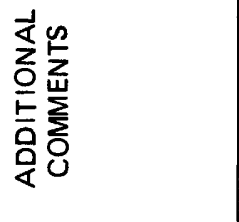 } & & & & $\gtrless$ & $\tau$ & & & & $\begin{array}{l}0 \\
N \\
2\end{array}$ & $\begin{array}{l}0 \\
\tilde{a}\end{array}$ & $\begin{array}{l}N \\
n \\
0\end{array}$ & & 0 & & $\varangle$ & & & & & $\varangle$ \\
\hline \multirow{4}{*}{ 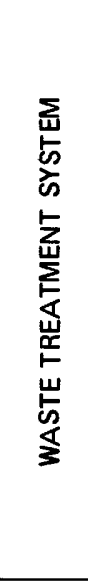 } & 离离岙 & 1 & 1 & 1 & 1 & 1 & 1 & $\stackrel{0}{1}$ & $b$ & 잉 & & $\mathfrak{G}$ & $n$ & 1 & 웅 & 1 & $\infty$ & $\stackrel{m}{r}$ & 1 & $\begin{array}{l}m \\
g\end{array}$ & $\begin{array}{l}0 \\
9\end{array}$ \\
\hline & 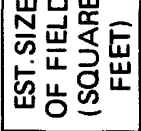 & 1 & $\begin{array}{l}8 \\
0 \\
9\end{array}$ & 1 & 1 & 1 & 응 & $\begin{array}{l}0 \\
0\end{array}$ & 1 & $\frac{2}{\sigma}$ & 1 & : & 1 & $\frac{b}{b}$ & $\begin{array}{l}8 \\
8\end{array}$ & $\begin{array}{l}8 \\
0 \\
0\end{array}$ & 이 & N & 1 & $\begin{array}{l}0 \\
N\end{array}$ & $\frac{n}{9}$ \\
\hline & 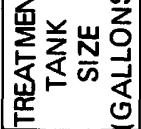 & 1 & 1 & 웅 & 음 & 1 & 1 & 1 & 1 & 8 & 1 & 8 & 1 & 1 & 요 & 8 & : & 1 & 1 & 요 & 8 \\
\hline & $\sum_{i}^{u}$ & T & $\begin{array}{l}\frac{4}{1} \\
\frac{1}{n}\end{array}$ & $\begin{array}{l}3 \\
\frac{3}{5} \\
5\end{array}$ & $\frac{3}{\frac{1}{5}}$ & $\frac{3}{1}$ & $\frac{4}{5}$ & $\frac{4}{5}$ & $\begin{array}{l}\frac{4}{1} \\
\frac{1}{n}\end{array}$ & $\frac{\frac{1}{1}}{\frac{1}{n}}$ & 1 & $\begin{array}{l}4 \\
\frac{1}{n} \\
n\end{array}$ & $\frac{4}{\frac{1}{n}}$ & $\frac{u}{5}$ & $\begin{array}{l}y \\
5 \\
5\end{array}$ & $\begin{array}{l}\frac{2}{1} \\
\frac{1}{5} \\
5\end{array}$ & $\frac{4}{5}$ & $\frac{n}{\frac{1}{n}}$ & $\frac{4}{1}$ & $\begin{array}{l}u \\
\frac{1}{2} \\
\frac{1}{n}\end{array}$ & $\frac{4}{\frac{1}{5}}$ \\
\hline \multirow{2}{*}{ 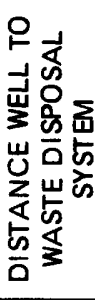 } & 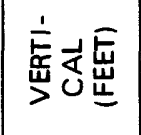 & $\begin{array}{l}0 \\
N \\
i\end{array}$ & $\begin{array}{l}0 \\
\sigma\end{array}$ & $\dot{\sigma}$ & $\begin{array}{l}0 \\
\tilde{m}\end{array}$ & $\begin{array}{l}0 \\
0 \\
i\end{array}$ & $\begin{array}{l}0 \\
\dot{\theta}\end{array}$ & $\begin{array}{l}0 \\
6 \\
7\end{array}$ & $\begin{array}{l}\dot{a} \\
\dot{r} \\
\dot{r}\end{array}$ & $\begin{array}{l}a \\
\dot{\sigma} \\
\sigma\end{array}$ & $\begin{array}{l}0 \\
J \\
\infty\end{array}$ & $\begin{array}{l}\dot{\phi} \\
\dot{\phi}\end{array}$ & $\begin{array}{l}0 \\
\infty \\
7\end{array}$ & $\stackrel{0}{*}$ & $\begin{array}{c}0 \\
\infty \\
\sigma\end{array}$ & 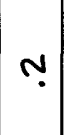 & $\begin{array}{l}A \\
\stackrel{m}{\dot{ }}\end{array}$ & $\begin{array}{l}0 \\
\dot{0} \\
\dot{2}\end{array}$ & $\begin{array}{l}0 \\
b \\
m\end{array}$ & $\begin{array}{l}a \\
m \\
m\end{array}$ & $\begin{array}{l}0 \\
\sigma \\
\text { nj }\end{array}$ \\
\hline & 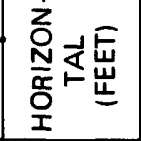 & 2 & ค & $\frac{b}{2}$ & $\stackrel{n}{m}$ & $\underline{n}$ & 으 & o & $\stackrel{\infty}{m}$ & $\hat{n}$ & $\frac{b}{x}$ & $\underline{\underline{6}}$ & 予 & 6 & 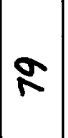 & $\vec{\infty}$ & $r$ & 9 & $\$$ & b & $\stackrel{m}{\sigma}$ \\
\hline \multirow{6}{*}{ 荘 } & 离离前 & $\pi$ & 1 & $\bar{\vartheta}$ & $\bar{\lambda}$ & $\begin{array}{l}0 \\
b\end{array}$ & $\begin{array}{l}\infty \\
h\end{array}$ & $\bar{r}$ & $b^{n}$ & $\pi$ & ○ & $\dot{n}^{m}$ & $n$ & $\stackrel{x}{\theta}$ & $b^{3}$ & $\hat{b}$ & $\infty$ & $\underset{r}{M}$ & 1 & N & $\hat{\vartheta}$ \\
\hline & 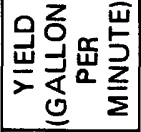 & $\stackrel{n}{n}$ & 1 & ? & $m$ & $\Lambda$ & 1 & $r$ & 1 & $¥$ & $m$ & - & $\vartheta$ & 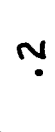 & $n$ & ? & 6 & $N$ & 1 & $n$ & ? \\
\hline & 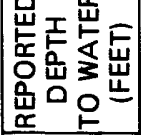 & 1 & 1 & $\$$ & 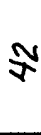 & 1 & 1 & $\tilde{b}$ & 1 & 은 & 1 & 1 & 1 & $\stackrel{N}{0}$ & 1 & 吉 & 만 & 1 & 1 & 1 & 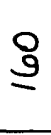 \\
\hline & 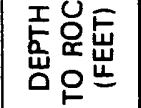 & R & 1 & $n$ & $N$ & 1 & 1 & $m$ & 1 & 우 & 1 & 1 & 1 & $\stackrel{\infty}{\mathbb{N}}$ & $\theta$ & $\mathbb{N}$ & 0 & 1 & 1 & N & 이 \\
\hline & 吾馬 & $\begin{array}{l}0 \\
n\end{array}$ & 1 & $\stackrel{\infty}{\infty}$ & $\stackrel{\mathrm{m}}{\mathrm{n}}$ & b & $\stackrel{\infty}{\infty}$ & $\stackrel{n}{2}$ & 1 & $\stackrel{n}{N}$ & 응 & $\underline{N}$ & 。 & $\frac{n}{n}$ & क & $\stackrel{n}{n}$ & 온 & 1 & 1 & $\stackrel{\infty}{=}$ & 方 \\
\hline & 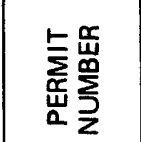 & 1 & 1 & $\frac{N}{\sigma}$ & \begin{tabular}{l}
$\sigma$ \\
$\infty$ \\
\multirow{2}{*}{}
\end{tabular} & 1 & 1 & $\frac{n}{3}$ & 1 & $\frac{\vec{N}}{\stackrel{N}{*}}$ & 1 & 1 & 1 & $\hat{\text { on }}$ & 1 & ఏ్ & $\begin{array}{l}7 \\
\sigma \\
\text { m } \\
m\end{array}$ & 1 & 1 & $\begin{array}{l}m \\
0 \\
m \\
N\end{array}$ & $\begin{array}{l}\infty \\
m \\
\frac{9}{m}\end{array}$ \\
\hline \multicolumn{2}{|c|}{ 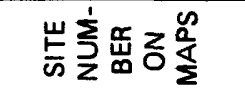 } & œ & o & $\stackrel{9}{0}$ & $\hat{0}$ & $\stackrel{\infty}{\circ}$ & $\stackrel{\circ}{ }$ & $\underline{ \pm}$ & $\stackrel{n}{=}$ & $\stackrel{\infty}{=}$ & & $\stackrel{\sigma}{=}$ & 오 & $\stackrel{N}{N}$ & $\stackrel{\mathbb{N}}{\underline{N}}$ & $\stackrel{n}{N}$ & $\stackrel{\infty}{\mathbb{N}}$ & $\underline{N}$ & 음 & $\underline{m}$ & $\stackrel{m}{m}$ \\
\hline
\end{tabular}




\begin{tabular}{|c|c|c|c|c|c|c|c|c|c|c|c|c|c|c|c|c|c|c|c|c|c|}
\hline 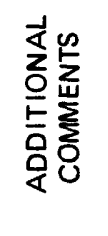 & & $\varangle$ & & & & & & $\begin{array}{l}n \\
\text { n }\end{array}$ & & & & & & $\begin{array}{l}u \\
0\end{array}$ & 3 & & & 0 & & & \\
\hline$\sum_{\mathbf{n}}$ & 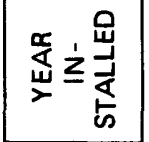 & hे & $\tilde{n}^{N}$ & $\sqrt[3]{5}$ & ? & 1 & $\widehat{N}$ & 1 & 8 & 1 & 1 & $\begin{array}{l}0 \\
9\end{array}$ & $\stackrel{m}{\vartheta}$ & $\frac{9}{2}$ & 1 & $\sqrt[3]{3}$ & 7 & $\frac{n}{2}$ & $\bar{T}$ & $\hat{b}$ & 1 \\
\hline $\begin{array}{l}5 \\
\frac{5}{5} \\
5 \\
\vdots \\
\Sigma\end{array}$ & 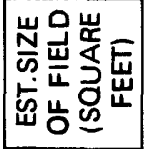 & 1 & : & $\begin{array}{l}8 \\
6 \\
6\end{array}$ & 1 & 1 & : & 1 & $\frac{6}{3}$ & $\begin{array}{l}0 \\
0 \\
6\end{array}$ & $\stackrel{ }{\circ}$ & 웅 & 1 & $\begin{array}{l}8 \\
8 \\
b\end{array}$ & $\begin{array}{l}0 \\
5 \\
5\end{array}$ & $\begin{array}{l}\infty \\
9 \\
4\end{array}$ & o & $\begin{array}{l}0 \\
0 \\
6\end{array}$ & 8 & 1 & 1 \\
\hline 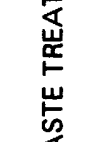 & 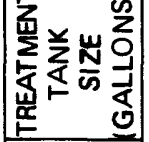 & : & 1 & 1 & 1 & 1 & $\begin{array}{l}0 \\
0 \\
0\end{array}$ & 1 & $\begin{array}{l}0 \\
0 \\
0 \\
0\end{array}$ & $\begin{array}{l}0 \\
0 \\
6\end{array}$ & 1 & 1 & 1 & 1 & 1 & $!$ & 1 & $\begin{array}{l}0 \\
0 \\
6\end{array}$ & 1 & 1 & 1 \\
\hline 3 & $\underset{⿱ u}{\stackrel{u}{Z}}$ & $\frac{n}{\frac{1}{n}}$ & $\begin{array}{l}\frac{4}{1} \\
\frac{1}{n}\end{array}$ & $\frac{4}{\frac{1}{5}}$ & $\frac{4}{5}$ & 1 & $\begin{array}{l}4 \\
\frac{1}{1} \\
5 \\
5\end{array}$ & $\frac{u}{1}$ & 告 & $\begin{array}{l}4 \\
\frac{1}{5} \\
5\end{array}$ & $\frac{4}{1}$ & $\frac{u}{5}$ & $\begin{array}{l}4 \\
1 \\
5 \\
5\end{array}$ & 占 & $\frac{4}{1}$ & $\frac{4}{\frac{1}{5}}$ & $\frac{4}{5}$ & $\frac{4}{5}$ & $\frac{4}{\frac{1}{5}}$ & $\frac{3}{1}$ & $\begin{array}{l}4 \\
1 \\
5 \\
5\end{array}$ \\
\hline \multirow{2}{*}{ 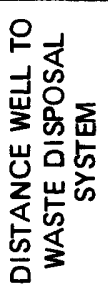 } & 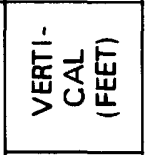 & a & $\begin{array}{l}0 \\
n \\
\sigma\end{array}$ & $\begin{array}{l}0 \\
0 \\
\infty\end{array}$ & 1 & $\stackrel{0}{i}$ & 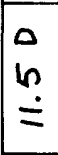 & 1 & $\stackrel{0}{n}$ & $\stackrel{a}{\ddot{N}}$ & $\begin{array}{l}0 \\
\infty \\
1\end{array}$ & $\begin{array}{l}0 \\
\dddot{N} \\
\ddot{s}\end{array}$ & כ & $\begin{array}{l}7 \\
0 \\
0 \\
7\end{array}$ & $\begin{array}{l}0 \\
\hat{0}\end{array}$ & $\begin{array}{c}\Delta \\
\theta \\
\dot{N}\end{array}$ & $\begin{array}{l}0 \\
0 \\
\sigma\end{array}$ & $\begin{array}{l}0 \\
9 \\
\vdots\end{array}$ & $\begin{array}{l}0 \\
\infty \\
\infty\end{array}$ & $\begin{array}{l}0 \\
\dot{m} \\
\dot{m}\end{array}$ & 1 \\
\hline & 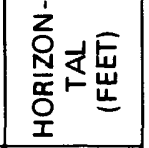 & mे & ñ & $\hat{n}$ & $\frac{h}{2}$ & $\stackrel{\infty}{\sim}$ & ق & 1 & 2 & $\stackrel{0}{2}$ & $\stackrel{\infty}{N}$ & $\stackrel{\infty}{=}$ & $\stackrel{:}{\stackrel{N}{N}}$ & $\begin{array}{l}m \\
n \\
N\end{array}$ & 5 & 웅 & $\stackrel{9}{m}$ & $\pi$ & $\stackrel{N}{=}$ & ต & 1 \\
\hline \multirow{6}{*}{ 岀 } & 离岕岙 & $\stackrel{x}{\lambda}$ & $\stackrel{N}{b}$ & $\overrightarrow{3}$ & $\ddot{\theta}$ & $b$ & $\stackrel{m}{9}$ & $\mathfrak{b}^{\infty}$ & 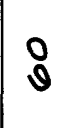 & 1 & $\begin{array}{l}N \\
n\end{array}$ & & 1 & $\hat{h}$ & o & $\sqrt{3}$ & $\stackrel{M}{n}$ & $n$ & $\bar{T}$ & $\hat{n}$ & 1 \\
\hline & 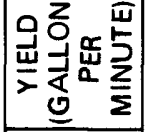 & $\begin{array}{l}n \\
N\end{array}$ & 1 & - & $?$ & - & 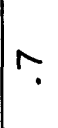 & $\stackrel{m}{\infty}$ & 1 & 1 & $\Gamma$ & $m$ & 1 & $\vartheta$ & $b$ & 1 & $M$ & 웅 & $n$ & - & 1 \\
\hline & 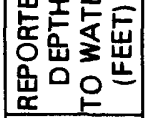 & 1 & 1 & $\bar{N}$ & $\frac{x}{x}$ & 1 & $\begin{array}{l}n \\
b\end{array}$ & 욕 & 1 & 1 & 1 & 1 & 1 & 1 & 1 & 1 & 1 & 1 & $\underset{7}{*}$ & $\underset{\infty}{N}$ & 1 \\
\hline & $\begin{array}{l}\text { I号点 } \\
\text { 岀인 }\end{array}$ & 9 & 1 & $\stackrel{\vec{v}}{v}$ & $m$ & 1 & $\infty$ & $\infty$ & 1 & 1 & 1 & 0 & 1 & 1 & 1 & 1 & 1 & 1 & 0 & $m$ & 1 \\
\hline & 秥馬 & $\begin{array}{l}\text { O } \\
\text { N }\end{array}$ & 요 & $\begin{array}{l}9 \\
3\end{array}$ & $\stackrel{n}{n}$ & $?$ & $\begin{array}{l}\infty \\
\mathfrak{v} \\
\sim\end{array}$ & $\stackrel{1}{1}$ & 응 & : & $\bar{m}$ & $\stackrel{N}{N}$ & $\stackrel{\text { N }}{ }$ & $\underline{h}$ & $\stackrel{0}{7}$ & 1 & $\frac{b}{x}$ & $\begin{array}{l}m \\
N \\
b\end{array}$ & $\begin{array}{l}0 \\
n \\
N\end{array}$ & $\stackrel{\infty}{=}$ & 1 \\
\hline & 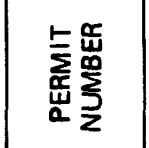 & 1 & 1 & 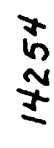 & $\begin{array}{l}N \\
0 \\
N \\
N\end{array}$ & 1 & ฐ & $\frac{n}{N}$ & 1 & 1 & 1 & $\begin{array}{l}\overline{8} \\
\text { m }\end{array}$ & 1 & 1 & 1 & 1 & 1 & 1 & $\begin{array}{c}a \\
\tilde{n} \\
m \\
0 \\
n\end{array}$ & $\frac{7}{n}$ & 1 \\
\hline$\frac{w}{\omega} \sum_{z}^{1}$ & $5 \geq \frac{2}{4}$ & $\tilde{m}$ & $\stackrel{\text { m }}{ }$ & กิ & 趈 & $\underline{\beta}$ & 오 & 企 & $\stackrel{m}{I}$ & $\hat{x}$ & 寽 & 음 & "n & N & $\overline{\mathbf{N}}$ & No & $\begin{array}{l}M \\
0 \\
0 \\
\text { N }\end{array}$ & $\begin{array}{l}7 \\
\text { ㄱ }\end{array}$ & $\begin{array}{l}n \\
0 \\
N\end{array}$ & กั & م \\
\hline
\end{tabular}




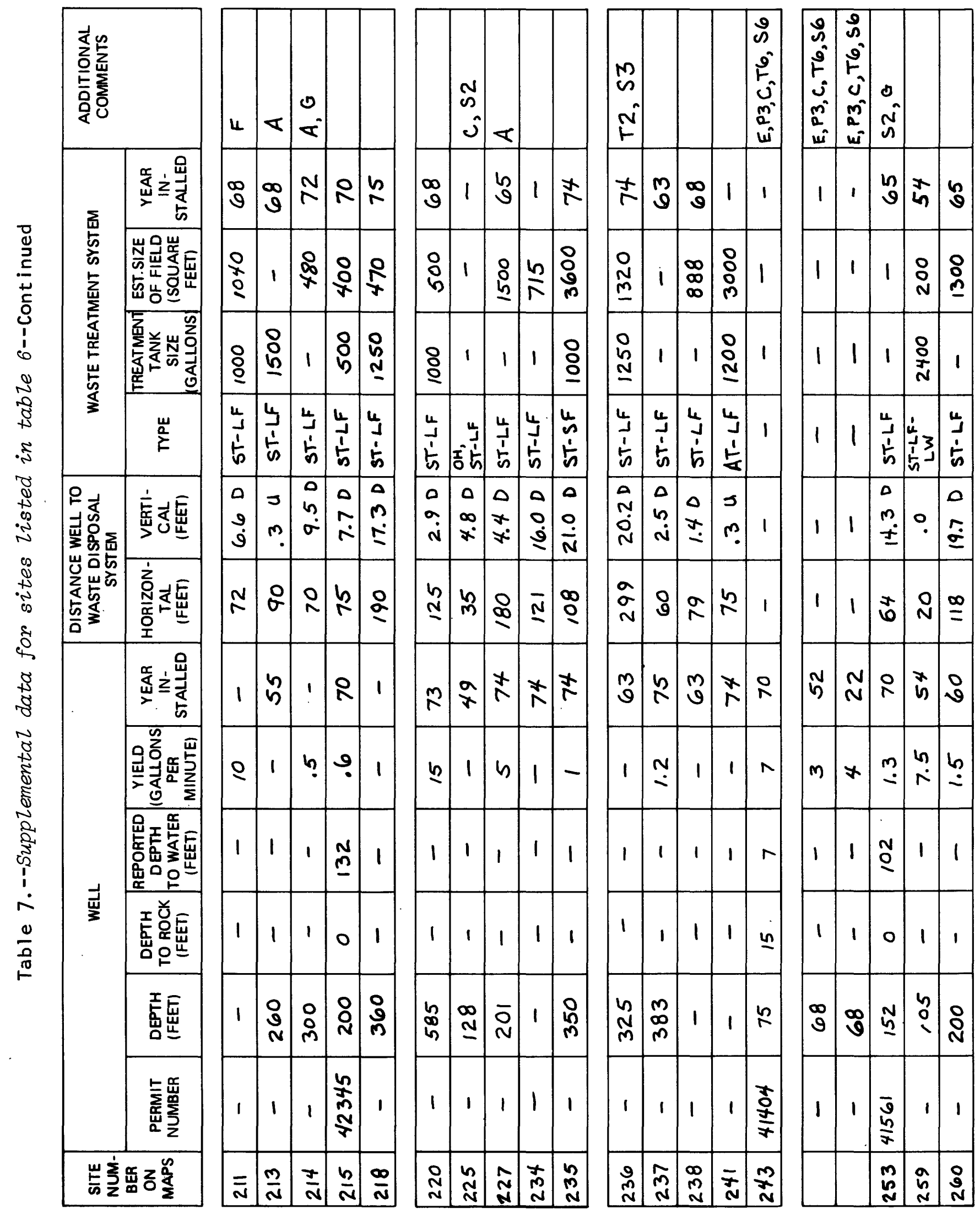




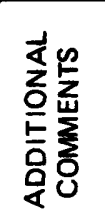

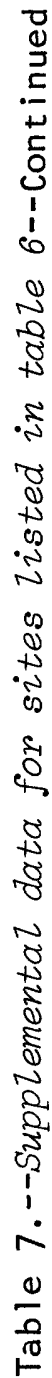

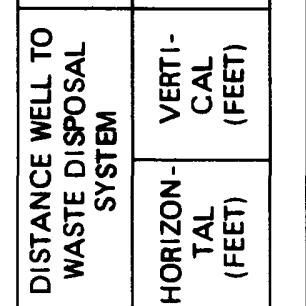

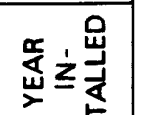

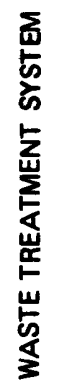

荝晨

कु

昰告兽

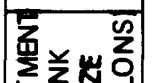

岁这的考

w

.

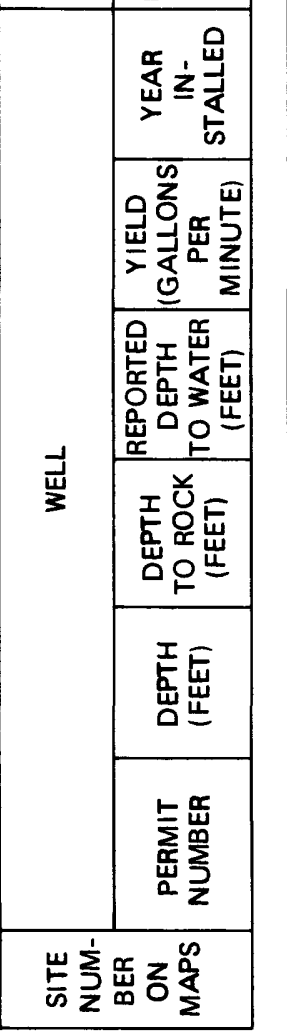

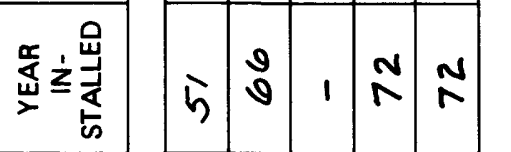

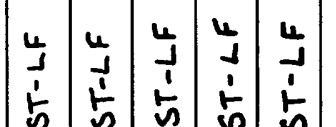

\begin{tabular}{lllll}
$\frac{5}{5}$ & $\frac{1}{5}$ & $\frac{5}{n}$ & $\frac{5}{5}$ & 5 \\
\hline
\end{tabular}

\begin{tabular}{lll|l|l|l|}
0 & 0 & 0 & 0 & 0 \\
$m$ & 0 & $m$ & 0 & 7
\end{tabular}

:

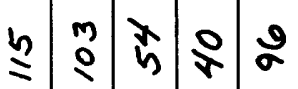

\begin{tabular}{|l|l|l|l|l|}
\hline & $b$ & 1 & $b$ & $N$ \\
\hline 1 & 1 & 1 & $⿱$ & 1 \\
\hline
\end{tabular}

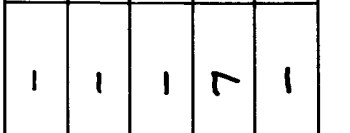

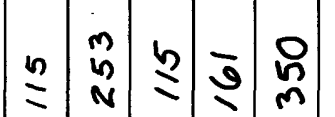

$\because N \geqslant \geqslant m$

\begin{tabular}{|c|c|c|c|c|}
\hline 1 & 1 & 1 & $\frac{\pi}{\frac{\pi}{m}}$ & 1 \\
\hline 离 & $\begin{array}{l}n \\
3 \\
r\end{array}$ & త్ & $\sqrt[3]{N}$ & $\frac{0}{N}$ \\
\hline
\end{tabular}

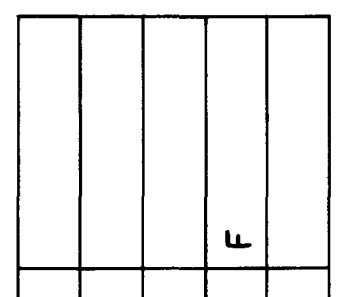

$\sin \frac{1}{n} \frac{1}{n} \frac{n}{n}$

\begin{tabular}{lll}
0 & 0 & 0 \\
9 & 0 & 0 \\
\hdashline & 9
\end{tabular}

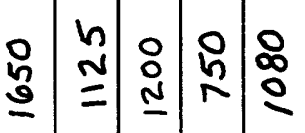

인 11 :

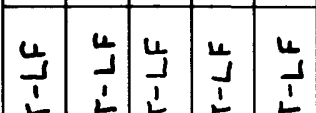

\begin{tabular}{lllll}
$\frac{1}{5}$ & $\frac{1}{5}$ & $\frac{1}{5}$ & $\frac{1}{5}$ & $\frac{1}{5}$ \\
\hline
\end{tabular}

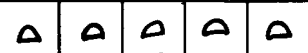

$m \sim \underset{m}{m} \stackrel{\sim}{\sim}$

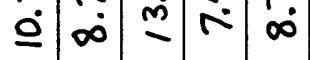

잉

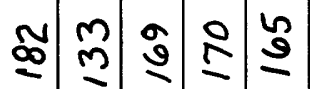

$n \frac{m}{n} N N$

N N $N \frac{N}{n}$

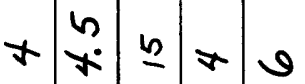

$\infty, m 1 \underline{n}$

\begin{tabular}{|l|l|l|l|l|}
\hline 1 & 1 & 8 & 1 & ำ \\
\hline
\end{tabular}

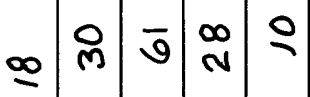

$\infty \quad \infty \leftleftarrows \infty-$

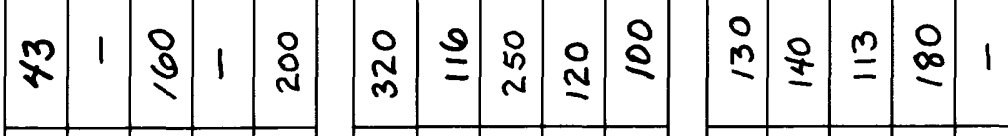

\begin{tabular}{|c|c|c|c|c|}
\hline 1 & 1 & 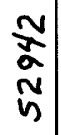 & 1 & 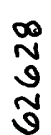 \\
\hline $\bar{N}$ & $\overline{\mathrm{m}}$ & $\begin{array}{l}m \\
0 \\
m\end{array}$ & 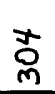 & $\begin{array}{l}n \\
o \\
m\end{array}$ \\
\hline
\end{tabular}

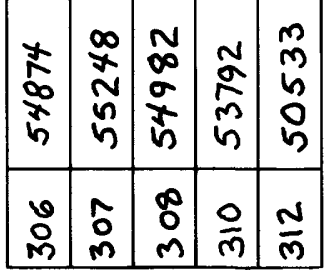

交学

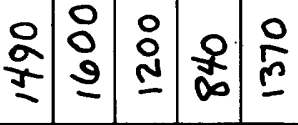

\begin{tabular}{lll|l|l}
$\circ$ & 0 & 0 & & \\
든 & $h$ & 5 & 1 & 8 \\
\hline
\end{tabular}

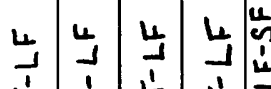

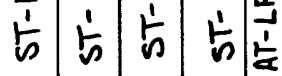

$\begin{array}{lllll}\Delta & 0 & \Delta & 0 & \Delta\end{array}$

-n n $n=\infty$

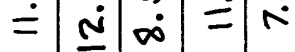

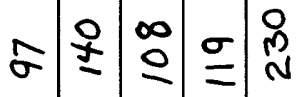

m N

$\theta \ln \frac{2}{n} \pi$

$1 \quad b \quad \bumpeq 111$

$m$ m

\begin{tabular}{|c|c|c|c|}
\hline & $\begin{array}{l}m \\
b \\
\infty \\
0 \\
b\end{array}$ & 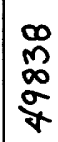 & 1 \\
\hline & $\frac{m}{m}$ & $\frac{9}{m}$ & $\frac{r}{m}$ \\
\hline
\end{tabular}

N 


\section{高器高}

ב

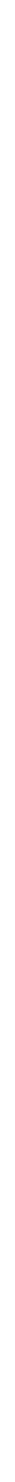
.

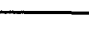

荘

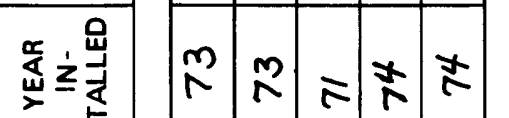

㟧虽

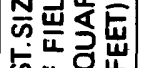

点岁要

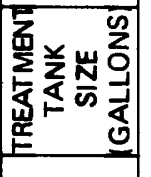

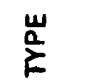

욜 底点焉

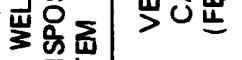

㟧司

这䋇

蛋豈

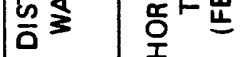

这之总

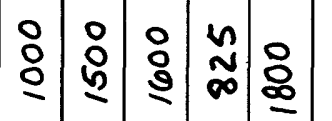

으음

峁

$\frac{1}{5} \frac{1}{5} \frac{1}{5} \frac{1}{5} \frac{1}{n}$

$\Delta \quad 00000$

$\begin{array}{lllll}0 & 0 & 1 & 0 & 0 \\ 0 & 0 & 0 & 0\end{array}$

$\dot{v} \hat{N} \doteq \dot{v}$

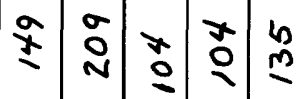

N $\frac{1}{2} \pi \frac{5}{3}$

क

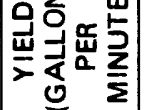

剧点畐

员挐

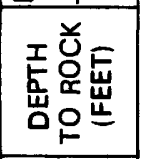

喜豆

产畄

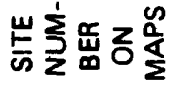

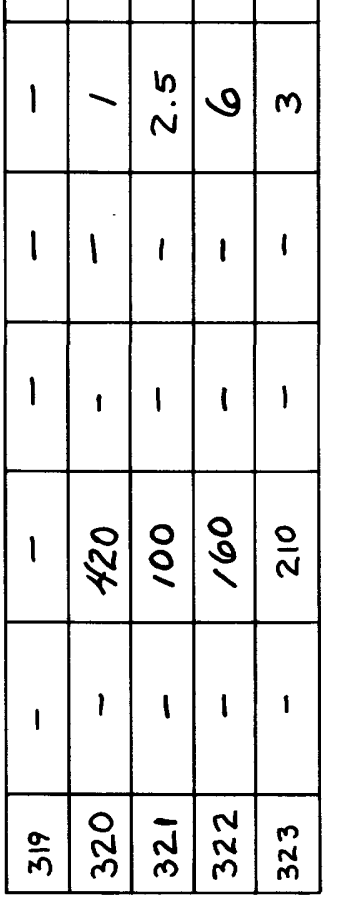

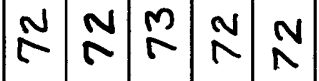

닌

는 1 영

岇蓪

\begin{tabular}{lllll}
$\frac{1}{5}$ & $\frac{1}{5}$ & $\frac{1}{n}$ & $\frac{1}{5}$ & $\frac{1}{5}$ \\
\hline
\end{tabular}

\begin{tabular}{lll|l|l|l|}
\hline & 0 & 0 & 0 & 0 \\
9 & $m$ & 0 & 9
\end{tabular}

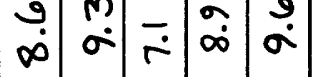

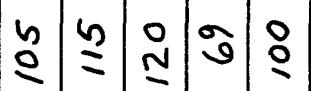

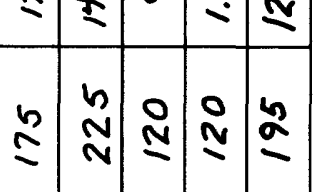

$:$\begin{tabular}{lllll}
$:$ & 8 & 1 & 1 & 8 \\
\hline
\end{tabular}

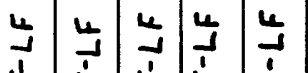

占

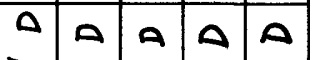

Ni

$m N N N N$

N $N N N$

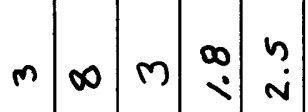

1

a 11

$1 \infty$

$\begin{array}{llll}\infty & 1 & 0 & 0 \\ N & & & \end{array}$

1

0의?

$\therefore$

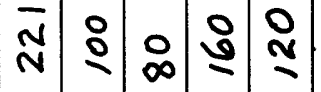

은

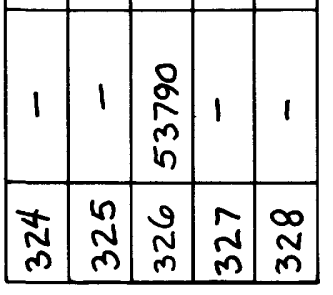

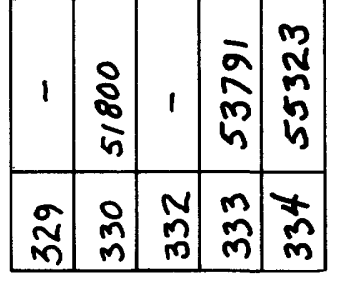

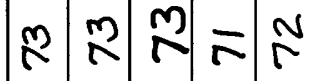
$\begin{array}{lllll}\therefore & & 0 & & \\ & \infty & n & 0 & 1\end{array}$ $\begin{array}{llllll}8 & 8 & 1 & 1 & 1\end{array}$

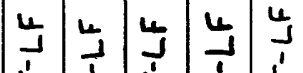
占京它客

$\begin{array}{llll}\triangle & A & \boldsymbol{A} & \triangle\end{array}$

?.

$\sigma=\stackrel{\circ}{\sim}$

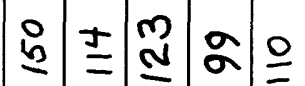

$\operatorname{n} \underset{m}{n} \bar{m}$

$\begin{array}{ll}n & n \\ m & j\end{array} m-\begin{aligned} & n \\ & N\end{aligned}$

$\begin{array}{lllll}5 & 1 & 1 & 2 & 1\end{array}$ $\begin{array}{lllll}n & 1 & 1 & 0 & 1\end{array}$

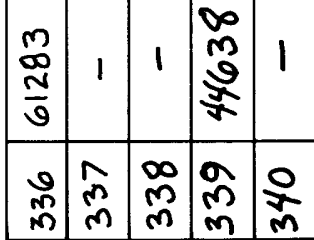




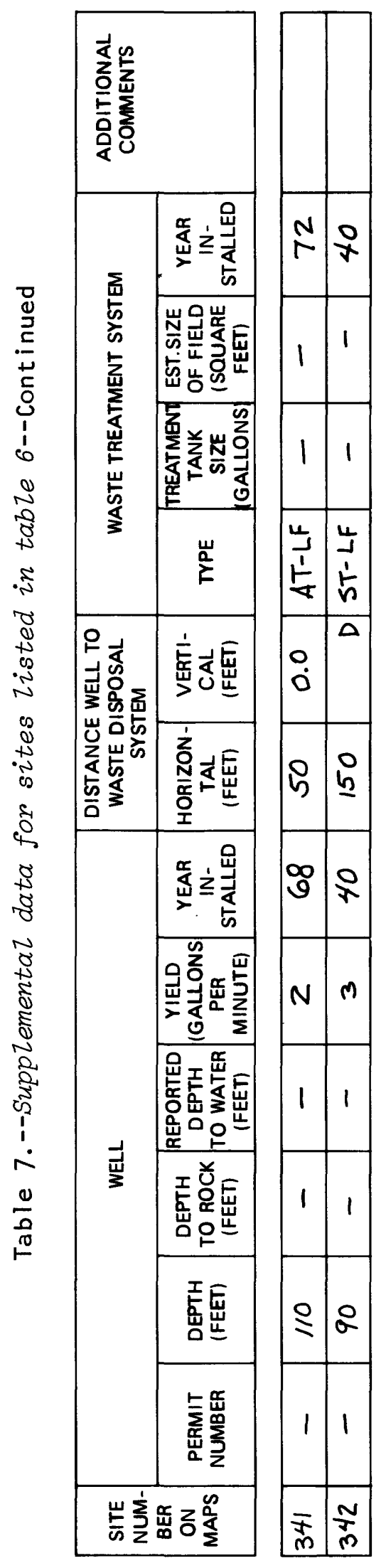


管

है

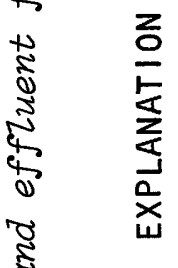

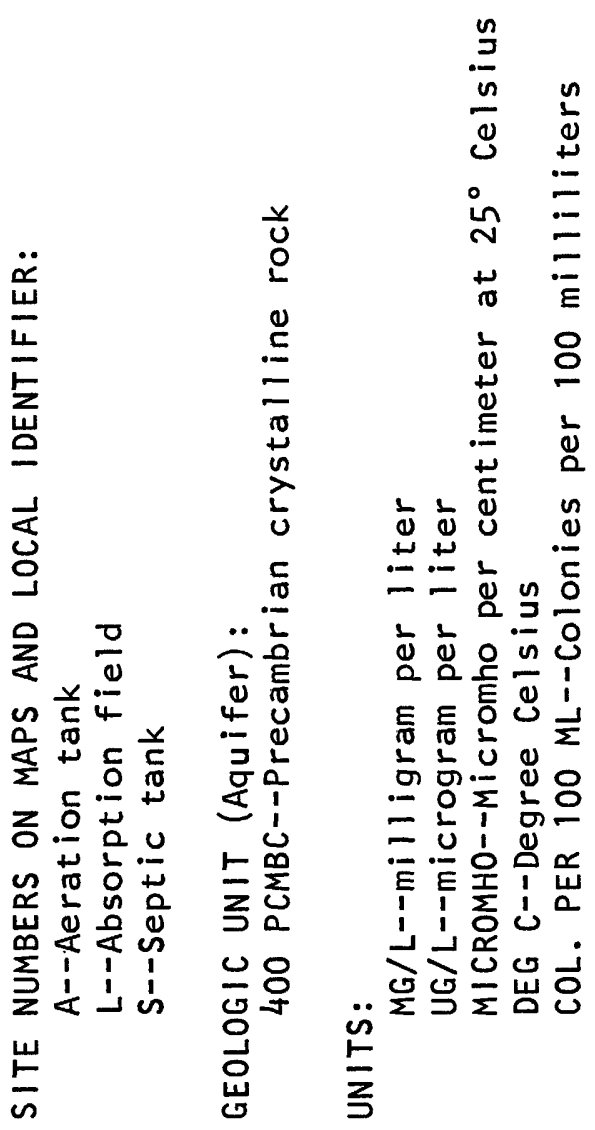




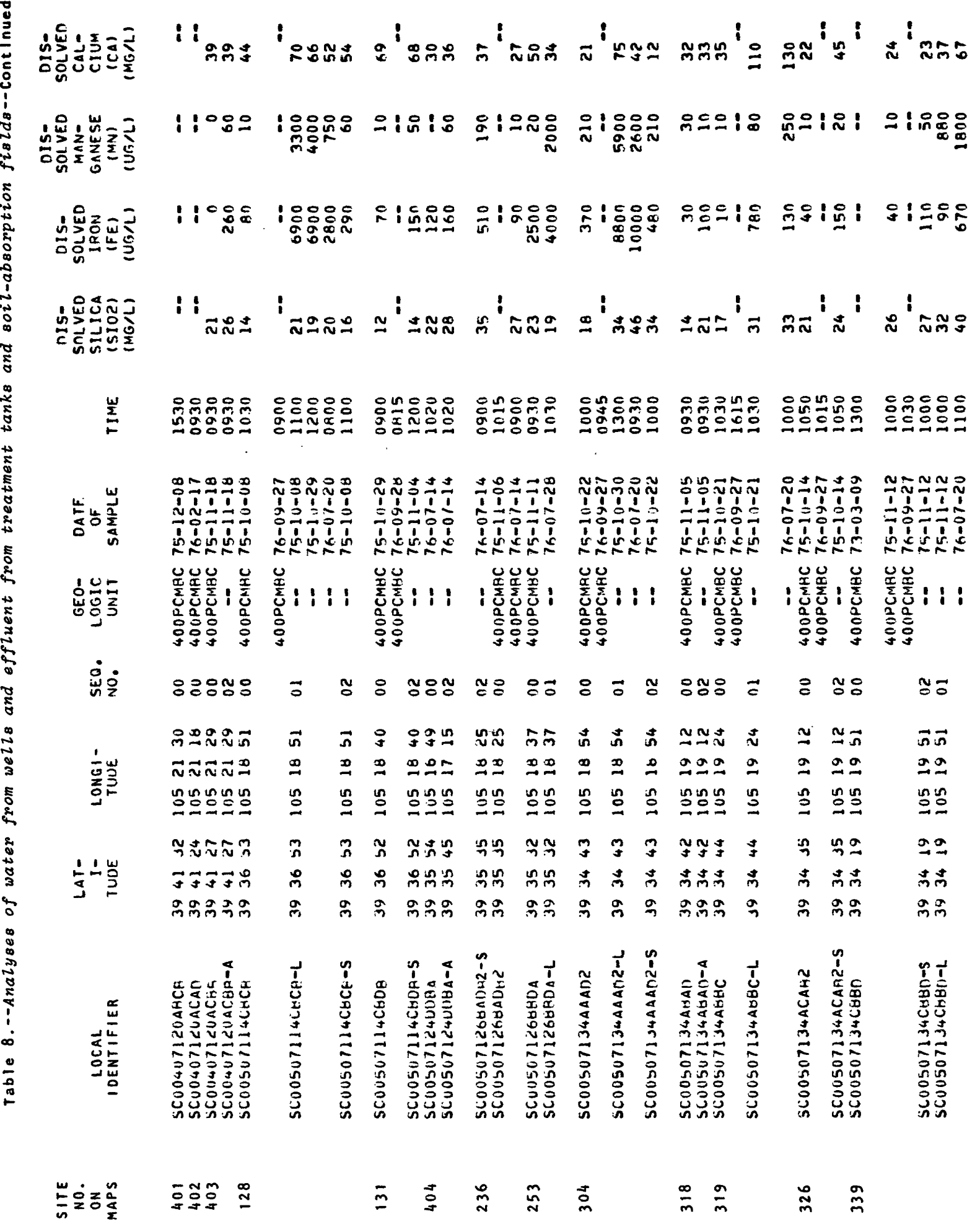




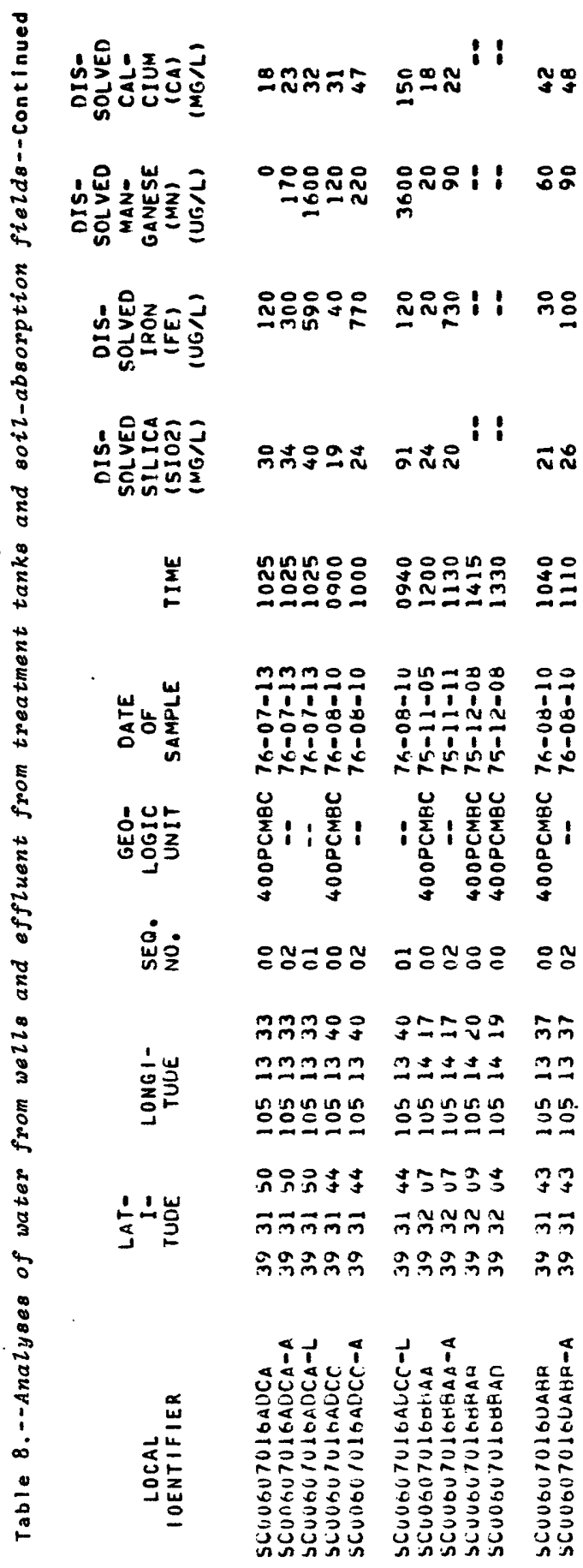

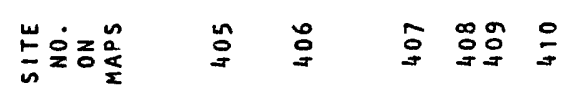




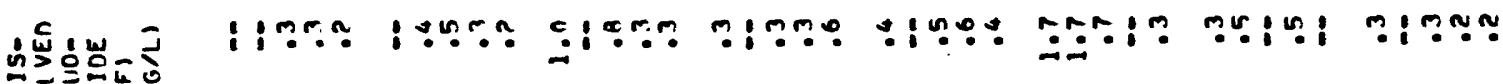

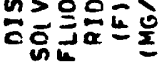

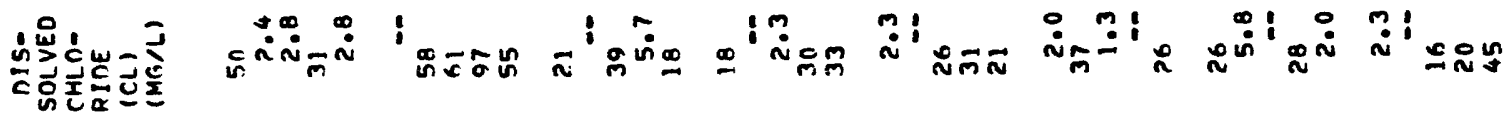

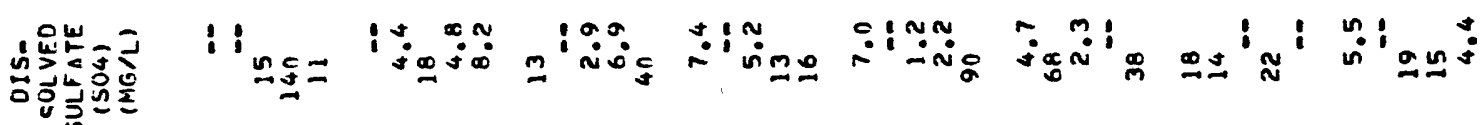

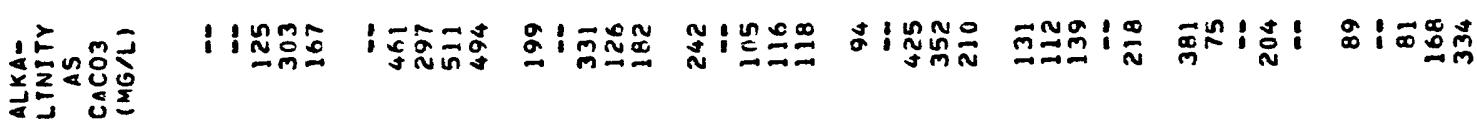

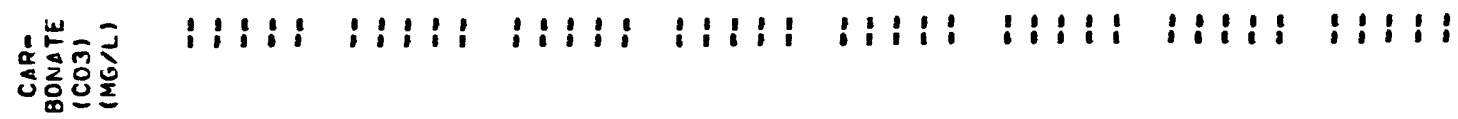

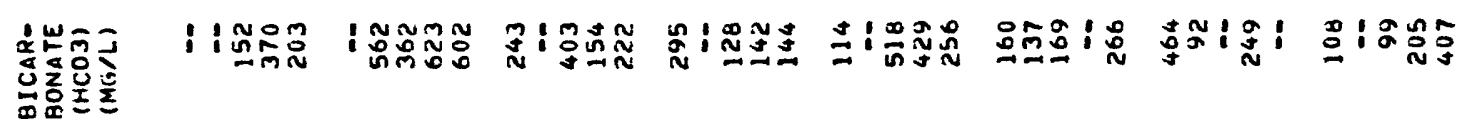

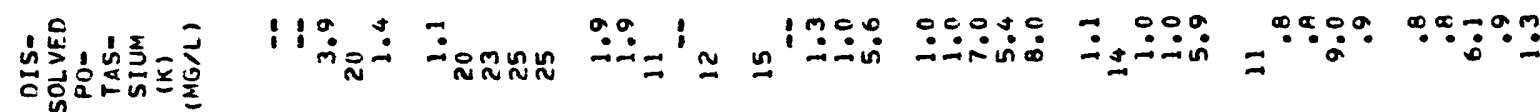

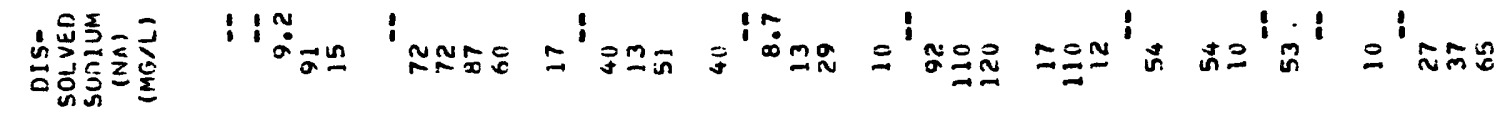

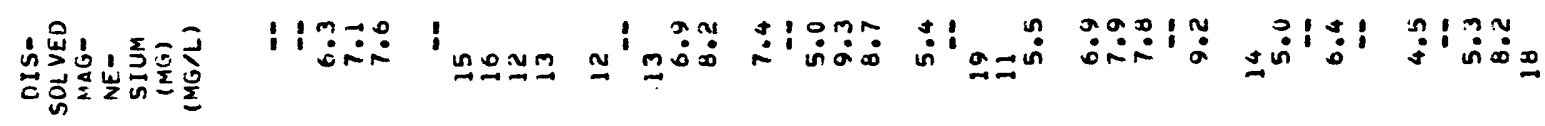

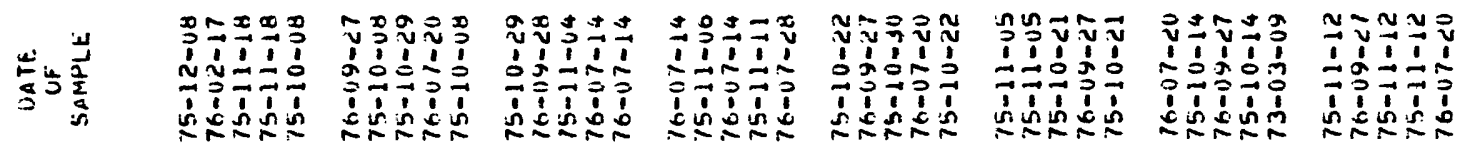

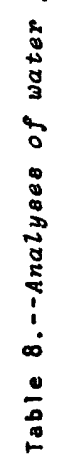

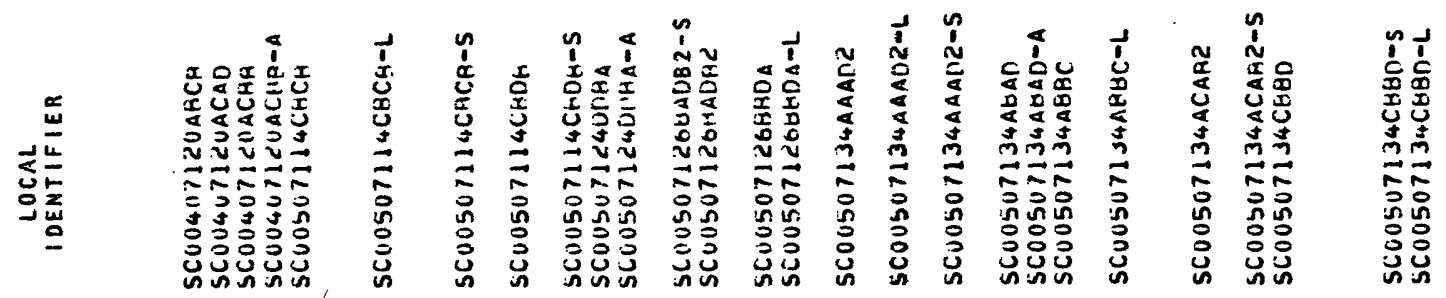

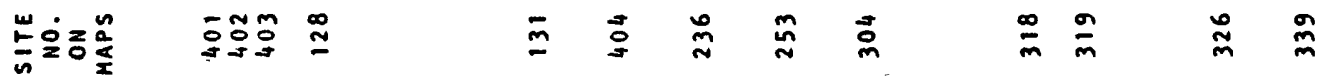




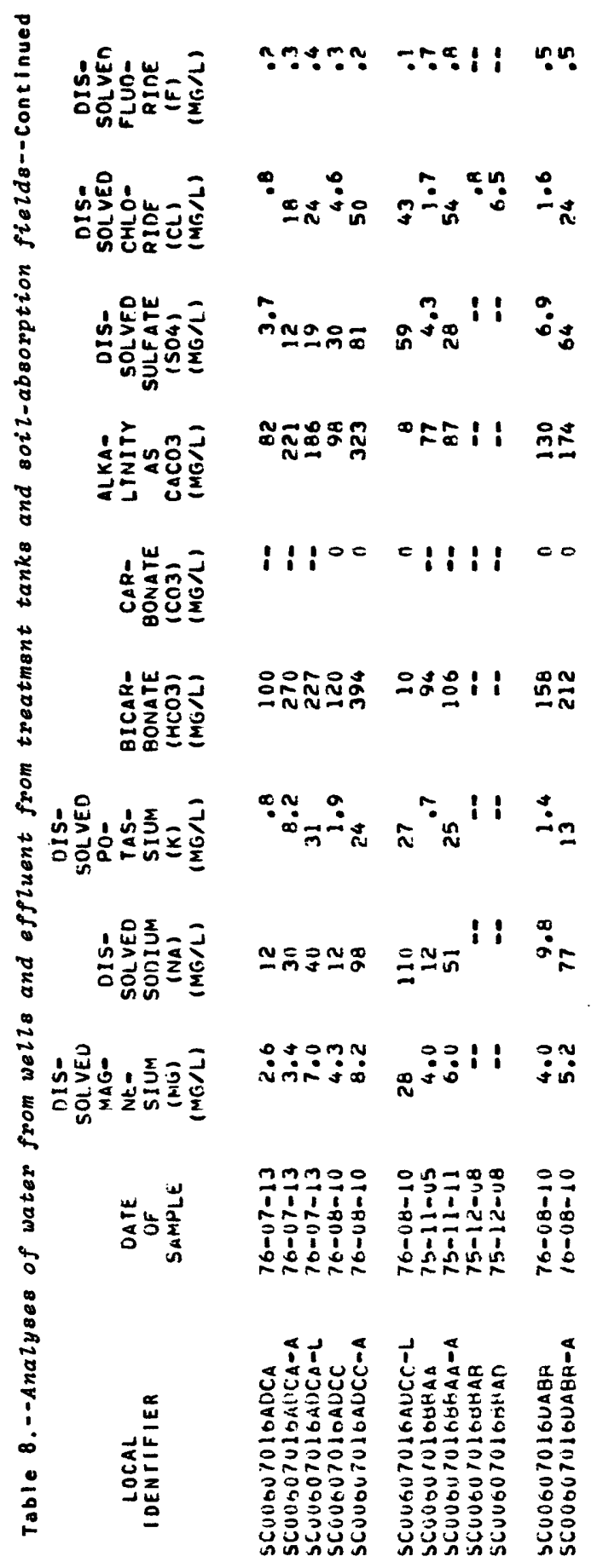

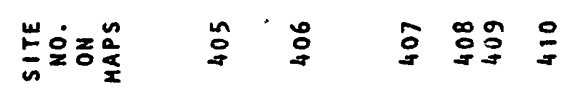


:

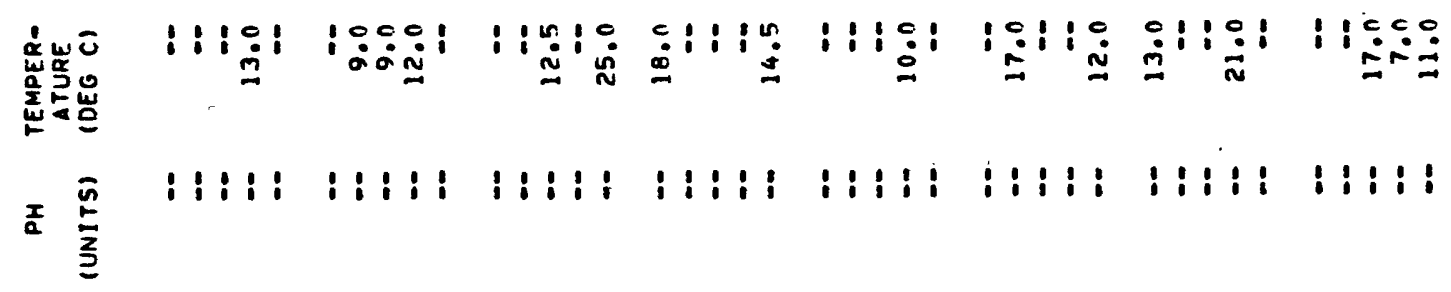

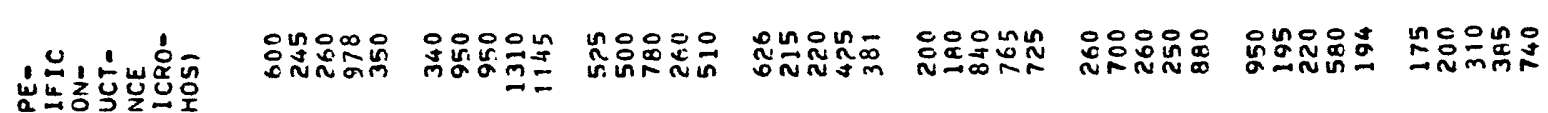

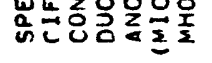

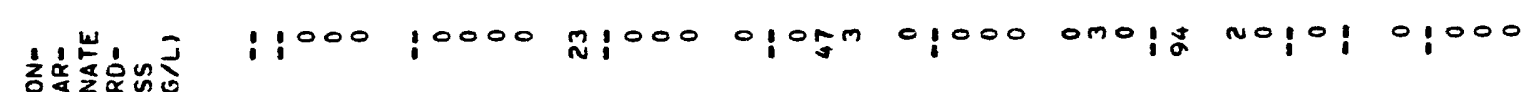

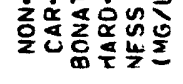

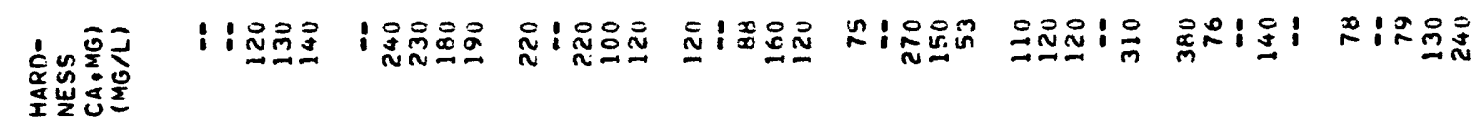

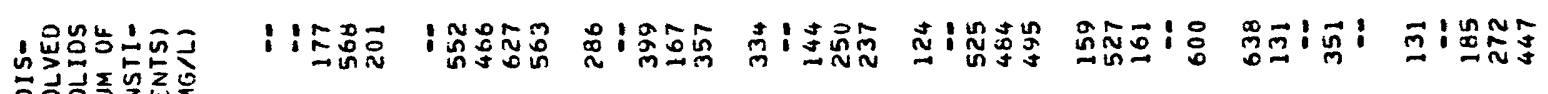

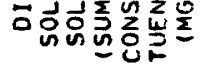

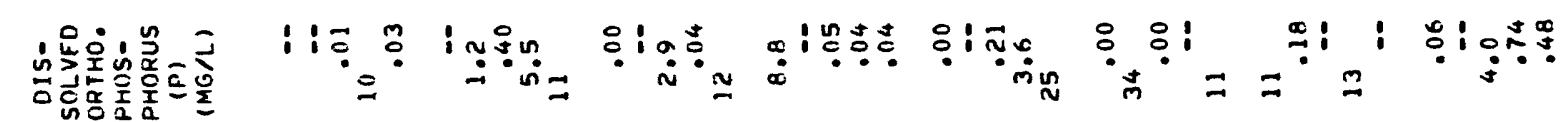

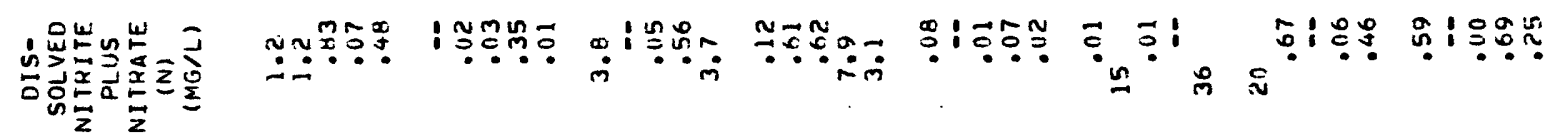

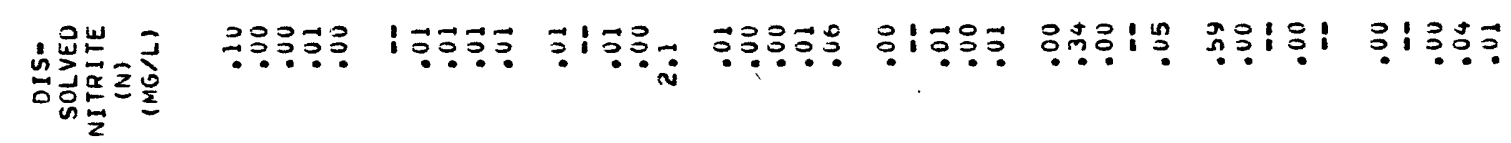

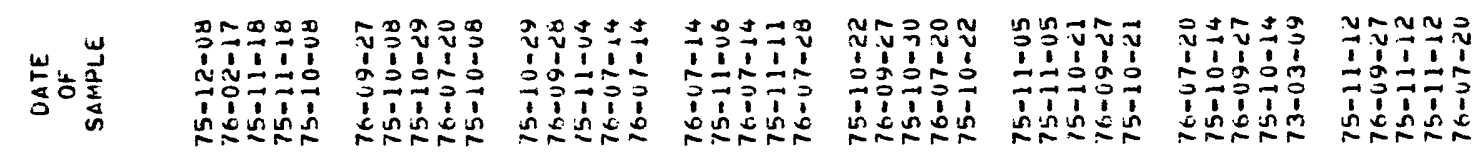

.

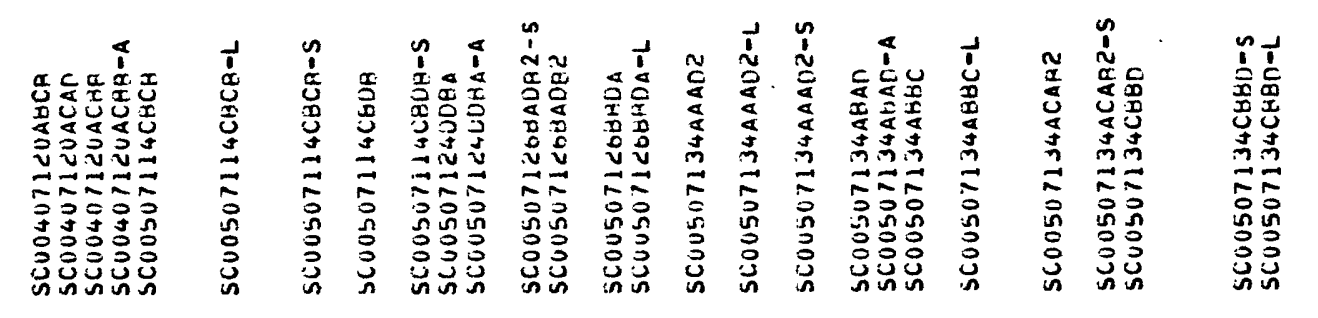

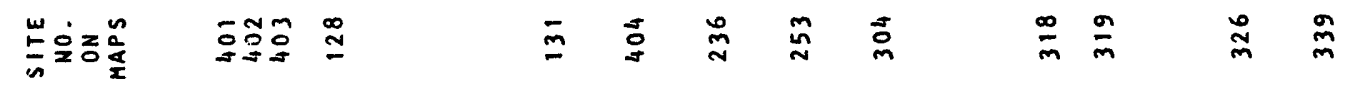




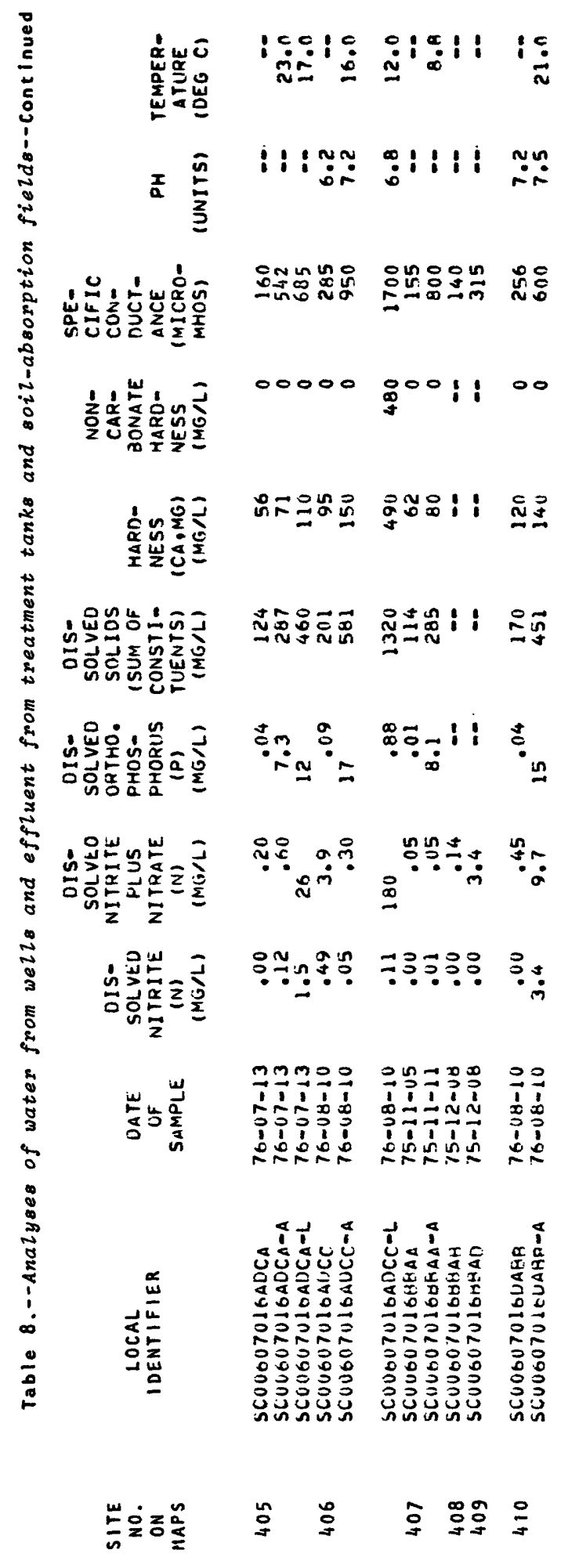




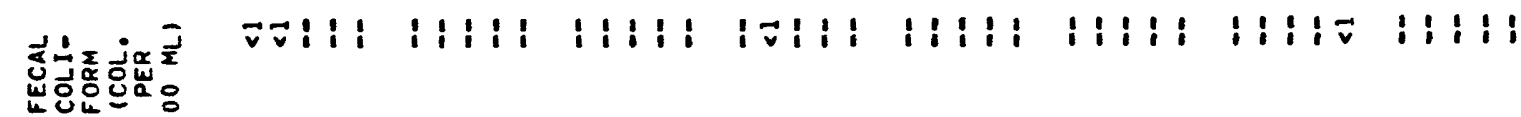

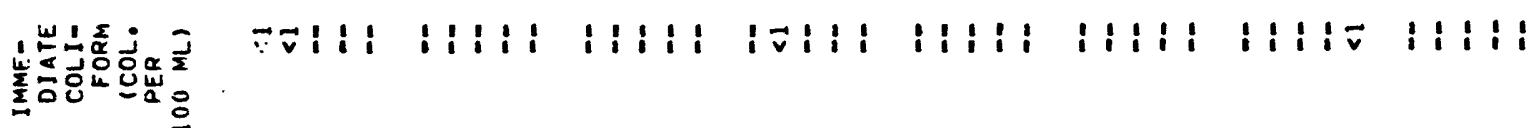
\&

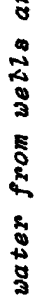

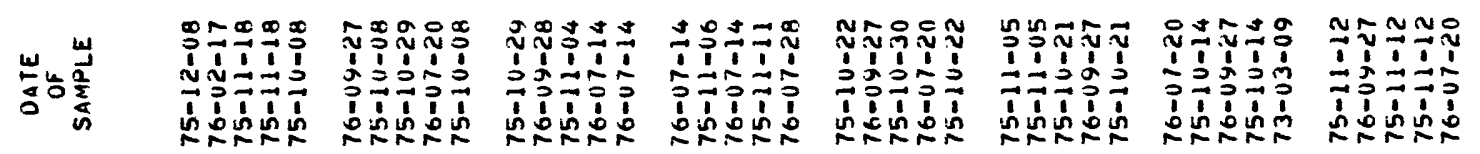

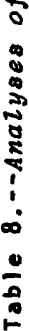
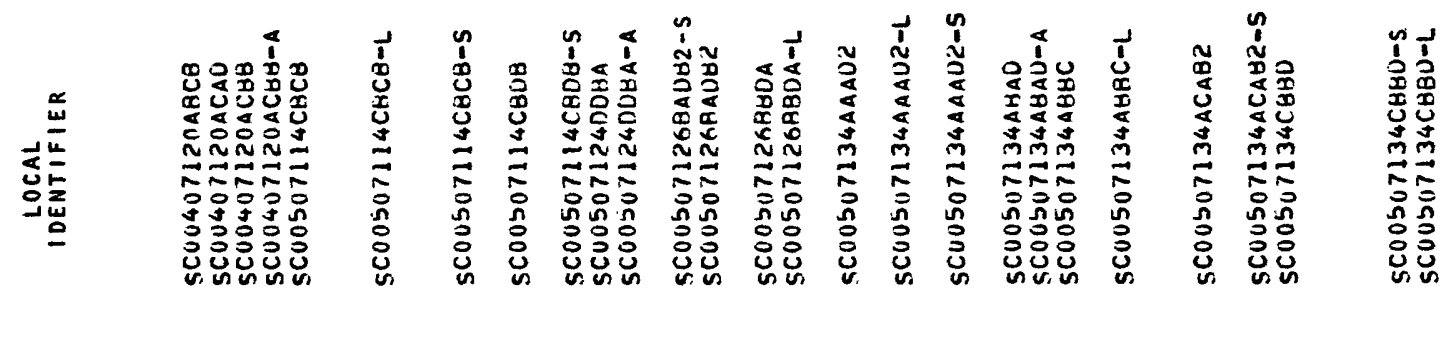

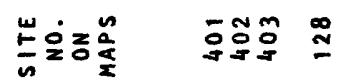

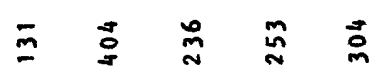

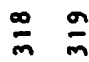

$\stackrel{\sim}{m} \underset{m}{m}$ 
$11: 11: 112011$

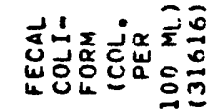

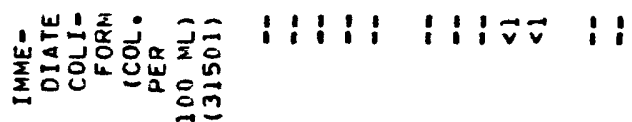
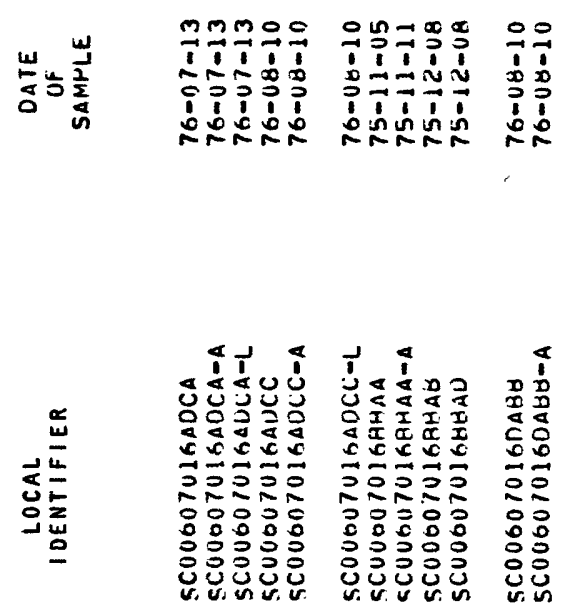

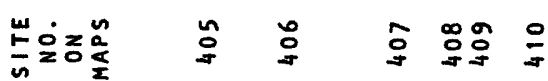



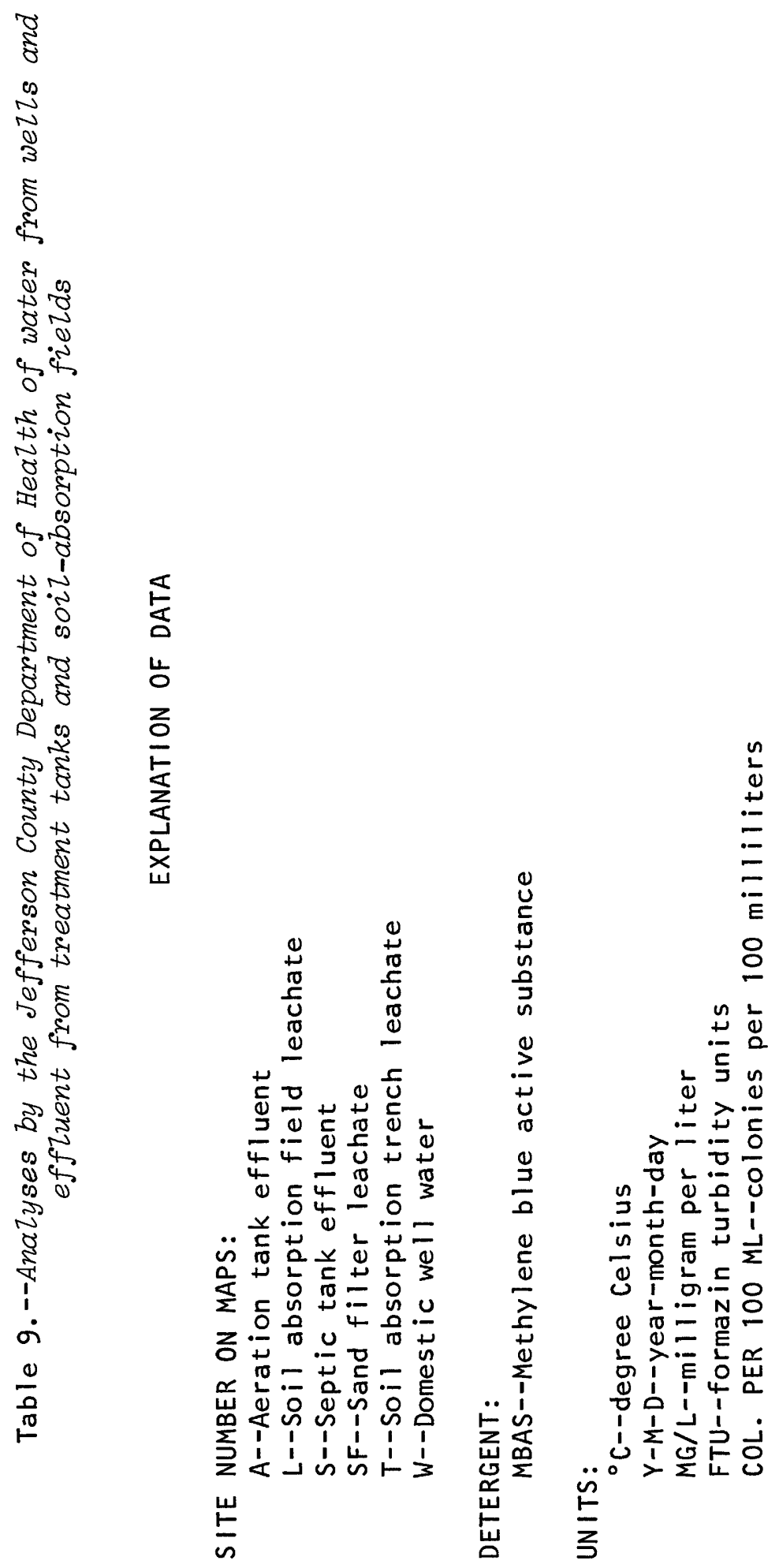


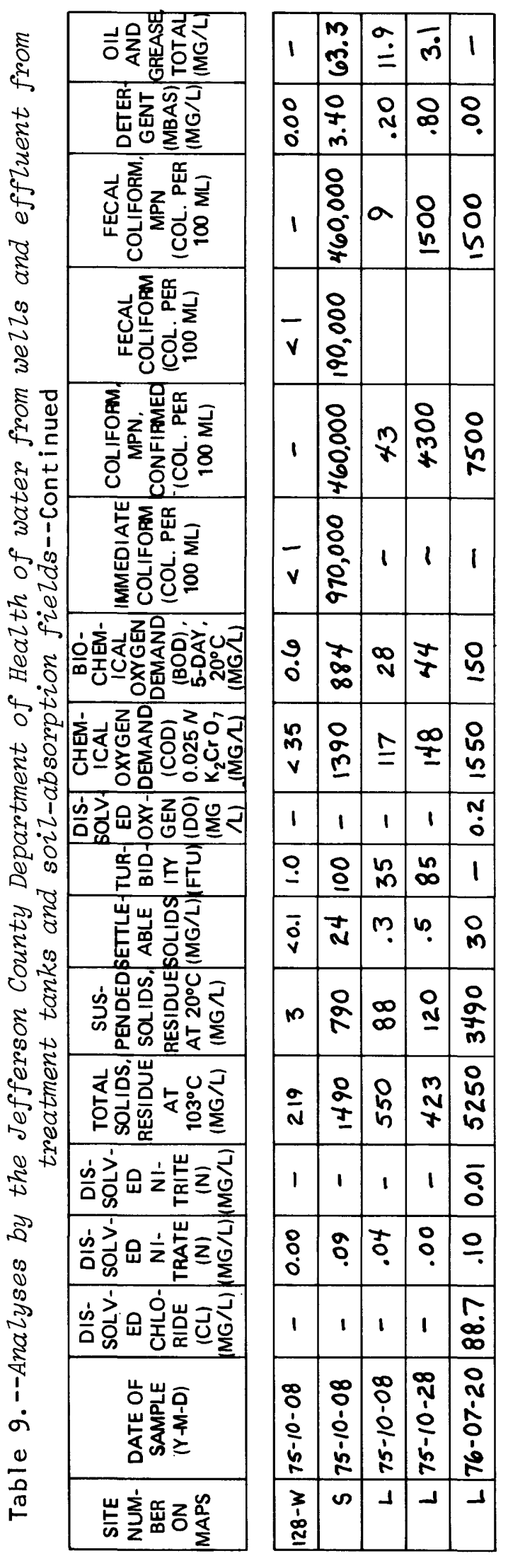

\begin{tabular}{|c|c|c|}
\hline & $1 \mid \begin{array}{l}1 \\
\underline{\underline{w}}\end{array}$ & \\
\hline 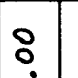 & $1 \%$ & 8 \\
\hline 1 & : & 1 \\
\hline & -18 & 1 \\
\hline
\end{tabular}

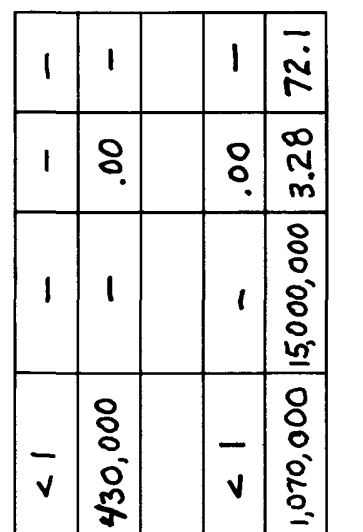

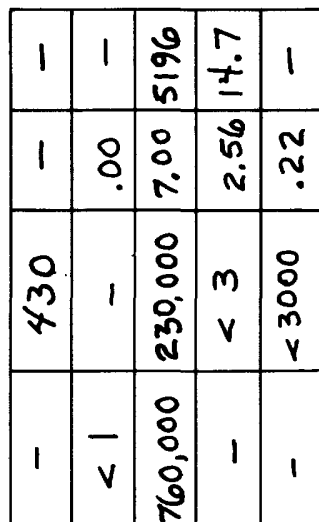

\begin{tabular}{|l|l|l|l|}
\hline 1 & 1 & $:$ & \\
\hline & & 1 \\
\hline
\end{tabular}

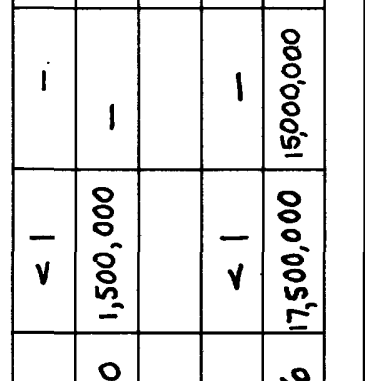

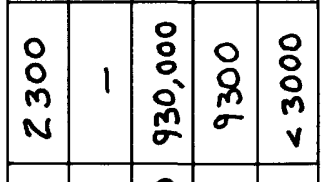

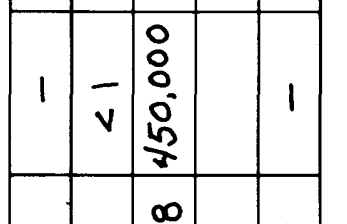

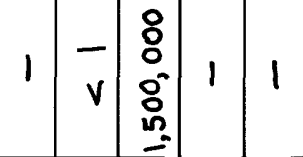

\begin{tabular}{|c|c|}
\hline 1 & \\
\hline
\end{tabular}

\begin{tabular}{|c|c|c|c|}
\hline 1 & b & 1 & 象 \\
\hline 1 & $\bar{F}$ & 1 & $\begin{array}{l}0 \\
\stackrel{2}{*} \\
\text { N }\end{array}$ \\
\hline 1 & ? & 1 & 1 \\
\hline 1 & 1 & $?$ & 운 \\
\hline 1 & ? & $\vec{v}$ & ? \\
\hline
\end{tabular}

\begin{tabular}{|c|c|c|c|}
\hline & 19 & & \\
\hline $\mathbf{v}$ & & & 2 \\
\hline
\end{tabular}

\begin{tabular}{|c|c|c|c|}
\hline f & 1 & $\begin{array}{l}\infty \\
0 \\
m\end{array}$ & 1 \\
\hline$\overline{\overrightarrow{6}}$ & 1 & 1 & $\bar{T}^{\circ}$ \\
\hline $\begin{array}{c}n \\
\tilde{i} \\
\sim\end{array}$ & 1 & $\begin{array}{l}n \\
\sigma \\
\end{array}$ & 1 \\
\hline$\vec{v}$ & 1 & $?$ & $\bar{v}$ \\
\hline
\end{tabular}

इ $1 \quad \begin{array}{lll}0 & n & 0 \\ a & N & 0 \\ n & m & \underline{w} \\ n & \end{array}$

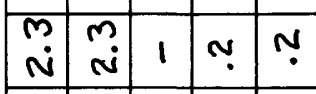

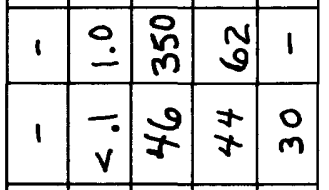

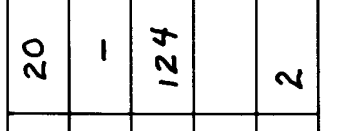

\begin{tabular}{|c|c|c|c|c|c|c|c|c|c|c|c|c|}
\hline & 1 & $\begin{array}{l}\underset{N}{N} \\
\underline{1}\end{array}$ & $v$ & 1 & $\tilde{\sigma}$ & 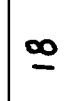 & $\begin{array}{l}\infty \\
n \\
n\end{array}$ & $\begin{array}{l}0 \\
0 \\
0 \\
i \\
r\end{array}$ & $\sigma$ & $\stackrel{R}{R}$ & & $\frac{2}{\not{7}}$ \\
\hline & 1 & $\begin{array}{l}\sigma \\
b\end{array}$ & $\underline{m}$ & 1 & $\begin{array}{c}\tilde{O} \\
\text { in }\end{array}$ & $\stackrel{m}{N}$ & $\begin{array}{l}N \\
\tilde{\sigma} \\
\sigma\end{array}$ & 1 & $\hat{x}$ & $\begin{array}{l}8 \\
: \\
\end{array}$ & $\frac{8}{9}$ & 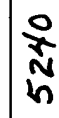 \\
\hline & 1 & 1 & 8 & 1 & : & 1 & 1 & $\because$ & 1 & 1 & 1 & $\overline{0}$ \\
\hline $\begin{array}{l}\hat{s} \\
\dot{m}\end{array}$ & 1 & : & جو & 1 & $\cong$ & 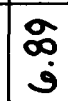 & $\because$ & $\frac{7}{\dot{v}}$ & 8 & : & $\stackrel{N}{N}$ & 음 \\
\hline
\end{tabular}

\begin{tabular}{|l|l|l|l|l|}
\hline 1 & 1 & 1 & & $\bar{i}$ \\
\hline
\end{tabular}

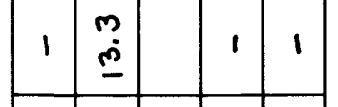

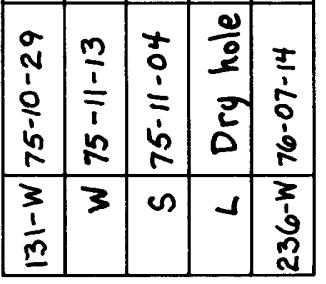

\begin{tabular}{|c|c|c|c|c|}
\hline $\bar{\Omega}$ & $₹$ & & & \\
\hline$\stackrel{0}{0}$ & $\dot{b}$ & $\stackrel{8}{8}$ & $\overline{\bar{z}}$ & $\stackrel{\bar{\prime}}{\bar{\prime}}$ \\
\hline$\theta^{2}$ & $?$ & 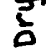 & $i$ & h \\
\hline 3 & $n$ & \lrcorner & 雍 & $n$ \\
\hline
\end{tabular}

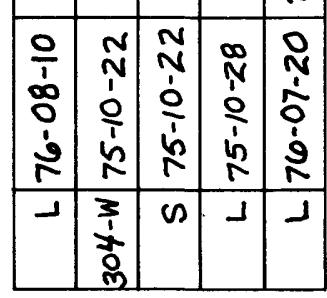




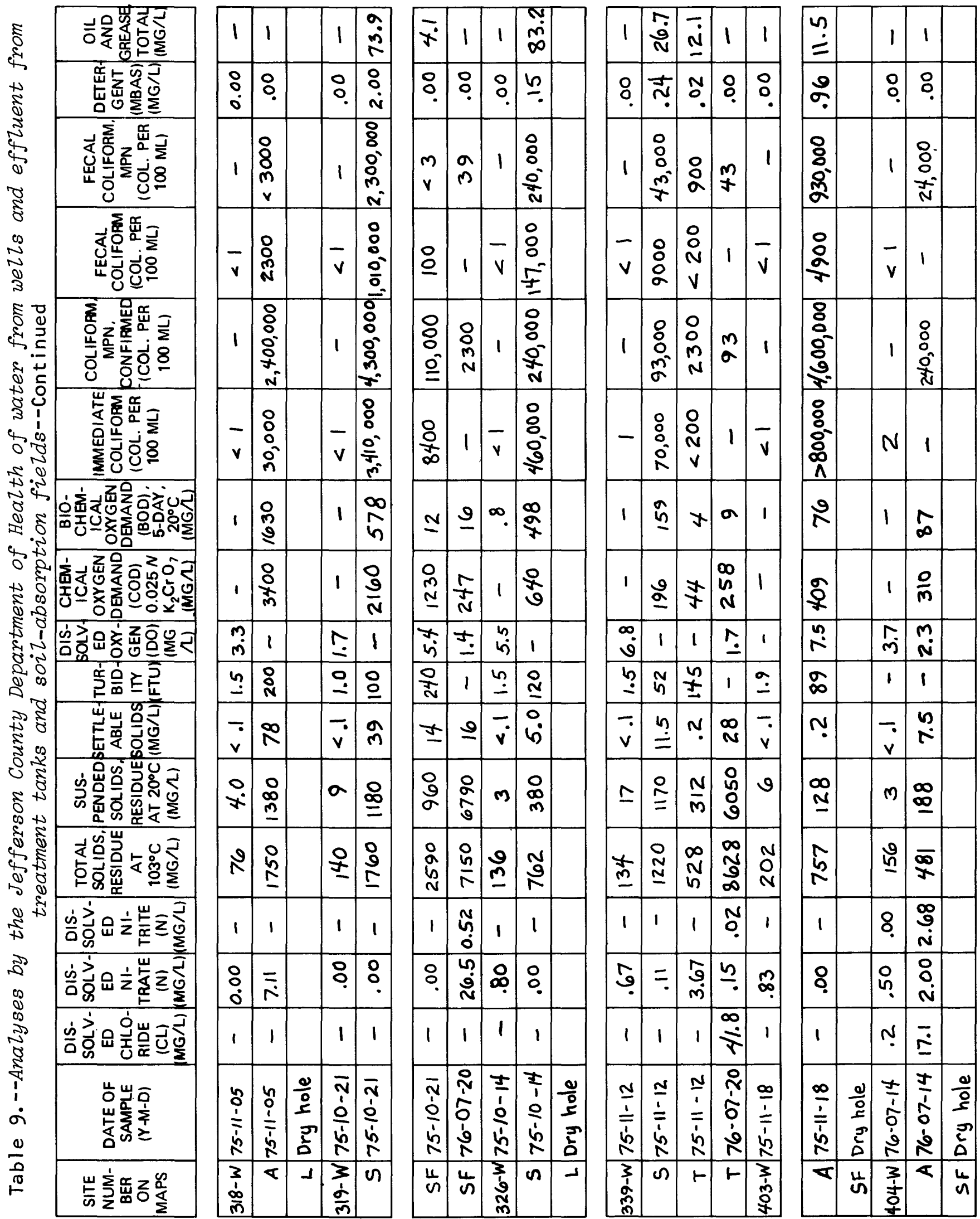



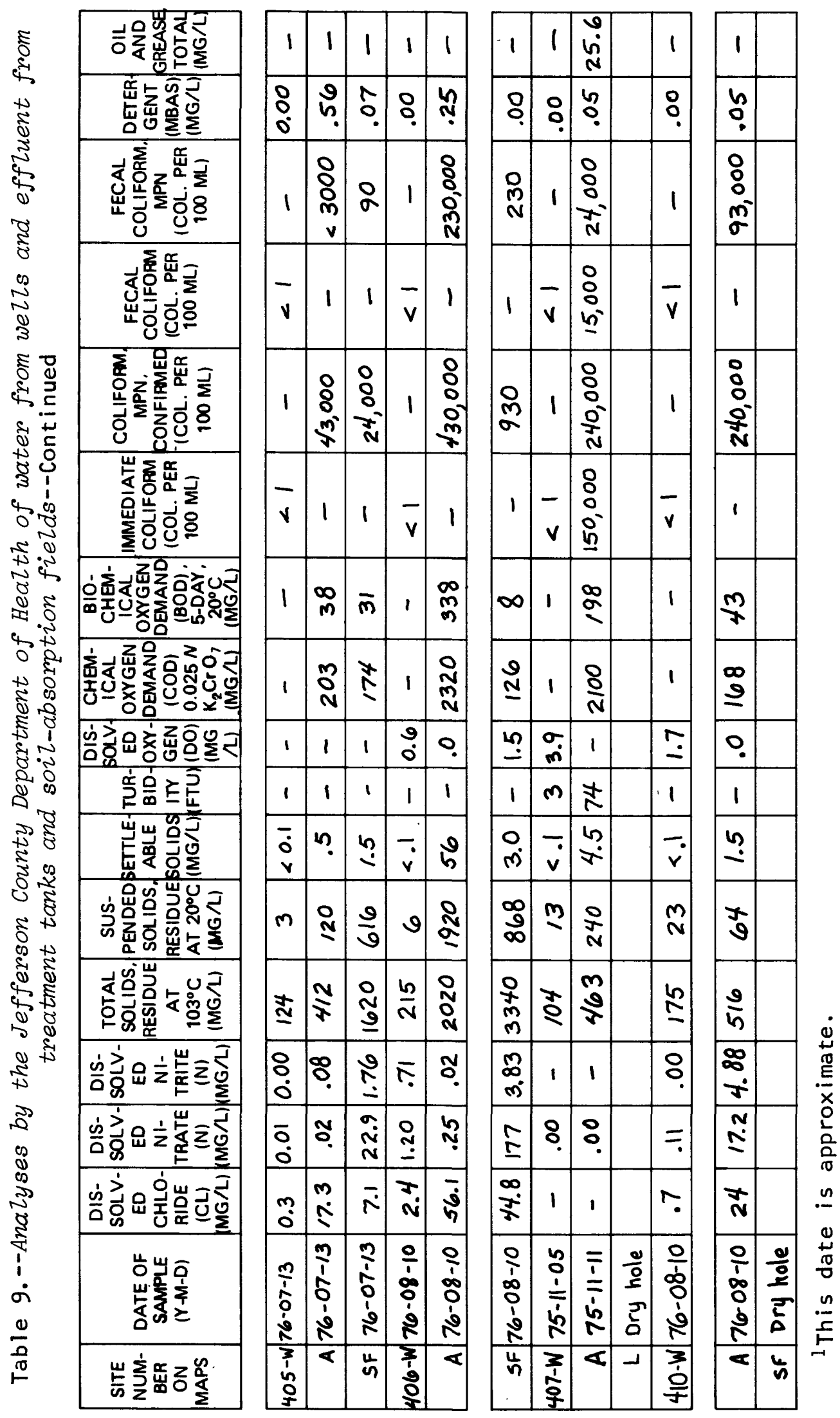

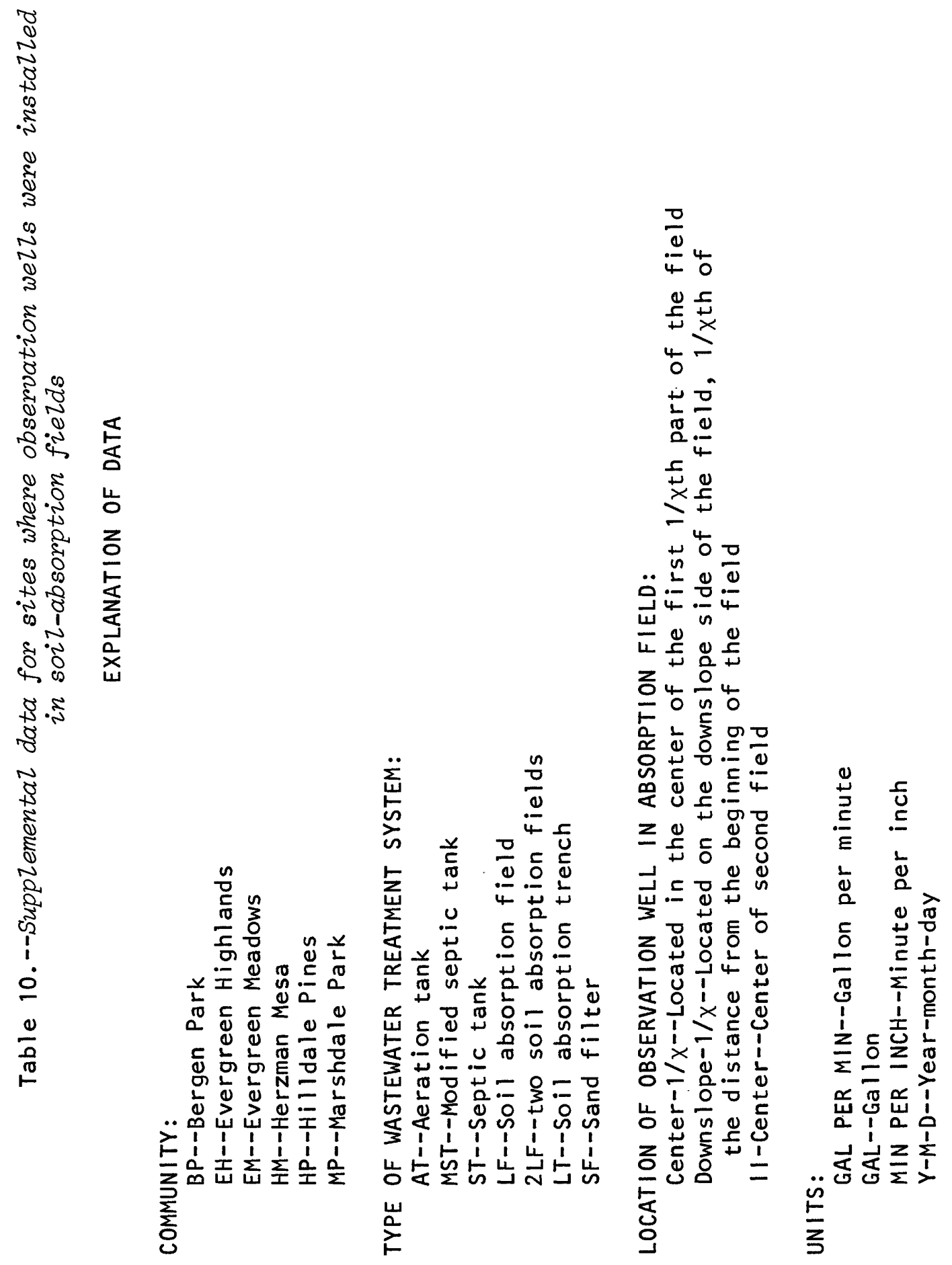


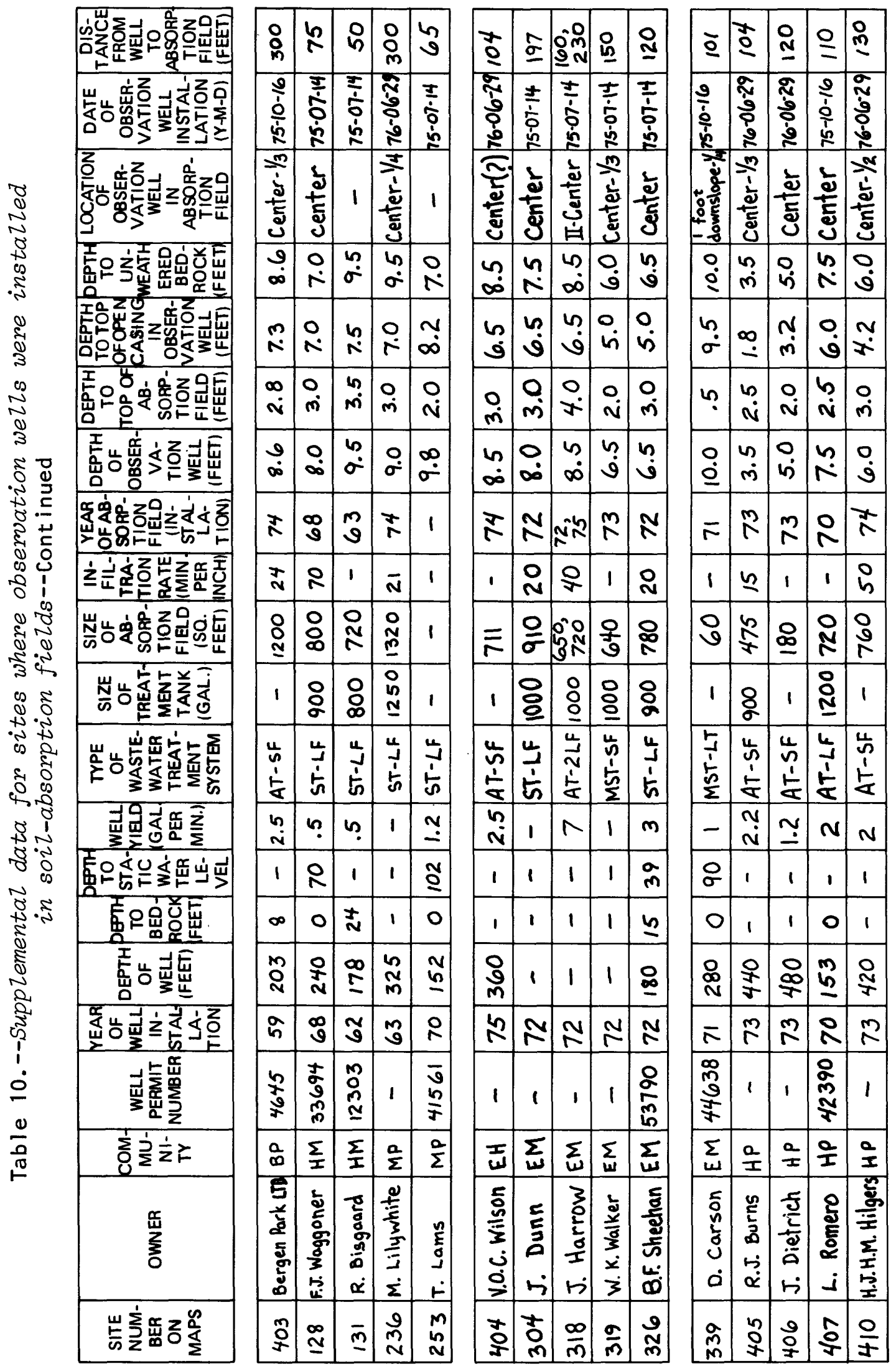


